eLIFE - Research Article

\title{
Presynaptic NMDA receptors facilitate short-term plasticity and BDNF release at hippocampal mossy fiber synapses
}

\author{
Pablo J. Lituma ${ }^{1}$, Hyung-Bae Kwon ${ }^{1,4}$, Karina Alviña ${ }^{1,5}$, Rafael Lujan ${ }^{3}$, Pablo E. Castillo ${ }^{1,2 *}$ \\ ${ }^{1}$ Dominick P. Purpura Department of Neuroscience, Albert Einstein College of Medicine, Bronx, NY \\ 10461, U.S.A. \\ ${ }^{2}$ Department of Psychiatry and Behavioral Sciences, Albert Einstein College of Medicine, Bronx, NY \\ 10461, U.S.A. \\ ${ }^{3}$ Instituto de Investigación en Discapacidades Neurológicas (IDINE), Facultad de Medicina, Universidad \\ Castilla-La Mancha, 02008 Albacete, Spain. \\ ${ }^{4}$ Present address: The Solomon H. Snyder Department of Neuroscience, John Hopkins University, \\ School of Medicine, Baltimore, MD 21205, U.S.A. \\ ${ }^{5}$ Present address: Department of Neuroscience, University of Florida, 1149 Newell Drive, Room L1-100, \\ Gainesville, FL, 32611, U.S.A.
}

Running title: Role of presynaptic NMDA receptors in short-term plasticity

Keywords: CA3, ionotropic, hippocampus, presynaptic calcium, autoreceptors

* To whom correspondence should be addressed:

Pablo E. Castillo, MD/PhD

Dominick P. Purpura Department of Neuroscience

Albert Einstein College of Medicine

1410 Pelham Parkway South

Kennedy Center, Room 703

Bronx, NY 10461, USA

Email: pablo.castillo@einsteinmed.org

Funding sources: This work supported by the NIH (F31-MH109267 to PJL; R01 MH116673, R01MH125772, and R01 NS 113600 to P.E.C.) and by the Spanish Ministerio de Economia y Competitividad (RTI2018-095812-B-I00) and Junta de Comunidades de Castillo-La Mancha (SBPLY/17/180501/000229) to RL.

Acknowledgements: We thank all the Castillo lab members for invaluable discussions. We also thank Dr. Hyungju Park for his generous gift of the BDNF-phluorin DNA construct, Dr. Michael Higley for sharing Grin1 floxed mice, and Dr. Pascal Kaeser for his generous gift of the Cre-dependent ChIEF DNA construct.

Title: 112 characters (with spaces)

Summary: 138 words, 1080 characters with spaces

Main text (excluding Summary, Methods, references and figure legends): 4,490

Figures: 8

Supplementary figures: 12 


\section{Summary}

59 Neurotransmitter release is a highly controlled process by which synapses can critically regulate

60 information transfer within neural circuits. While presynaptic receptors -typically activated by

61 neurotransmitters and modulated by neuromodulators- provide a powerful way of fine-tuning

62 synaptic function, their contribution to activity-dependent changes in transmitter release remains

63 poorly understood. Here, we report that presynaptic NMDA receptors (preNMDARs) at mossy

64 fiber boutons in the rodent hippocampus can be activated by physiologically relevant patterns of

65 activity and selectively enhance short-term synaptic plasticity at mossy fiber inputs onto CA3

66 pyramidal cells and mossy cells, but not onto inhibitory interneurons. Moreover, preNMDARs

67 facilitate brain-derived neurotrophic factor (BDNF) release and contribute to presynaptic calcium

68 rise. Taken together, our results indicate that by increasing presynaptic calcium, preNMDARs

69 fine tune mossy fiber neurotransmission and can control information transfer during dentate

70 granule cell burst activity that normally occur in vivo.

71

72

73

74

75 


\section{Introduction}

80 Neurotransmission is a dynamic and highly regulated process. The activation of ionotropic and

81 metabotropic presynaptic autoreceptors provides a powerful way of fine-tuning

82 neurotransmission via the facilitation or inhibition of neurotransmitter release (Burke \& Bender,

83 2019; Engelman \& MacDermott, 2004; Miller, 1998; Pinheiro \& Mulle, 2008; Schicker et al.,

84 2008). Due to their unique functional properties, including high calcium-permeability, slow

85 kinetics and well-characterized role as coincidence-detectors (Cull-Candy et al., 2001; Lau \&

86 Zukin, 2007; Paoletti et al., 2013; Traynelis et al., 2010), presynaptic NMDA receptors

87 (preNMDARs) have received particular attention (Banerjee et al., 2016; Bouvier et al., 2015;

88 Bouvier et al., 2018; Duguid, 2013; Duguid \& Smart, 2009; Wong et al., 2020). Regulation of

89 neurotransmitter release by NMDA autoreceptors in the brain was suggested three decades ago

90 (Martin et al., 1991). Anatomical evidence for preNMDARs arose from an immuno-electron

91 microscopy study revealing NMDARs at the mossy fiber giant bouton of the monkey

92 hippocampus (Siegel et al., 1994), followed by functional studies in the entorhinal cortex

93 indicating that preNMDARs tonically increase spontaneous glutamate release and also facilitate

94 evoked release in a frequency-dependent manner (Berretta \& Jones, 1996; Woodhall et al., 95 2001). Since these early studies, although evidence for preNMDARs has accumulated

96 throughout the brain (Banerjee et al., 2016; Bouvier et al., 2018; Duguid \& Smart, 2009), the

97 presence and functional relevance of preNMDARs at key synapses in the brain have been

98 called into question (Carter \& Jahr, 2016; Duguid, 2013).

99

100 Mossy fibers (mf) - the axons of dentate granule cells (GCs) - establish excitatory synapses

101 onto proximal dendrites of CA3 pyramidal neurons, thereby conveying a major excitatory input 102 to the hippocampus proper (Amaral et al., 2007; Henze et al., 2000). This synapse displays 
uniquely robust frequency facilitation both in vitro (Nicoll \& Schmitz, 2005; Salin et al., 1996; Vyleta et al., 2016) and in vivo (Hagena \& Manahan-Vaughan, 2010; Vandael et al., 2020). The molecular basis of this short-term plasticity is not fully understood but likely relies on diverse presynaptic mechanisms that increase glutamate release (Jackman \& Regehr, 2017; Rebola et al., 2017). Short-term, use-dependent facilitation is believed to play a critical role in information

108 transfer, circuit dynamics and short-term memory (Abbott \& Regehr, 2004; Jackman \& Regehr, 109 2017; Klug et al., 2012). The mf-CA3 synapse can strongly drive the CA3 network during short 110 bursts of presynaptic activity (Chamberland et al., 2018; Henze et al., 2002; Vyleta et al., 2016;

111 Zucca et al., 2017), an effect that likely results from two key properties of this synapse, namely,

112 its strong frequency facilitation and proximal dendritic localization. In addition to CA3 pyramidal 113 neurons, mf axons establish synaptic connections with hilar mossy cells (MC) and inhibitory 114 interneurons (IN) (Amaral et al., 2007; Henze et al., 2000). These connections also display 115 robust short-term plasticity (Lysetskiy et al., 2005; Toth et al., 2000), which may contribute significantly to information transfer and dynamic modulation of the dentate gyrus (DG)-CA3

117 circuit (Bischofberger et al., 2006; Evstratova \& Toth, 2014; Lawrence \& McBain, 2003). Despite early evidence for preNMDARs at mf boutons (Siegel et al., 1994), whether these receptors modulate neurotransmission at $\mathrm{mf}$ synapses is unknown. Intriguingly, mfs contain one of the 120 highest expression levels of brain-derived neurotrophic factor, BDNF (Conner et al., 1997).

121 While preNMDARs were implicated in BDNF release at corticostriatal synapses (Park et al., 122 2014), whether putative preNMDARs impact BDNF release at mf synapses remains unexplored.

124 Here, to examine the potential presence and impact of preNMDARs at mf synapses, we utilized 125 multiple approaches, including immunoelectron microscopy, selective pharmacology for 126 NMDARs, a genetic knockout strategy to remove NMDARs from presynaptic GCs, two-photon 127 imaging of BDNF release, and presynaptic $\mathrm{Ca}^{2+}$ signals in acute rodent hippocampal slices. Our 128 findings indicate that preNMDARs contribute to mf short-term plasticity and promotes BDNF 
release likely by increasing presynaptic $\mathrm{Ca}^{2+}$. Thus, preNMDARs at $\mathrm{mfs}$ may facilitate information transfer and provide an important point of regulation in the DG - CA3 circuit by

131 regulating both glutamate and BDNF release.

\section{Results}

\section{Electron microscopy reveals presynaptic NMDA receptors at mossy fiber terminals}

136 To determine the potential localization of NMDA receptors at the $\mathrm{mf}$ terminals of the rodent

137 hippocampus, we performed electron microscopy and post-embedding immunogold labeling in rats using a validated antibody for the obligatory subunit GluN1 (Petralia et al., 1994; Siegel et al., 1994; Takumi et al., 1999; Watanabe et al., 1998). Gold particles were detected in the main body of the postsynaptic density as well as presynaptic mf terminals (Figure 1A-C). GluN1 localized in $\mathrm{mf}$ boutons in a relatively high proportion to the active zone, as compared to

142 associational-commissural (ac) synapse in the same CA3 pyramidal neuron (Figure 1D; mf, $143 \sim 32 \%$ presynaptic particles; ac, $<10 \%$ presynaptic particles; $n=3$ animals). Similar 144 quantification for AMPA receptors did not reveal presynaptic localization of these receptors in 145 either $\mathrm{mf}$ or associational commissural synapses (Figure 1-figure supplement 1; $5 \%$ 146 presynaptic particles, $n=3$ animals). Together, these results provide anatomical evidence for

147 preNMDARs at mf-CA3 synapses.

151 Presynaptic short-term plasticity, in the form of low-frequency $(\sim 1 \mathrm{~Hz})$ facilitation (LFF), is 152 uniquely robust at the mf-CA3 synapse (Nicoll \& Schmitz, 2005; Salin et al., 1996). To test a 153 potential involvement of preNMDARs in LFF, we monitored AMPAR-mediated excitatory 154 postsynaptic currents (EPSCs) from CA3 pyramidal neurons in acute rat hippocampal slices. 
155 Neurons were held at $\mathrm{V}_{\mathrm{h}}=-70 \mathrm{mV}$ to minimize postsynaptic NMDAR conductance, and mfs were

156 focally stimulated with a bipolar electrode (theta glass pipette) placed in stratum lucidum 100

$157 \mu \mathrm{m}$ from the recorded cell. LFF was induced by stepping the stimulation frequency from $0.1 \mathrm{~Hz}$

158 to $1 \mathrm{~Hz}$ for $\sim 2 \mathrm{~min}$ in the presence of picrotoxin $(100 \mu \mathrm{M})$ to block fast inhibitory synaptic

159 transmission, and a low concentration of the AMPAR noncompetitive antagonist LY303070 (0.5

$160 \mu \mathrm{M})$ to minimize CA3-CA3 recurrent activity (Kwon \& Castillo, 2008). Bath-application of the

161 NMDAR irreversible open channel blocker MK-801 $(50 \mu \mathrm{M})$ significantly reduced LFF (Figure

162 1E). In addition, the competitive NMDAR antagonists D-APV $(100 \mu M)$ or R-CPP $(50 \mu M)$

163 yielded a comparable reduction of facilitation (Figure 1F). To confirm that these synaptic 164 responses were mediated by mfs, the mGluR2/3 agonist DCG-IV $(1 \mu \mathrm{M})$ was applied at the end 165 of all recordings (Kamiya et al., 1996). To control for stability, we performed interleaved experiments in the absence of NMDAR antagonists and found that LFF remained unchanged

167 (Figure 1-figure supplement 2A). These findings indicate NMDAR antagonism reduces mf168 CA3 short-term plasticity (LFF), suggesting that preNMDARs could contribute to this form of 169 presynaptic plasticity.

171 The reduction in facilitation of AMPAR-transmission could be due to dampening of CA3 172 recurrent activity by NMDAR antagonism (Henze et al., 2000; Kwon \& Castillo, 2008; Nicoll \& 173 Schmitz, 2005). To discard this possibility, we repeated our experiments in a much less 174 excitable network in which AMPAR-mediated synaptic transmission was selectively blocked by a 175 high concentration of the noncompetitive antagonist LY303070 (15 $\mu \mathrm{M})$ and monitored the 176 kainate receptor (KAR)-mediated component of mf synaptic transmission (Castillo et al., 1997;

177 Kwon \& Castillo, 2008). In addition, 2 mM MK-801 was included in the intracellular recording 178 solution to block postsynaptic NMDARs (Corlew et al., 2008) (Figure 1-figure supplement 3). 179 To further ensure postsynaptic NMDAR blockade, we voltage-clamped the CA3 pyramidal 180 neuron at $-70 \mathrm{mV}$ and waited until NMDAR-mediated transmission was eliminated and only 
181 KAR-EPSCs remained. Under these recording conditions, bath-application of MK-801 (50 $\mu \mathrm{M})$

182 also reduced LFF of KAR-mediated transmission (Figure 1G), whereas LFF remained

183 unchanged in interleaved control experiments (Figure 1-figure supplement 2B). At the end of

184 these recordings, $10 \mu \mathrm{M}$ NBQX was applied to confirm KAR-transmission (Figure 1G; Figure 1-

185 figure supplement 2B) (Castillo et al., 1997; Kwon \& Castillo, 2008). It is therefore unlikely that

186 the reduction of LFF mediated by NMDAR antagonism could be explained by recurrent network

187 activity, suggesting a direct effect on transmitter release.

189 To further support a role of preNMDARs in mf LFF, we took a genetic approach by conditionally 190 removing NMDARs from GCs in Grin1 floxed mice. To this end, an AAV5-CamKII-Cre-GFP virus 191 was bilaterally injected in the DG to selectively delete Grin1 expression, whereas AAV5-CamKII192 eGFP was injected in littermates as a control at postnatal days 16-20 in both groups (Figure 193 2A). Two weeks after surgery, we prepared acute hippocampal slices and examined the efficacy 194 of Grin1 deletion by analyzing NMDAR-mediated transmission in GFP ${ }^{+}$GCs of Grin1-cKO and control mice. We confirmed that in contrast to control mice, no NMDAR-EPSCs were elicited by electrically stimulating medial perforant path inputs in Grin1-cKO GCs voltage-clamped at +40 $\mathrm{mV}$ in the presence of $100 \mu \mathrm{M}$ picrotoxin and $10 \mu \mathrm{M} \mathrm{NBQX}$ (Figure 2B). As expected, the NMDAR/AMPAR ratio was significantly reduced in Grin1-cKO mice compared to control (Figure 2C). Only acute slices that exhibited robust GFP fluorescence in the DG were tested for LFF of AMPAR-transmission in CA3. We found that LFF was significantly reduced in Grin1-cKOs as compared to controls (Figure 2D), indicating that genetic removal of NMDARs from GCs

202 recapitulated NMDAR antagonism (Figure 1E-G). Grin1 deletion did not affect basal transmitter 203 release as indicated by a comparable paired-pulse ratio to control (Control: $2.5 \pm 0.36, n=13$ 204 cells; Grin1 cKO: $2.4 \pm 0.31, \mathrm{n}=13$ cells; $U>0.5$, Mann-Whitney test). Collectively, our findings 205 using two distinct approaches strongly suggest that NMDAR activation in GCs increases LFF of 206 mf-CA3 synaptic transmission. 
Reduced facilitation by NMDAR antagonism is independent of the granule cell somatodendritic compartment

210 Bath application of MK-801 could have blocked dendritic NMDARs in GCs and potentially

211 affected transmitter release (Christie \& Jahr, 2008; Duguid, 2013). To address this possibility,

212 we repeated our experiments after performing a surgical cut in the granular layer of the DG in

213 order to isolate mf axons from GCs (Figure 3-figure supplement 1A). Under these conditions,

214 MK-801 bath application still reduced LFF (Figure 3A), and LFF was stable in control, acutely

215 transected axons (Figure 3B). In addition, puffing D-APV (2 mM) in stratum lucidum near ( 200

$216 \mu \mathrm{m}$ ) the recorded neuron also reduced LFF (Figure 3 C), whereas puffing ACSF had no effect

217 (Figure 3D). Lastly, in a set of control experiments, we confirmed that D-APV puffs were 218 sufficient to transiently block NMDAR-mediated transmission in CA3 but not in DG (Figure 3-

219 figure supplement $1 \mathrm{~B}, \mathbf{C})$. Together, these results support the notion that LFF reduction was 220 due to the blockade of preNMDARs but not somatodendritic NMDARs on GCs.

222 PreNMDARs boost information transfer by enhancing burst-induced facilitation at mossy

\section{3 fiber synapses}

224 GCs in vivo typically fire in brief bursts (Diamantaki et al., 2016; GoodSmith et al., 2017; Henze

225 et al., 2002; Pernia-Andrade \& Jonas, 2014; Senzai \& Buzsaki, 2017). To test whether 226 preNMDARs contribute to synaptic facilitation that occurs during more physiological patterns of

227 activity, mfs were activated with brief bursts (5 stimuli, $25 \mathrm{~Hz}$ ). We first took an optogenetic 228 approach and used a Cre-dependent ChIEF virus to selectively light-activate mf-CA3 synapses 229 in Grin1-cKO and control mice. Thus, animals were injected with a mix of AAV5-CamKII-CreGFP 230 + AAV-DJ-FLEX-ChIEF-tdTomato viruses in the DG (Figure 4A). At least four weeks after 231 surgery, acute slices were prepared and burst-induced facilitation of AMPAR-mediated 232 transmission in CA3 was assessed (Figure 4B,C). Burst-induced facilitation triggered by light 
233 stimulation and measured as the ratio of EPSCs elicited by the $5^{\text {th }}$ and $1^{\text {st }}$ pulse (P5/P1 ratio),

234 was significantly reduced in Grin1-cKO animals as compared to controls. Because these bursts

235 of activity can activate the CA3 network (Henze et al., 2000; Kwon \& Castillo, 2008; Nicoll \&

236 Schmitz, 2005), we next monitored KAR-EPSCs under conditions of low excitability (as in Figure

237 1G). MK-801 bath application also reduced burst-induced facilitation, whereas facilitation

238 remained unchanged in naïve slices (Figure 4D,E). In a separate set of experiments, we

239 confirmed the reduction of MK-801 on burst-induced facilitation under more physiological

240 recording conditions (Figure 4-figure supplement 1). Lastly, we tested whether preNMDARs,

241 by facilitating glutamate release during bursting activity, could bring CA3 pyramidal neurons to

242 threshold and trigger postsynaptic action potentials. To test this possibility, we monitored action

243 potentials elicited by KAR-EPSPs (resting membrane potential $-70 \pm 2 \mathrm{mV}$ ) from CA3 pyramidal

244 neurons intracellularly loaded with 2 mM MK-801. Under these recording conditions, MK-801

245 bath application significantly reduced the mean number of spikes per burst (Figure 4F). No

246 changes in mean spikes per burst were observed in naïve slices over time (Figure 4G).

247 Application of $10 \mu \mathrm{M} N B Q X$ at the end of these experiments confirmed that action potentials

248 were induced by KAR-mediated synaptic responses. Consistent with these observations, MK-

249801 also reduced the mean number of spikes per burst when AMPAR-mediated action

250 potentials were recorded from CA3 pyramidal neurons (Figure 4-figure supplement 2). In

251 control experiments, we found that intracellular MK-801 effectively blocked postsynaptic

252 NMDAR transmission during burst stimulation (Figure 4-figure supplement 3). Altogether,

253 these results indicate that preNMDARs at mf-CA3 synapses can contribute to information

254 transfer from the DG to CA3.

257 PreNMDARs contribute to presynaptic calcium rise and can be activated by glutamate

258 PreNMDARs could facilitate glutamate and BDNF release by increasing presynaptic $\mathrm{Ca}^{2+}$ rise 
259 (Bouvier et al., 2016; Buchanan et al., 2012; Corlew et al., 2008; Park et al., 2014). To test this

260 possibility at mf-CA3 synapses, we combined a conditional knockout strategy with $\mathrm{Ca}^{2+}$ imaging

261 using two-photon laser scanning microscopy. We first deleted preNMDARs by injecting AAV5-

262 CamKII-mCherry-Cre virus in the DG of Grin1 floxed mice, and littermate animals injected with

263 AAV5-CamKII-mCherry virus served as control (Figure 5A). Two weeks after surgery, we

264 confirmed the efficacy of Grin1 deletion by activating medial perforant path inputs and

265 monitoring NMDAR/AMPAR ratios in GCs of control and Grin1-cKO animals (Figure 5A).

266 Virtually no NMDAR-EPSCs were detected at $\mathrm{V}_{\mathrm{h}}=+40 \mathrm{mV}$ in Grin1-cKO animals (Figure 5A).

267 Acute slices that exhibited robust mCherry fluorescence in the DG were used for $\mathrm{Ca}^{2+}$ imaging

268 experiments. To maximize our ability to detect preNMDAR-mediated $\mathrm{Ca}^{2+}$ signals, we used a

269 recording solution that contained $0 \mathrm{mM} \mathrm{Mg}^{2+}, 4 \mathrm{mM} \mathrm{Ca}^{2+}$ and $10 \mu \mathrm{M}$ D-Serine (Carter \& Jahr,

270 2016). GCs expressing mCherry were patch-loaded with $35 \mu \mathrm{M}$ Alexa 594 (used as

271 morphological dye) and $200 \mu \mathrm{M}$ Fluo-5F, and mf axons were imaged and followed towards CA3

272 until giant boutons (white arrows) were identified (Figure 5B). We found that $\mathrm{Ca}^{2+}$ transients

273 (CaTs) elicited by direct current injection in the GC soma (5 action potentials, $25 \mathrm{~Hz}$ ) were

274 significantly smaller in Grin1-cKO animals as compared to control (Figure 5C-E). In addition,

275 NMDAR antagonism with D-APV reduced presynaptic $\mathrm{Ca}^{2+}$ rise even under more physiological

$276 \mathrm{Mg}^{+2}$ concentration in acute rat hippocampal slices (Figure 5-figure supplement 1). Thus,

277 preNMDARs contribute significantly to presynaptic $\mathrm{Ca}^{2+}$ rise in $\mathrm{mf}$ boutons, and by this means

278 likely facilitates synaptic transmission, although a potential contribution of $\mathrm{Ca}^{2+}$ rise-independent

279 effects cannot be discarded.

281 Lastly, we sought to determine if direct activation of preNMDARs could drive $\mathrm{Ca}^{2+}$ influx in mf 282 giant boutons. To test this possibility, we elicited CaTs by two-photon glutamate uncaging (2PU)

283 on $\mathrm{mf}$ boutons of control and Grin1-cKO animals (Figure 6A). As previously described, 284 mCherry GCs were patch-loaded with Alexa 594 and Fluo-5F in a recording solution designed to 
maximize the detection of preNMDAR-mediated $\mathrm{Ca}^{2+}$ signals (as in Figure 5). We first confirmed that glutamate 2PU-induced CaTs in dendritic spine heads of GCs were strongly reduced in Grin1-cKO animals as compared to controls (Figure 6B,C). To verify that reduced $\mathrm{Ca}^{2+}$ signals $(\Delta \mathrm{G} / \mathrm{R})$ were a result of Grin1 deletion and not differences in uncaging laser power, we performed a laser power intensity-response curve, and found that Grin1-cKO animals exhibited reduced $\Delta \mathrm{G} / \mathrm{R}$ signals as compared to control regardless of laser power intensity (Figure 6-figure supplement 1). We next measured glutamate 2PU-induced CaTs in mf giant boutons (identified as in Figure 5B) and found that single uncaging pulses were insufficient to

293 drive detectable CaTs in control boutons (Figure 6-figure supplement 2). However, a burst of 294 2PU stimulation (5 pulses, $25 \mathrm{~Hz}$ ) induced CaTs in mf boutons of control but not in Grin1-cKO 295 animals (Figure 6D,E). Additionally, CaTs elicited by 2PU stimulation were abolished by D-APV application (Figure 6-figure supplement 3). These findings indicate that brief bursts of glutamate 2PU, a manipulation that mimics endogenous release of glutamate during physiological patterns of activity, induces presynaptic $\mathrm{Ca}^{2+}$ influx in $\mathrm{mf}$ boutons by activating preNMDARs.

PreNMDARs promote BDNF release from mossy fiber boutons

302 Previous work implicated preNMDARs in the release of BDNF at corticostriatal synapses 303 following burst stimulation and presynaptic $\mathrm{Ca}^{2+}$ elevations (Park et al., 2014). Given the high 304 expression levels of BDNF in mfs (Conner et al., 1997; Yan et al., 1997), we examined the 305 potential role for preNMDARs in BDNF release from mf terminals. To this end, a Cre-dependent 306 BDNF reporter (BDNF-pHluorin) was injected in Grin1-floxed and control animals. Littermate 307 mice were injected with a mix of AAV5-CamKII-mCherry-Cre + AAV-DJ-DIO-BDNF-pHluorin 308 viruses in the DG (Figure 7A). At least four weeks after surgery, acute slices were prepared for 309 two-photon laser microscopy to image mf boutons. After acquiring a stable baseline of BDNF310 pHluorin signals, mfs were repetitively activated (see Methods) (Figure 7B). BDNF-pHluorin 
311 signals were analyzed by measuring $\Delta \mathrm{F} / \mathrm{F}$, where $\Delta \mathrm{F} / \mathrm{F}$ reductions indicate BDNF release (Park

312 et al., 2014). We found that GluN1-deficient mf boutons showed a significant ( 50\%)

313 impairment in BDNF release as compared to control (Figure 7C-D). Furthermore, using a more

314 physiological pattern of burst stimulation, GluN1-lacking mf boutons still displayed altered BDNF

315 release as compared to control (Figure 7-figure supplement 1). Taken together, our results

316 suggest preNMDARs contribute significantly to BDNF release during repetitive or burst

317 stimulation of $\mathrm{mf}$ synapses.

319 PreNMDAR-mediated regulation of mossy fiber synapses is input-specific

320 In addition to providing a major excitatory input to the hippocampus proper, mf axons also 321 synapse onto excitatory hilar mossy cells and inhibitory neurons in CA3 (Amaral et al., 2007;

322 Henze et al., 2000; Lawrence \& McBain, 2003). To test whether preNMDARs could also play a 323 role at these synapses, we visually patched mossy cells and interneurons in acute rat 324 hippocampal slices, loaded them with $35 \mu \mathrm{M}$ Alexa 594 (Figure 8A) and 2 mM MK-801, and 325 monitored AMPAR-EPSCs $\left(\mathrm{V}_{\mathrm{h}}=-70 \mathrm{mV}\right)$. Unlike mf-CA3 synapses, $\mathrm{mf}$ synapses onto CA3 326 interneurons in stratum lucidum do not express LFF, but can undergo burst-induced facilitation 327 or depression (Toth et al., 2000). We found that MK-801 bath application had no effect on burst328 induced facilitation or depression (Figure 8B), suggesting preNMDARs do not play a role at mf329 Interneuron synapses in CA3. Mf inputs onto hilar mossy cells undergo robust activity330 dependent facilitation (Lysetskiy et al., 2005). Similar to mf-CA3 synapses, we found that MK331801 reduced LFF (Figure $\mathbf{8 C}$ ). Stability experiments of $\mathrm{mf}$ transmission at CA3 interneurons or 332 hilar mossy cells showed no significant differences (Figure 8-figure supplement 1). Taken 333 together, our findings demonstrate that preNMDARs facilitate mf transmission onto excitatory 334 neurons but not onto inhibitory interneurons. 


\section{Discussion}

In this study, we provide evidence that hippocampal mf boutons express preNMDARs whose activation fine-tunes $\mathrm{mf}$ synaptic function. Specifically, our results show that preNMDARs

341 enhance $\mathrm{mf}$ short-term plasticity in a target cell-specific manner. By enhancing glutamate

342 release onto excitatory but not inhibitory interneurons, preNMDARs increase GC-CA3 spike

343 transfer. Moreover, using two-photon $\mathrm{Ca}^{2+}$ imaging, we demonstrate that preNMDARs contribute

344 to presynaptic $\mathrm{Ca}^{2+}$ rise in mf boutons. Lastly, upon repetitive activity, preNMDARs promote

345 BDNF release from mf boutons. Taken together, our findings indicate that preNMDARs act as

346 autoreceptors to boost both glutamate and BDNF release at $\mathrm{mf}$ synapses. By regulating

347 information flow in the DG-CA3 circuit, preNMDARs may play a significant role in learning and

348 memory.

350 Early studies using immunoperoxidase electron microscopy revealed NMDARs in presynaptic

351 compartments in multiple brain areas (for a review, see Corlew et al., 2008). Subsequent

352 studies that used immunogold electron microscopy, a more precise localization method,

353 identified NMDARs on the presynaptic membrane in a number of brain structures, including

354 neocortex (Fujisawa \& Aoki, 2003; Larsen et al., 2011), hippocampus (Berg et al., 2013;

355 Jourdain et al., 2007; McGuinness et al., 2010), and amygdala (Pickel et al., 2006). In

356 agreement with these studies, and using a previously validated antibody (Siegel et al., 1994),

357 we identified prominent presynaptic labeling of the obligatory subunit GluN1 in mf boutons

358 (Figure 1A-D). Moreover, we found that these receptors are close to the active zone and

359 therefore well positioned to modulate neurotransmitter release.

361 Previous work in the cerebellum and neocortex suggested that somatodendritic potentials 362 generated by NMDARs could signal to nerve terminals and lead to presynaptic $\mathrm{Ca}^{2+}$ elevations 
363 (Christie \& Jahr, 2008, 2009). Thus, changes in neurotransmitter release resulting from NMDAR 364 antagonism could be due to somatodendritic NMDARs but not necessarily preNMDARs residing 365 on nerve terminals (Duguid, 2013). However, we showed that focal NMDAR antagonism far 366 from the somatodendritic compartment and in transected axons still reduced short-term 367 plasticity at mf synapses (Figure 3), making it extremely unlikely that somatodendritic NMDARs 368 could explain our results. In further support of functional preNMDARs at mf boutons, we found 369 that 2PU of glutamate induced $\mathrm{Ca}^{2+}$ rise in control but not in GluN1-deficient boutons. Together, 370 our findings strongly support the presence of functional preNMDARs facilitating 371 neurotransmission at mf-CA3 synapses.

373 There is evidence that preNMDARs can operate as coincidence detectors at some synapses 374 (Duguid, 2013; Wong et al., 2020). At the mf-CA3 synapse, we found that preNMDARs 375 contribute to LFF (i.e. 1s inter-stimulus interval). This observation is intriguing given that the 376 presynaptic AP-mediated depolarization is likely absent by the time glutamate binds to 377 preNMDARs. However, coincidence detection may not be an essential requirement for mf 378 preNMDARs to modulate glutamate release. Of note, at resting membrane potential the 379 NMDAR conductance is not zero and the driving force for $\mathrm{Ca}^{2+}$ influx is high (Paoletti et al., 380 2013; Traynelis et al., 2010). It is also conceivable that mf preNMDARs exhibit low-voltage 381 dependence, as it has been reported at other synapses (Wong et al., 2020). Remarkably, the 382 somatodendritic compartment of GCs can generate sub-threshold depolarizations at $\mathrm{mf}$ 383 terminals (a.k.a. excitatory presynaptic potentials) (Alle \& Geiger, 2006). By alleviating the 384 magnesium blockade, these potentials might reduce the need for coincidence detection and 385 transiently boost the functional impact of mf preNMDARs.

387 While the presence of preNMDARs is downregulated during development both in neocortex 388 (Corlew et al., 2007; Larsen et al., 2011) and hippocampus (Mameli et al., 2005), we were able 
to detect functional preNMDARs in young adult rats (P17-P28) and mice (P30-P44), once mf connections are fully developed (Amaral \& Dent, 1981). Functional preNMDARs have been identified in axonal growth cones of hippocampal and neocortical neurons, suggesting these receptors are important for regulating early synapse formation (Gill et al., 2015; Wang et al., 2011). Because GCs undergo adult neurogenesis, and adult born GCs establish new connections in the mature brain, preNMDARs could also play an important role at immature mf synapses and functional integration of new born GCs into the mature hippocampus (Toni \& 396 Schinder, 2015). Moreover, experience can modulate the expression and composition of 397 preNMDARs in neocortex (Larsen et al., 2014), a possibility not investigated in our study.

The glutamate that activates preNMDARs may originate from the presynaptic terminal, the 400 postsynaptic cell, nearby synapses or neighboring glial cells. Our results indicate that activation 401 of preNMDARs at $\mathrm{mf}$ synapses requires activity-dependent release of glutamate that likely 402 arises from mf boutons, although other sources cannot be discarded, including astrocytes. For 403 instance, at medial entorhinal inputs to GCs, preNMDARs appear to be localized away from the 404 presynaptic release sites and facing astrocytes, consistent with preNMDAR activation by 405 gliotransmitters (Jourdain et al., 2007; Savtchouk et al., 2019). In contrast, at mf-CA3 synapses 406 we found that preNMDARs are adjacent to the release sites suggesting a direct control on 407 glutamate release from mf boutons.

409 The precise mechanism by which preNMDARs facilitate neurotransmitter release is poorly 410 understood but it may include $\mathrm{Ca}^{2+}$ influx through the receptor and depolarization of the 411 presynaptic terminal with subsequent activation of voltage-gated $\mathrm{Ca}^{2+}$ channels (Banerjee et al., 412 2016; Corlew et al., 2008). In support of this mechanism is the high $\mathrm{Ca}^{2+}$ permeability of 413 NMDARs (Paoletti et al., 2013; Rogers \& Dani, 1995). Besides, presynaptic subthreshold 414 depolarization and subsequent activation of presynaptic voltage-gated $\mathrm{Ca}^{2+}$ channels is a 
415 common mechanism by which presynaptic ionotropic receptors facilitate neurotransmitter

416 release (Engelman \& MacDermott, 2004; Pinheiro \& Mulle, 2008). PreNMDARs may also act in

417 a metabotropic manner (Dore et al., 2016) and facilitate spontaneous transmitter release

418 independent of $\mathrm{Ca}^{2+}$-influx (Abrahamsson et al., 2017). Our findings demonstrating that the

419 open channel blocker MK-801 robustly reduced short-term plasticity at mf synapses support an

420 ionotropic mechanism that involves $\mathrm{Ca}^{2+}$ influx through preNMDARs. A previous study failed to

421 observe $\mathrm{Ca}^{+2}$ reductions in mf boutons by DL-APV (Liang et al., 2002). A combination of factors

422 could account for this discrepancy with our study, including a stronger mf repetitive stimulation

423 (20 pulses, $100 \mathrm{~Hz}$ ) which may overcome a less potent NMDAR antagonism and/or the need for

424 preNMDAR activity, as well as the use of a higher affinity $\mathrm{Ca}^{2+}$ indicator (Fura-2 AM) and a lower

425 spatiotemporal resolution imaging approach. Nevertheless, in line with previous studies that

426 detected presynaptic $\mathrm{Ca}^{2+}$ rises following local activation of NMDARs (e.g. NMDA or glutamate

427 uncaging) in visual cortex (Buchanan et al., 2012) and cerebellum (Rossi et al., 2012), we

428 provide direct evidence that preNMDAR activation either by repetitive activation of mfs or $2 \mathrm{PU}$

429 of glutamate increases presynaptic $\mathrm{Ca}^{2+}$ (Figures 5 and 6). Although the $\mathrm{Ca}^{2+}$ targets remain

430 unidentified, these may include proteins of the release machinery, calcium-dependent protein

431 kinases and phosphatases, and $\mathrm{Ca}^{2+}$ release from internal stores (Banerjee et al., 2016). In

432 addition to facilitating evoked neurotransmitter release, preNMDARs can promote spontaneous

433 neurotransmitter release as indicated by changes in miniature, action potential-independent

434 activity (e.g. mEPSCs) (for recent reviews, see Banerjee et al., 2016; Kunz et al., 2013; Wong et

435 al., 2020). A potential role for preNMDARs in spontaneous, action potential-independent release

436 at mf synapses cannot be discarded.

437

438 Our results show that activation of preNMDARs by physiologically relevant patterns of 439 presynaptic activity enhanced $\mathrm{mf}$ transmission and DG-CA3 information transfer (Figure 4). A 440 previous study reported NMDAR genetic deletion in GCs resulted in memory deficits (e.g. 
441 pattern separation) (McHugh et al., 2007). Although the mechanism is unclear, it could involve

442 activity-dependent preNMDAR regulation of $\mathrm{mf}$ excitatory connections. We also found that

443 preNMDARs facilitate neurotransmitter release in a target cell-specific manner. Like in

444 neocortex (Larsen \& Sjostrom, 2015), such specificity strongly suggests that preNMDARs have

445 distinct roles in controlling information flow in cortical microcircuits. Thus, preNMDAR facilitation

446 of mf synapses onto glutamatergic neurons but not GABAergic interneurons (Figure 8) may fine-

447 tune the CA3 circuit by increasing the excitatory/inhibitory balance.

449 Given the multiple signaling cascades known to regulate NMDARs (Lau \& Zukin, 2007; Sanz-

450 Clemente et al., 2013), preNMDARs at $\mathrm{mf}$ synapses may provide an important site of

451 neuromodulatory control. PreNMDARs have been implicated in the induction of LTP and LTD at

452 excitatory or inhibitory synapses in several brain areas (Banerjee et al., 2016; Wong et al.,

453 2020). While most evidence, at least using robust induction protocols in vitro, indicates that

454 long-term forms of presynaptic plasticity at mf synapses can occur in the absence of NMDAR

455 activation (Castillo, 2012; Nicoll \& Schmitz, 2005), our findings do not discard the possibility that

456 preNMDARs could play a role in vivo during subtle presynaptic activities. As previously reported

457 for corticostriatal LTP (Park et al., 2014), preNMDARs could regulate long-term synaptic

458 plasticity by controlling BDNF release, which is consistent with BDNF-TrkB signaling being

459 implicated in mf-CA3 LTP (Schildt et al., 2013). In addition, BDNF could facilitate glutamate

460 release by enhancing NMDAR function at the presynapse, as previously suggested (W. Chen et

461 al., 2014; Madara \& Levine, 2008), although the precise mechanism(s) remain unclear. By

462 potentiating mf-CA3 transmission, BDNF could also promote epileptic activity (McNamara \&

463 Scharfman, 2012). Lastly, dysregulation of NMDARs is commonly implicated in the

464 pathophysiology of brain disorders such as schizophrenia, autism, and epilepsy (Lau \& Zukin,

465 2007; Paoletti et al., 2013). PreNMDAR expression and function have been suggested to be

466 altered in experimental models of disease, including neuropathic pain (Y. Chen et al., 2019; 
Zeng et al., 2006), and epilepsy (Yang et al., 2006). At present, however, in vivo evidence for the involvement of preNMDARs in brain function and disease is rather indirect (Bouvier et al., 2015; Wong et al., 2020). The development of specific preNMDAR tools is required to determine

470 the functional impact of these receptors in vivo.

\section{$473 \quad$ Methods}

\section{$476 \quad$ Antibodies}

477 A monoclonal antibody against GluN1 (clone 54.1 MAB363) was obtained from Millipore 478 (Germany) and its specificity was characterized previously (Siegel et al., 1994). An affinity479 purified polyclonal rabbit anti-GluA1-4 (pan-AMPA), corresponding to aa 724-781 of rat, was 480 used and characterised previously (Nusser et al., 1998).

\section{Immunohistochemistry for electron microscopy}

483 Immunohistochemical reactions at the electron microscopic level were carried out using the 484 post-embedding immunogold method as described earlier (Lujan et al., 1996). Briefly, animals 485 ( $n=3$ rats were anesthetized by intraperitoneal injection of ketamine-xylazine $1: 1(0.1 \mathrm{~mL} / \mathrm{kg}$ 486 b.w.) and transcardially perfused with ice-cold fixative containing $4 \%$ paraformaldehyde, $0.1 \%$ 487 glutaraldehyde and $15 \%$ saturated picric acid solution in $0.1 \mathrm{M}$ phosphate buffer (PB) for 15 $488 \mathrm{~min}$. Vibratome sections $500 \mu \mathrm{m}$ thick were placed into $1 \mathrm{M}$ sucrose solution in $0.1 \mathrm{M}$ PB for $2 \mathrm{~h}$ 489 before they were slammed on a Leica EM CPC apparatus. Samples were dehydrated in 490 methanol at $-80^{\circ} \mathrm{C}$ and embedded by freeze-substitution (Leica EM AFS2) in Lowicryl HM 20 491 (Electron Microscopy Science, Hatfield, USA), followed by polymerization with UV light. Then, 492 ultrathin 80-nm-thick sections from Lowicryl-embedded blocks of the hippocampus were picked 
up on coated nickel grids and incubated on drops of a blocking solution consisting of $2 \%$ human serum albumin in $0.05 \mathrm{M}$ TBS and $0.03 \%$ Triton X-100. The grids were incubated with GluN1 or pan-AMPA antibodies $(10 \mu \mathrm{g} / \mathrm{mL}$ in $0.05 \mathrm{M}$ TBS and $0.03 \%$ Triton $\mathrm{X}-100$ with $2 \%$ human serum albumin) at $28{ }^{\circ} \mathrm{C}$ overnight. The grids were incubated on drops of goat anti-rabbit $\lg \mathrm{G}$ conjugated to $10 \mathrm{~nm}$ colloidal gold particles (Nanoprobes Inc.) in $2 \%$ human serum albumin and $0.5 \%$ polyethylene glycol in $0.05 \mathrm{M}$ TBS and $0.03 \%$ Triton $\mathrm{X}-100$. The grids were then washed in

499 TBS and counterstained for electron microscopy with 1\% aqueous uranyl acetate followed by 500 Reynolds's lead citrate. Ultrastructural analyses were performed in a JEOL-1010 electron 501 microscope.

\section{Hippocampal slice preparation}

504 Animal handling followed an approved protocol by the Albert Einstein College of Medicine Institutional Animal Care and Use Committee in accordance with the National Institute of Health guidelines. Acute rat hippocampal slices (400 $\mu \mathrm{m}$ thick) were obtained from Sprague-Dawley

507 rats, from postnatal day 17 (P17) to P28 of either sex. For procedures regarding transgenic mouse slice preparation, see below. The hippocampi were isolated and cut using a VT1200s microslicer (Leica Microsystems Co.) in a solution containing (in mM): 215 sucrose, $2.5 \mathrm{KCl}, 26$ $\mathrm{NaHCO}_{3}, 1.6 \mathrm{NaH}_{2} \mathrm{PO}_{4}, 1 \mathrm{CaCl}_{2}, 4 \mathrm{MgCl}_{2}, 4 \mathrm{MgSO}_{4}$ and 20 glucose. Acute slices were placed

511 in a chamber containing a 1:1 mix of sucrose cutting solution and normal extracellular artificial 512 cerebrospinal fluid (ACSF) recording solution containing (in mM): $124 \mathrm{NaCl}, 2.5 \mathrm{KCl}, 26$ $513 \mathrm{NaHCO}_{3}, 1 \mathrm{NaH}_{2} \mathrm{PO}_{4}, 2.5 \mathrm{CaCl}_{2}, 1.3 \mathrm{MgSO}_{4}$ and 10 glucose incubated in a warm-water bath at $51433-34{ }^{\circ} \mathrm{C}$. The chamber was brought to room temperature for at least 15 min post-sectioning 515 and the 1:1 sucrose-ACSF solution was replaced by ACSF. All solutions were equilibrated with $51695 \% \mathrm{O}_{2}$ and $5 \% \mathrm{CO}_{2}(\mathrm{pH} 7.4)$. Slices were allowed to recover for at least $45 \mathrm{~min}$ in the ACSF 517 solution before recording. For physiological $\mathrm{Mg}^{+2}$ and $\mathrm{Ca}^{+2}$ experiments, ACSF solutions were 518 adjusted to (in $\mathrm{mM}$ ): $1.2 \mathrm{MgSO}_{4}$, and $1.2 \mathrm{CaCl}_{2}$ and temperature was maintained at $35 \pm 0.1{ }^{\circ} \mathrm{C}$ 
519 in the submersion-type recording chamber heated by a temperature controller (TC-344B Dual

520 Automatic Temperature Controller, Warner Instruments).

521

\section{Electrophysiology}

523 Electrophysiological recordings were performed at $26.0 \pm 0.1^{\circ} \mathrm{C}$ (unless otherwise stated) in a

524 submersion-type recording chamber perfused at $2 \mathrm{~mL} / \mathrm{min}$ with normal ACSF supplemented 525 with the $\mathrm{GABA}_{\mathrm{A}}$ receptor antagonist picrotoxin $(100 \mu \mathrm{M})$ and the selective AMPA receptor 526 (AMPAR) antagonist LY303070 at a low concentration $(0.5 \mu \mathrm{M})$ to minimize CA3-CA3 recurrent 527 activity, or at a high concentration $(15 \mu \mathrm{M})$ to isolate KAR-EPSCs and KAR-EPSPs to assess 528 monosynaptic mf transmission. Whole-cell recordings were made from CA3 pyramidal cells 529 voltage clamped at $-70 \mathrm{mV}$ using patch-type pipette electrodes (3-4 $\mathrm{m} \Omega$ ) containing (in $\mathrm{mM}$ ):

530131 cesium gluconate, $8 \mathrm{NaCl}, 1 \mathrm{CaCl}_{2}, 10 \mathrm{EGTA}, 10$ glucose, 10 HEPES, and $2 \mathrm{MK}-801 \mathrm{pH}$ 5317.25 (280-285 mOsm) unless specified otherwise. $\mathrm{KOH}$ was used to adjust $\mathrm{pH}$. Series 532 resistance (8-15 $\mathrm{M} \Omega$ ) was monitored throughout all experiments with a $-5 \mathrm{mV}, 80 \mathrm{~ms}$ voltage 533 step, and cells that exhibited a series resistance change (>20\%) were excluded from analysis.

534 A stimulating bipolar electrode (theta glass, Warner Instruments) was filled with ACSF and 535 placed in stratum lucidum to selectively activate mfs using a DS2A Isolated Voltage Stimulator 536 (Digitimer Ltd.) with a $100 \mu$ s pulse width duration. AMPAR-EPSCs were recorded for a 537 baseline period of two minutes and low-frequency facilitation (LFF) was induced by stepping the 538 stimulation frequency from 0.1 to $1 \mathrm{~Hz}$ for two minutes. Facilitation was measured by taking a 539 ratio of the mean EPSC during the steady-state, LFF period of activity and the two-minute 540 baseline $\left(\right.$ EPSC $_{1 \mathrm{~Hz}} / \mathrm{EPSC}_{0.1 \mathrm{~Hz}}$ ) before and after bath-application of NMDAR antagonists.

542 To qualify for analysis, mf responses met three criteria: 1) The $20-80 \%$ rise time of the AMPAR-

543 EPSC was less than $1 \mathrm{~ms}, 2$ ) LFF was greater than $150 \%, 3$ ) The AMPAR-EPSC displayed at 544 least $70 \%$ sensitivity to the group $2 / 3$ mGluR agonist, DCG-IV $(1 \mu \mathrm{M})$. Isolated KAR-EPSCs 
545 were elicited by 2 pulses with a 5 ms inter-stimulus-interval for LFF experiments. Baseline

546 measurements were acquired at least 10 min after "break-in" to achieve optimal intracellular

547 blockade of postsynaptic NMDARs by MK-801 (2 mM) in the patch-pipette. To transect mf

548 axons in acute slices, a $45^{\circ}$ ophthalmic knife (Alcon Surgical) was used to make a diagonal cut

549 across the hilus from the dorsal to ventral blades of the DG, and the subregion CA3b was

550 targeted for patch-clamp recordings. For D-APV (2 mM) puff experiments, a puffer device

551 (Toohey Company) was set to deliver 2-3 puffs of $100 \mathrm{~ms}$ duration at 3-4 psi during the two

552 minutes of LFF activity. The puffer pipette was placed at least $200 \mu \mathrm{m}$ away from the recording

553 site and both the puff pipette and hippocampal slice were positioned to follow the direction of the

554 laminar perfusion flow in a low profile, submersion-type chamber (RC-26GLP, Warner

555 Instruments). Burst-induced facilitation was elicited by 5 pulses at $25 \mathrm{~Hz}$ with a $0.03 \mathrm{~Hz}$ inter-

556 trial-interval for a baseline period of $10 \mathrm{~min}$. Facilitation was measured by calculating the ratio of

557 the mean KAR-EPSC peak of the $5^{\text {th }}$ pulse to the $1^{\text {st }}$ pulse $\left(P_{5} / P_{1}\right)$ before and after bath-

558 application of MK-801 (50 $\mu \mathrm{M})$. To study KAR induced action potentials, CA3 pyramidal cells

559 were whole-cell patch-clamped with internal solution containing in $(\mathrm{mM}): 112$ potassium

560 gluconate, $17 \mathrm{KCl}, 0.04 \mathrm{CaCl}_{2}, 0.1 \mathrm{EGTA}, 10 \mathrm{HEPES}, 10 \mathrm{NaCl}, 2 \mathrm{MgATP}, 0.2 \mathrm{Na}_{3} \mathrm{GTP}$ and 2

561 MK-801, pH 7.2 (280-285 mOsm). Current-clamped CA3 cells were held at $-70 \mathrm{mV}$ during burst

562 stimulation of $\mathrm{mfs}(5$ pulses at $25 \mathrm{~Hz}$ ) to monitor evoked action potentials. Spike-transfer was

563 measured by quantifying mean number of spikes/burst for a $10 \mathrm{~min}$ period before and after bath

564 application of MK-801 $(50 \mu \mathrm{M})$. Robust sensitivity to the AMPAR/KAR selective antagonist

565 NBQX $(10 \mu \mathrm{M})$ confirmed KAR-EPSC responses. Similarly, CA3 pyramidal cells were kept in

566 current-clamp mode for AMPAR-mediated action potential monitoring in the presence of

567 LY303070 $(0.5 \mu \mathrm{M})$ and picrotoxin $(100 \mu \mathrm{M})$. AMPAR-mediated $\mathrm{mf}$ action potentials were

568 confirmed by blockade of responses following application of DCG-IV $(1 \mu \mathrm{M})$. Both hilar mossy

569 cells and CA3 interneurons were visually patched-loaded with Alexa 594 (35 $\mu \mathrm{M})$ and

570 morphological identity was confirmed by two-photon laser scanning imaging at the end of 
571 experiments. Hilar mossy cells were voltage clamped at $-70 \mathrm{mV}$ and a bipolar electrode was

572 placed in the DG to activate $\mathrm{mf}$ inputs. The data analysis and inclusion criteria used for $\mathrm{mf}$

573 experiments (described above) was also implemented for hilar mossy cell recordings. CA3

574 interneurons were voltage clamped at $-70 \mathrm{mV}$ and burst-stimulated, facilitation was assessed as

575 previously mentioned. Both facilitating and depressing $\mathrm{mf}$ responses were included for analysis

576 given the diversity of mf-CA3 interneuron transmission (Toth et al., 2000). Whole-cell voltage

577 and current clamp recordings were performed using an Axon MultiClamp 700B amplifier

578 (Molecular Devices). Signals were filtered at $2 \mathrm{kHz}$ and digitized at $5 \mathrm{kHz}$. Stimulation and

579 acquisition were controlled with custom software (Igor Pro 7).

\section{Transgenic animals}

582 Grin1-floxed littermate mice of either sex (P16-20) were injected with $1 \mu \mathrm{L}$ of AAV5-CamKIIeGFP, AAV5-CamKII-CreGFP, AAV5-CamKII-mCherry, or AAV5-CamKII-mCherry-Cre viruses at a rate of $0.12 \mu \mathrm{L} / \mathrm{min}$ at coordinates $(-1.9 \mathrm{~mm} \mathrm{~A} / \mathrm{P}, 1.1 \mathrm{~mm} \mathrm{M} / \mathrm{L}, 2.4 \mathrm{~mm} \mathrm{D} / \mathrm{V})$ targeting the DG using a stereotaxic apparatus (Kopf Instruments). Two weeks post-surgery mice were sacrificed for electrophysiology or $\mathrm{Ca}^{2+}$ imaging experiments. Mice were transcardially perfused

587 with $20 \mathrm{~mL}$ of cold NMDG solution containing in (mM): $93 \mathrm{NMDG}, 2.5 \mathrm{KCl}, 1.25 \mathrm{NaH}_{2} \mathrm{PO}_{4}, 30$ $588 \mathrm{NaHCO}_{3}, 20$ HEPES, 25 glucose, 5 sodium ascorbate, 2 Thiourea, 3 sodium pyruvate, 10 $589 \mathrm{MgCl}_{2}, 0.5 \mathrm{CaCl}_{2}$, brought to $\mathrm{pH} 7.35$ with $\mathrm{HCl}$. The hippocampi were isolated and cut using a 590 VT1200s microslicer in cold NMDG solution. Acute mouse slices were placed in an incubation

591 chamber containing normal ACSF solution that was kept in a warm water bath at $33-34{ }^{\circ} \mathrm{C}$. All 592 solutions were equilibrated with $95 \% \quad \mathrm{O}_{2}$ and $5 \% \quad \mathrm{CO}_{2}(\mathrm{pH} 7.4)$. Post-sectioning, slices 593 recovered at room temperature for at least $45 \mathrm{~min}$ prior to experiments. For NMDAR/AMPAR 594 ratios, GCs were patch-clamped with the cesium internal solution previously mentioned 595 containing either Alexa $594(35 \mu \mathrm{M})$ for GFP ${ }^{+}$cells (laser tuned to $830 \mathrm{~nm} / 910 \mathrm{~nm}$, respectively) 596 or Alexa $488(35 \mu \mathrm{M})$ for $\mathrm{mCherry}^{+}$cells (laser tuned to $910 \mathrm{~nm} / 780 \mathrm{~nm}$, respectively). AMPAR- 
597 EPSCs were recorded at $-65 \mathrm{mV}$ in the presence of picrotoxin $(100 \mu \mathrm{M})$ by placing a bipolar 598 electrode near the medial perforant path and delivering a $100 \mu$ s pulse width duration using an 599 Isoflex stimulating unit. AMPAR-EPSCs were acquired for at least 5 min followed by bath600 application of NBQX $(10 \mu \mathrm{M})$ to isolate NMDAR-EPSCs. GCs were brought to $+40 \mathrm{mV}$ to 601 alleviate magnesium block and record optimal NMDAR-EPSCs. NMDAR/AMPAR ratios were 602 measured by taking the mean NMDAR-EPSC/AMPAR-EPSC for a 5 min period of each 603 component. Only acute mouse slices with optimal GFP and mCherry reporter fluorescence (i.e. 604 robust expression, $\geq 75 \%$ of dentate gyrus fluorescence) were used for electrophysiology, and $605 \mathrm{Ca}^{2+}$ and BDNF imaging experiments. Grin1-floxed animals (The Jackson Laboratory) were 606 kindly provided by Dr. Michael Higley (Yale University).

\section{Optogenetics}

609 Grin 1 floxed and control mice of either sexes (P17-20) were injected with a 1:2 mix of AAV5CamKII-CreGFP/AAV-DJ-FLEX-ChIEF-tdTomato viruses targeting the DG, using the same coordinates described above. At least four weeks post-surgery acute hippocampal slices were

612 prepared as previously described and slices showing optimal GFP and tdTomato expression 613 were used for electrophysiology experiments. Mf optical burst-stimulation was elicited by using a 614 Coherent $473 \mathrm{~nm}$ laser $(4-8 \mathrm{~mW})$ delivering 5 pulses at $25 \mathrm{~Hz}$ with a 1-2 ms pulse width 615 duration. Facilitation was measured by taking a ratio of the mean AMPAR-EPSC peak of the $5^{\text {th }}$ 616 pulse to the $1^{\text {st }}$ pulse $\left(P_{5} / P_{1}\right)$ in control and Grin1-cKO animals.

\section{Two-photon calcium imaging and MNI-glutamate uncaging}

619 mCherry+ GCs were patch-loaded with an internal solution containing in (mM): $130 \mathrm{KMeSO}_{4}, 10$ 620 HEPES, $4 \mathrm{MgCl}_{2}, 4 \mathrm{Na}_{2} \mathrm{ATP}, 0.4 \mathrm{NaGTP}, 10$ sodium phosphocreatine, 0.035 Alexa 594 (red 621 morphological dye), and 0.2 Fluo-5F (green calcium indicator), 280-285 mOsm. KOH was used 622 to adjust pH. GCs near the hilar border were avoided and GCs that exhibited adult-born GCs 
623 electrophysiological properties were excluded from analysis. GCs were kept in voltage clamp

624 configuration at $-50 \mathrm{mV}$ for at least $1 \mathrm{hr}$ to allow the diffusion of dyes to $\mathrm{mf}$ boutons. Recordings

625 were obtained in ACSF solution containing in $(\mathrm{mM}): 124 \mathrm{NaCl}, 2.5 \mathrm{KCl}, 26 \mathrm{NaHCO}_{3}, 1$

$626 \mathrm{NaH}_{2} \mathrm{PO}_{4}, 4 \mathrm{CaCl}_{2}, 0 \mathrm{MgSO}_{4}, 10$ glucose, $0.01 \mathrm{NBQX}, 0.1$ picrotoxin, and $0.01 \mathrm{D}$-serine. Using

627 an Ultima 2P laser scanning microscope (Bruker Corp) equipped with an Insight Deep See laser

628 (Spectra Physics) tuned to $830 \mathrm{~nm}$, the "red" photomultiplier tube (PMT) was turned on and with

629 minimal pockel power the red signal was used to identify the mf axon. With $512 \times 512$ pixel

630 resolution $\mathrm{mf}$ axons were followed for at least $200 \mu \mathrm{m}$ from the DG towards CA3, until bouton

631 structures were morphologically identified and measured ( $>3 \mu \mathrm{m}$ in diameter). GCs were

632 switched to current clamp mode held at $-70 \mathrm{mV}$ and $1 \mathrm{~ms}$ current injections were used to elicit a

633 burst of 5 action potentials at $25 \mathrm{~Hz}$. Using line scan analysis software (PrairieView 5.4, Bruker

634 Corp.), a line was drawn across the diameter of the bouton at a magnification of at least 16X.

635 The "green" PMT channel was turned on and 1,000 line scans were acquired in a 2 s period.

636 Action potential induction was delayed for $400 \mathrm{~ms}$ to collect a baseline fluorescence time period.

637 Calcium transients (CaTs) were acquired with a 1 min inter-trial-interval and analyzed using the

$638 \Delta \mathrm{G} / \mathrm{R}$ calculation: $\left(\mathrm{G}-\mathrm{G}_{0}\right) / \mathrm{R}$. CaTs from control animals were compared to Grin1-cKO by taking

639 the mean peak $\Delta \mathrm{G} / \mathrm{R}$ value for a $30 \mathrm{~ms}$ period of the $5^{\text {th }}$ action potential. In similar fashion, CaT

640 signals in acute rat hippocampal slices were acquired and tested for sensitivity to D-APV (100

$641 \mu \mathrm{M}$ ) while adjusting $\mathrm{ACSF} \mathrm{MgSO}_{4}$ concentration to $1.3 \mathrm{mM}$ and $\mathrm{CaCl}_{2}$ to $2.5 \mathrm{mM}$ in the absence

642 of NBQX.

644 For glutamate uncaging experiments, GCs that were mCherry+ were patch-loaded using the 645 internal solution previously described, and a small volume (12 $\mathrm{mL})$ of recirculated ACSF solution 646 containing in (mM): $124 \mathrm{NaCl}, 2.5 \mathrm{KCl}, 26 \mathrm{NaHCO}_{3}, 1 \mathrm{NaH}_{2} \mathrm{PO}_{4}, 4 \mathrm{CaCl}_{2}, 0 \mathrm{MgSO}_{4}, 10$ 647 glucose, 2.5 MNI-glutamate, 0.01 NBQX, 0.1 picrotoxin, and 0.01 D-serine. A MaiTai HP laser 648 (Spectra Physics) was tuned to $720 \mathrm{~nm}$ to optimally uncage glutamate and elicit CaTs in GC 
dendritic spines. Following the measurement of CaTs in GC spines, mf boutons were identified and to mimic bursting activity, 5 uncaging pulses (1 ms duration) were delivered at $25 \mathrm{~Hz}$. The

651 acquired CaTs in spines and boutons were analyzed using the $\Delta \mathrm{G} / \mathrm{R}$ calculation in control and

652 Grin1-cKO animals. In a subset of control boutons, D-APV (100 $\mu \mathrm{M})$ was applied to detect CaT 653 sensitivity to NMDAR antagonism.

655 Two-photon BDNF-phluorin imaging

656 Grin1 floxed and control mice of both sexes (P16-20) were injected with a 1:2 mix of AAV5-

657 CamKII-mCherryCre/AAV-DJ-DIO-BDNF-phluorin viruses targeting the DG using the same

658 coordinates as above. At least four weeks post-surgery acute hippocampal slices were 659 prepared as previously described and slices showing optimal GFP and mCherry expression 660 were taken for imaging sessions. For stimulation, a monopolar micropipette electrode was 661 placed in the stratum lucidum at least $250 \mu \mathrm{m}$ away from the imaging site. The Insight Deep 662 See laser (Spectra Physics) was tuned to $880 \mathrm{~nm}$ and the imaging site was selected by the 663 appearance of fibers and bouton structures in the stratum lucidum. Using $512 \times 512$ pixel 664 resolution identified boutons measuring at least $3 \mu \mathrm{m}$ in diameter were selected as a region of 665 interest (ROI) magnified to 4-6X and a baseline acquisition of 100 consecutive images at $1 \mathrm{~Hz}$ 666 using T-series software (PrairieView 5.4, Bruker Corp.) was acquired (Park et al., 2014). 667 Following the baseline acquisition a repetitive stimulation consisting of 125 pulses at $25 \mathrm{~Hz}$ was 668 delivered $2 x$, triggering an acquisition of 200 consecutive images at $1 \mathrm{~Hz}$. The fluorescence 669 intensity of the bouton $\mathrm{ROI}$ was measured using ImageJ software to calculate $\Delta \mathrm{F} / \mathrm{F}$ of the 670 BDNF-pHluorin signal. To verify reactivity of the ROI an isosmotic solution of $\mathrm{NH}_{4} \mathrm{Cl}(50 \mathrm{mM})$ 671 was added at the end of the imaging session as previously reported (Park et al., 2014). The 672 same experimental and analysis procedure was implemented to measure BDNF release 673 triggered by $\mathrm{mf}$ burst stimulation consisting of 5 pulses at $100 \mathrm{~Hz}, 50 \mathrm{x}$, every $0.5 \mathrm{~s}$. 


\section{Viruses}

676 AAV5-CamKII-eGFP and AAV5-CamKII-CreGFP viruses were acquired from UPenn Vector 677 Core. AAV5-CamKII-mCherry and AAV5-CamKII-mCherry-Cre were obtained from UNC Chapel 678 Hill Vector Core. The AAV-DJ-FLEX-ChIEF-tdTomato and AAV-DJ-DIO-BDNF-phluorin viruses 679 were custom ordered and obtained from UNC Chapel Hill Vector Core. The DNA of the ChIEF 680 virus was a generous gift from Dr. Pascal Kaeser (Harvard University), and the DNA of the 681 BDNF-pHluorin was kindly provided by Dr. Hyungju Park (Korea Brain Research Institute).

\section{Chemicals \& Drugs}

684 Picrotoxin and all chemicals used to prepare cutting, recording, and internal solutions were acquired from MilliporeSigma. All NMDAR antagonists (D-APV, MK-801, R-CPP), NMDAR agonist (D-serine), the group 2/3 mGluR agonist (DCG-IV) and MNI-glutamate for uncaging experiments were purchased from Tocris Bioscience. D-APV was also acquired from the NIMH

688 Chemical Synthesis Drug Program. NBQX was purchased from Cayman Chemical Company.

689 The noncompetitive AMPAR selective antagonist LY303070 was custom ordered from ABX 690 Chemical Company. Alexa 594 morphological dye, Alexa 488, and the $\mathrm{Ca}^{2+}$ indicator Fluo-5F 691 (Invitrogen) were purchased from ThermoFisher Scientific.

692

\section{Statistical analysis and Data Acquisition}

694 All data points from experiments were tested for normality using a Shapiro-Wilk test ( $p$ value $<$ $6955 \%$ for a normal distribution). Statistical significance was determined if $p$ value $<0.05$. 696 Experiments with a normal distribution and an $\mathrm{N}>$ to 7 cells were tested for statistical 697 significance with a paired Student $t$-test. Experiments with $\mathrm{N}<7$ cells or skewed distributions 698 were tested for statistical significance using a paired Wilcoxon signed rank sum test. For 699 experiments comparing control and Grin1-cKO animals, statistical significance was determined 700 using Unpaired $t$-test and Mann-Whitney test $(U<0.05)$. All statistical tests were performed 
bioRxiv preprint doi: https://doi.org/10.1101/2021.01.21.427714; this version posted May 11, 2021. The copyright holder for this preprint (which

was not certified by peer review) is the author/funder, who has granted bioRxiv a license to display the preprint in perpetuity. It is made available under aCC-BY 4.0 International license.

701 using Origin Pro 9 (Origin Lab). Experimenters were blind to the identity of the virus injected in

702 transgenic Grin1 floxed mice during the acquisition of data in CA3 electrophysiology and two-

703 photon imaging. However, data analysis could not be performed blind in those experiments in

704 which NMDAR/AMPAR ratios in GCs were examined in order to assess the efficiency of the

705 cKO.

706 


\section{Figure Legends}

Figure 1. Anatomical and functional evidence for preNMDARs at mossy fiber synapses.

(A) Image of a mossy fiber (mf) giant bouton and postsynaptic spines (s). (B, C) Higher

711 magnification of mf synapses. Arrows indicate postsynaptic GluN1 whereas arrowheads indicate

712 presynaptic GluN1. Calibration bars: $500 \mathrm{~nm}$. (D) Mossy fiber (mf) and associational

713 commissural (ac) synaptic GluN1 immuno-particle radial distribution (30 nm bins), mf: 34

714 synapses, 100 presynaptic particles; ac: 25 synapses, 24 presynaptic particles; 3 animals. (E)

715 AMPAR-ESPCs were recorded at $V_{h}=-70 \mathrm{mV}$ in the presence of $0.5 \mu \mathrm{M}$ LY303070 and $100 \mu \mathrm{M}$

716 picrotoxin. Low-frequency facilitation (LFF), induced by stepping stimulation frequency from 0.1

717 to $1 \mathrm{~Hz}$, was assessed before and after bath application of MK-801 (50 $\mu \mathrm{M})$. MK-801

718 significantly reduced LFF (baseline $378 \pm 57 \%$, MK-801 $270 \pm 48 \%, \mathrm{n}=10$ cells, 9 animals;

719 baseline vs MK-801, $p=3.8 \times 10^{-5}$, paired $t$-test). In all panels of this figure: representative

720 traces (top), representative experiment (middle), normalized LFF and summary plot (bottom).

721 DCG-IV $(1 \mu \mathrm{M})$ was applied at the end of all recordings to confirm mf-CA3 transmission. (F) D-

722 APV $(100 \mu \mathrm{M})$ or R-CPP $(50 \mu \mathrm{M})$ application also reduced LFF (baseline $546 \pm 50 \%$, D-APV/R-

723 CPP $380 \pm 38 \%, \mathrm{n}=7$ cells, 5 animals; baseline vs D-APV/R-CPP, $\mathrm{p}=0.00743$, paired $t$-test).

724 (G) KAR-EPSCs were recorded at $\mathrm{V}_{\mathrm{h}}=-70 \mathrm{mV}$ in the presence of $15 \mu \mathrm{M}$ LY303070 and $100 \mu \mathrm{M}$

725 picrotoxin. In addition, NMDAR-mediated transmission was blocked intracellularly by loading

726 MK-801 (2 mM) in the patch-pipette. Bath application of MK-801 (50 $\mu \mathrm{M})$ significantly reduced

727 LFF (baseline $278 \pm 40 \%$, MK-801 $195 \pm 26 \% \mathrm{n}=8$ cells, 6 animals; baseline vs MK-801, $\mathrm{p}=$

728 0.00259, paired $t$-test). Data are presented as mean \pm s.e.m. ${ }^{* *} p<0.01 ;{ }^{* * *} p<0.005 ;{ }^{* * *} p<$

7290.001.

730

731 Figure 1-figure supplement 1. Immunogold-EM reveals negligible presynaptic AMPAR particle

732 distribution. (A,B) Images of mossy fiber (mf) and associational commissural (ac) synapses, 
733 postsynaptic spines (s). (C) AMPAR immuno-particle distribution (30 nm bins), mf: 102

734 synapses, 8 presynaptic particles; ac: 75 synapses, 6 presynaptic particles; 3 animals. Dashed

735 line represents synaptic cleft.

736

737 Figure 1-figure supplement 2. (A) Stable low-frequency facilitation (LFF) of AMPAR-EPSCs. In 738 naïve slices (interleaved experiments), LFF remained unchanged throughout the recording 739 session (baseline $335 \pm 62 \%$, naïve $363 \pm 63 \%, n=10$ cells, 9 animals; $p=0.185$, Wilcoxon-

740 Signed Ranks test, baseline vs nal̈ve). DCG-IV $(1 \mu \mathrm{M})$ was applied at the end of all recordings

741 to confirm mf-CA3 transmission. (B) LFF of KAR-EPSCs was also stable in interleaved, naïve

742 slices (baseline $274 \pm 33 \%$, naïve $278 \pm 25 \%, n=9$ cells, 6 animals; $p=0.236$, Wilcoxon

743 Signed Ranks test, baseline vs naïve). NBQX $(10 \mu \mathrm{M})$ was applied at the end of all recordings

744 to confirm mf KAR transmission. Data are presented as mean \pm s.e.m.

Figure 1-figure supplement 3. Intracellular MK-801 effectively blocked postsynaptic NMDARs.

747 Representative NMDAR-EPSCs $\left(\mathrm{V}_{\mathrm{h}}=+40 \mathrm{mV}\right)$ from CA3 pyramidal neurons patch-loaded with

7482 mM MK-801 (left) or naïve internal solution (right). Mf inputs were stimulated with a bipolar

749 electrode (theta-glass pipette) in stratum lucidum delivering in the presence of picrotoxin (100

$750 \mu \mathrm{M})$ and NBQX $(10 \mu \mathrm{M})$. Bath-application of MK-801 $(50 \mu \mathrm{M})$ blocked NMDAR currents in naïve

751 cells to a similar magnitude as cells patch-loaded with MK-801 ( $\mathrm{n}=5$ cells, 4 animals in each

752 condition; $U=0.676$, Mann-Whitney test). Note that CA3 pyramidal neurons were loaded for at

753 least 3-5 minutes before recording started at $+40 \mathrm{mV}$.

754

755 Figure 2. GluN1 deletion from granule cells reduces mf-CA3 facilitation. (A)

756 Representative images showing GCs patch-loaded with Alexa 594 (35 $\mu \mathrm{M})$ (left), and GFP

757 expression in GCs (right). (B) Representative EPSCs recorded from control (GFP ${ }^{+}$) and Grin1-

758 cKO (Cre-GFP ${ }^{+}$) GCs. Synaptic responses were elicited by activating medial perforant-path 
759 inputs. AMPAR-ESPCs were recorded at $\mathrm{V}_{\mathrm{h}}=-65 \mathrm{mV}$ in the presence of $100 \mu \mathrm{M}$ picrotoxin,

760 NMDAR-EPSCs were isolated with $10 \mu \mathrm{M}$ NBQX and recorded at +40 mV. MK-801 (20 $\mu \mathrm{M})$ was

761 applied at the end of each recording. (C) Summary plot demonstrating that GluN1 deletion from

762 GCs virtually abolished NMDAR-mediated transmission indicated by a strong reduction of

763 NMDAR/AMPAR in Grin1-cKO GCs as compared to controls (control $1.61 \pm 0.18, \mathrm{n}=9$ cells, 9

764 animals, Grin1-cKO $0.18 \pm 0.04, \mathrm{n}=10$ cells, 10 animals; control vs Grin1-cKO, $\mathrm{p}=9.2 \times 10^{-6}$,

765 unpaired $t$-test). (D) LFF was significantly reduced in GluN1-deficient animals (control, $430 \pm$

$7665 \%, \mathrm{n}=13$ cells, 10 animals; Grin1-cKO, $291 \pm 6 \%, \mathrm{n}=11$ cells, 10 animals; $\mathrm{p}=0.0239$,

767 unpaired $t$-test). Representative traces (left) and summary plot (right). LFF was induced by

768 stepping stimulation frequency from 0.1 to $1 \mathrm{~Hz}$. DCG-IV $(1 \mu \mathrm{M})$ was added at the end of each

769 experiment. Data are presented as mean \pm s.e.m. ${ }^{*} p<0.05 ;{ }^{* * * *} p<0.001$.

770

771 Figure 3. Reduced facilitation by NMDAR antagonism is independent of the GC

772 somatodendritic compartment. (A) KAR-EPSCs were recorded at $\mathrm{V}_{\mathrm{h}}=-70 \mathrm{mV}$ in the presence

773 of $15 \mu \mathrm{M}$ LY303070 and $100 \mu \mathrm{M}$ picrotoxin. In addition, NMDAR-mediated transmission was

774 blocked intracellularly by loading MK-801 (2 mM) in the patch-pipette. LFF of KAR-EPSCs was

775 assessed as in Fig. 1G but with transected mf axons (see Methods). Bath application of MK-801

$776(50 \mu \mathrm{M})$ significantly reduced LFF (baseline $213 \pm 9 \%$, MK-801 $181 \pm 10 \%, \mathrm{n}=8$ cells, 7

777 animals; baseline vs MK-801, $\mathrm{p}=0.002$, paired $t$-test). In all panels of this figure: recording

778 arrangement (inset), representative traces (top), representative experiment (middle), normalized

779 LFF and summary plot (bottom). (B) Stable LFF in transected, naïve slices (baseline $186 \pm$

$78010 \%$, naïve $196 \pm 5 \%, n=8$ cells, 7 animals; baseline vs naïve, $p=0.278$, paired $t$-test). (C)

781 LFF was induced before and during puff application of D-APV (2 mM) in stratum lucidum. This

782 manipulation significantly reduced facilitation (baseline $220 \pm 19 \%$, D-APV puff $176 \pm 11 \%, n=7$

783 cells, 7 animals; baseline vs D-APV puff, $\mathrm{p}=0.003$, paired $t$-test). (D) Stable LFF in acute slices

784 during puff application of ACSF (baseline $210 \% \pm 12$, naïve $213 \% \pm 9, n=7$ cells, 7 animals; 
baseline vs naïve, $\mathrm{p}=0.778$, paired $t$-test). NBQX $(10 \mu \mathrm{M})$ was applied at the end of all recordings to confirm mf KAR transmission. Data are presented as mean \pm s.e.m. ${ }^{* * *} \mathrm{p}<0.005$.

Figure 3-figure supplement 1. Targeting preNMDARs located in mf axons but not granule cells. (A) Field view of a representative hippocampal slice showing a surgical cut between DG and CA3. (B) Local D-APV puff application (vertical arrow, 2 puffs at $0.1 \mathrm{~Hz}$ ) blocks NMDAR currents recorded at $V_{h}=-50 \mathrm{mV}$ and washes out in less than 10 minutes ( $n=7$ cells, 5 animals,

$792 p=5 \times 10^{-8}$, paired $t$-test). Inset depicts the recording paradigm of the experiment (left), the 793 representative NMDAR currents (top) and the summary time course (bottom) where arrows 794 denote the onset of D-APV (2 mM) puff application. Mfs were stimulated with a bipolar electrode 795 (theta-glass pipette) in stratum lucidum in the presence of $100 \mu \mathrm{M}$ picrotoxin and $10 \mu \mathrm{M}$ NBQX. (C) D-APV puff application in CA3 did not reduce NMDAR transmission in GCs ( $\mathrm{n}=6$ cells, 5 animals, control vs D-APV puff, $U=0.594$, Mann Whitney test). Excitatory inputs were stimulated with a monopolar electrode placed in the medial molecular layer/inner molecular layer, in the presence of $100 \mu \mathrm{M}$ picrotoxin and $10 \mu \mathrm{M}$ NBQX, while GCs were clamped at $\mathrm{V}_{\mathrm{h}}=$ $+40 \mathrm{mV}$. Data are presented as mean \pm s.e.m.

801

Figure 4. PreNMDARs contribute significantly to burst-induced facilitation and spike

transfer. (A) Representative images showing expression of GFP-Cre (left) and ChIEFEPSCs from control (left) and Grin1-cKO (right) CA3 pyramidal neurons recorded at $\mathrm{V}_{\mathrm{h}}=-65 \mathrm{mV}$ and evoked by optical burst-stimulation (5 pulses at $25 \mathrm{~Hz}$ ) of stratum lucidum. Blue arrows

807 indicate light stimulation. (C) Summary plot of burst-induced facilitation measured as P5/P1 808 ratio of optical responses; facilitation was significantly reduced in Grin1-cKO animals as 809 compared to control (Grin1-cKO $187 \pm 16 \%, \mathrm{n}=12$ cells, 9 animals; control $255 \pm 22 \%, \mathrm{n}=9$ 810 cells, 8 animals; Grin1-cKO vs control, $p=0.0167$, unpaired $t$-test). (D) Burst-stimulation 
811 induced KAR-EPSCs were isolated and recorded as described in Fig. 3, bath-application of MK-

$812801(50 \mu \mathrm{M})$ significantly reduced facilitation (baseline $601 \pm 107 \%$, MK-801 $464 \pm 84 \%, \mathrm{n}=13$

813 cells, 10 animals; baseline vs $M K-801, p=0.00042$, paired $t$-test). In panels $D$ and $E$ of this

814 figure: representative traces (left), representative experiment (middle), and summary plot (right).

815 (E) Burst-induced facilitation was stable in interleaved, naïve slices (baseline $369 \pm 45 \%$, naïve

$816367 \pm 48 \%, n=9$ cells, 9 animals; $p=0.863$, paired $t$-test). (F) Bath-application of MK-801 (50

$817 \mu \mathrm{M}$ ) reduced KAR-mediated action potentials induced by burst-stimulation (baseline $0.93 \pm 0.17$,

818 MK-801 $0.46 \pm 0.09, n=6$ cells, 5 animals; $p=0.036$, Wilcoxon Signed Ranks test). In panels $\mathrm{F}$

819 and $\mathrm{G}$ of this figure: representative traces (top), representative experiment and summary plot

820 (bottom). (G) Stable KAR-mediated action potentials in interleaved naïve slices (baseline $0.76 \pm$

8210.07 , naïve $0.88 \pm 0.1, n=6$ cells, 5 animals; $p=0.2084$, Wilcoxon Signed Ranks test). NBQX

$822(10 \mu \mathrm{M})$ was applied at the end of all experiments in panels D-G. Data are presented as mean

$823 \pm$ s.e.m. ${ }^{*} p<0.05 ;{ }^{* * *} p<0.001$.

824

825 Figure 4-figure supplement 1 . PreNMDARs contribute to burst-induced facilitation in more 826 physiological conditions: $1.2 \mathrm{mM} \mathrm{Mg}^{+2}, 1.2 \mathrm{mM} \mathrm{Ca}^{+2}$ and $35^{\circ} \mathrm{C}$. KAR-EPSCs were recorded 827 from CA3 pyramidal cells loaded with $2 \mathrm{mM}$ MK-801 in the presence of $15 \mu \mathrm{M}$ LY303070 and $828100 \mu \mathrm{M}$ picrotoxin. (A) Bath-application of MK-801 (50 $\mu \mathrm{M})$ significantly reduced burst-induced 829 facilitation elicited by 5 pulses, $25 \mathrm{~Hz}$ (baseline $450 \pm 67 \%$, MK-801 $366 \pm 63 \%, \mathrm{n}=6$ cells, 4 830 animals; baseline vs MK-801, $p=0.036$, Wilcoxon Signed Ranks test). In panels A and B of this 831 figure: representative traces (left), representative experiment (middle), and summary plot (right).

832 (B) Burst-induced facilitation was stable in interleaved, naïve slices (baseline $462 \pm 63 \%$, naïve $833481 \pm 71 \%, n=5$ cells, 4 animals; $p=0.281$, Wilcoxon Signed Ranks test). Data are presented 834 as mean \pm s.e.m. ${ }^{*} p<0.05$.

836 Figure 4-figure supplement 2. PreNMDARs contribute to action potential firing elicited by 
AMPAR-mediated transmission. (A) Bath-application of MK-801 (50 $\mu \mathrm{M})$ reduced action potentials induced by 5 pulses at $25 \mathrm{~Hz}$ burst-stimulation (baseline $2.47 \pm 0.27$, MK-801 $1.9 \pm$ $0.24, n=6$ cells, 5 animals; $p=0.036$, Wilcoxon Signed Ranks test). In panels $A$ and $B$ of this

841 Stable action potential firing in interleaved naïve slices (baseline $1.55 \pm 0.24$, naïve $1.61 \pm 0.23$,

$842 \mathrm{n}=6$ cells, 5 animals; $p=0.402$, Wilcoxon Signed Ranks test). DCG-IV $(1 \mu \mathrm{M})$ was applied at

843 the end of all experiments in panels A-B. Data are presented as mean \pm s.e.m. ${ }^{*} p<0.05$.

845 Figure 4-figure supplement 3. Intracellular MK-801 effectively blocked postsynaptic NMDARs 846 elicited by burst stimulation ( 5 pulses at $25 \mathrm{~Hz})$. Representative NMDAR-EPSCs $\left(\mathrm{V}_{\mathrm{h}}=+40 \mathrm{mV}\right)$ 847 from CA3 pyramidal neurons patch-loaded with 2 mM MK-801 (left) or naïve internal solution (right). Mf inputs were stimulated with a bipolar electrode (theta-glass pipette) in stratum lucidum delivering in the presence of picrotoxin $(100 \mu \mathrm{M})$ and NBQX $(10 \mu \mathrm{M})$. NMDAR currents were recorded at $\mathrm{V}_{\mathrm{h}}=+40 \mathrm{mV}$ (gray shaded area) followed by a voltage jump to $-70 \mathrm{mV}$ in iMKNMDAR currents of the $5^{\text {th }}$ pulse to a similar magnitude as iMK-801 ( $\mathrm{n}=5$ cells, 4 animals per condition; $U=0.21$, Mann-Whitney test). Data are presented as mean \pm s.e.m.

Figure 5. preNMDARs contribute to presynaptic $\mathrm{Ca}^{2+}$ rise. (A) Representative images showing GCs patch-loaded with Alexa $488(35 \mu \mathrm{M})$ to confirm expression of mCherry (bottom).

857 Representative AMPAR-EPSCs recorded from control (top) or Grin1-cKO (middle) GCs. 858 Synaptic responses were elicited by activating medial perforant-path inputs. AMPAR-ESPCs 859 were recorded at $V_{h}=-65 \mathrm{mV}$ in the presence of $100 \mu \mathrm{M}$ picrotoxin, NMDAR-EPSCs were 860 isolated with $10 \mu \mathrm{M} \mathrm{NBQX}$ and recorded at $+40 \mathrm{mV}$. MK-801 $(20 \mu \mathrm{M})$ was applied at the end of

861 each experiment. Summary plot (bottom) demonstrating that GluN1 deletion from GCs virtually 862 abolished NMDAR-mediated transmission indicated by a strong reduction of NMDAR/AMPAR in 
Grin1-cKO granule cells as compared to controls (control $0.90 \pm 0.17, \mathrm{n}=7$ cells, 6 animals; Grin1-cKO $0.13 \pm 0.05, \mathrm{n}=6$ cells, 6 animals; control vs Grin1-cKO, $\mathrm{p}=3.81 \times 10^{-7}$, unpaired $t$ test). (B) Representative control and Grin1-cKO GCs patch-loaded with Fluo-5F $(200 \mu \mathrm{M})$ and Alexa $594(35 \mu \mathrm{M})$. Arrows indicate the identification of a mf giant bouton, magnified images in

867 white box. (C) Three representative $\mathrm{mf}$ boutons (top) and line scan analysis of calcium 868 transients (CaTs) elicited by 5 action potentials at $25 \mathrm{~Hz}$ (middle, Fluo-5F) and morphological 869 dye (bottom, Alexa 594), in Control and Grin1-cKO animals. Dotted line (yellow) indicates line 870 scan location. Red Channel, Alexa 594; Green Channel, Fluo-5F. (D, E) Peak analysis of the $5^{\text {th }}$ 871 pulse $\Delta G / R$ revealed a significant reduction in $\mathrm{Ca}^{2+}$ rise of Grin1-cKO animals as compared to

872 Control (control $0.046 \pm 0.01, \mathrm{n}=10$ boutons, 8 animals; Grin1-cKO $0.025 \pm 0.004, \mathrm{n}=10$

873 boutons, 8 animals; control vs. Grin1-cKO, $\mathrm{U}=0.017$, Mann-Whitney test). Arrows indicate $\mathrm{mf}$

874 activation. Data are presented as mean \pm s.e.m. ${ }^{*} U<0.05 ;{ }^{* * *} p<0.001$.

875

Figure 5-figure supplement 1 . NMDAR antagonism reveals a reduction in presynaptic $\mathrm{Ca}^{+2}$

877 rise in the presence of $1.3 \mathrm{mM} \mathrm{Mg}^{+2}$ and $2.5 \mathrm{mM} \mathrm{Ca}^{+2}$. (A, B) Granule cells were patch-loaded 878 with Fluo-5F $(200 \mu \mathrm{M})$ and Alexa $594(35 \mu \mathrm{M})$. Line scan analysis of $\mathrm{mf}$ giant bouton calcium 879 transients (CaTs) in response to action potential (AP) stimulation (5 APs, $25 \mathrm{~Hz})$. (C) Line scan 880 signals following D-APV application or naïve conditions. (D) D-APV (100 $\mu M)$ significantly 881 reduced the $5^{\text {th }}$ peak (P5) of CaTs (baseline $0.155 \pm 0.04$, D-APV $0.138 \pm 0.03, \mathrm{n}=13$ boutons, 88210 animals; baseline vs D-APV, $p=0.00642$, Wilcoxon Signed Ranks test). (E) In naïve 883 conditions P5 of CaTs is stable (baseline $0.104 \pm 0.026$, naïve $0.105 \pm 0.026, n=12$ boutons, 88410 animals; baseline vs naïve, $p=0.255$, Wilcoxon Signed Ranks test). The first peak (P1) of 885 CaTs is not affected by D-APV (baseline $0.05 \pm 0.017$; D-APV $0.047 \pm 0.014$; baseline vs D886 APV, $p=0.485$, Wilcoxon Signed Ranks test) and is stable in naïve conditions (baseline $0.033 \pm$ 8870.009 ; naïve $0.032 \pm 0.009$, baseline vs naïve, $p=0.196$, Wilcoxon Signed Ranks test). Data 888 are presented as mean \pm s.e.m. ${ }^{* *} p<0.01$. 
890 Figure 6. Uncaging glutamate induces $\mathrm{Ca}^{2+}$ rise mossy fiber boutons. (A) Representative

891 images showing dendritic spines in GCs (left) and mf boutons (right), and the associated line 892 scan analysis of calcium transients (CaTs) elicited by uncaging of MNI-glutamate (see 893 Methods), in control and Grin1-cKO animals. Blue dots indicate uncaging spots. Red Channel, 894 Alexa 594; Green Channel, Fluo-5F. (B) Line scan analysis of CaTs measuring $\Delta G / R$ in 895 dendritic spines when MNI-glutamate is uncaged in control or Grin1-cKO animals. Blue dots 896 indicate location of two photon uncaging (2PU) pulses. (C) Summary plot demonstrating a 897 significant reduction in dendritic spine CaTs in Grin1-cKO as compared to Control (control 0.053 $898 \pm 0.01 \Delta G / R, n=6$ dendritic spines, 6 animals; Grin1-cKO $0.004 \pm 0.003 \Delta G / R, n=6$ spines, 6 899 animals; $\Delta \mathrm{G} / \mathrm{R}$ control vs. Grin1-cKO, $\mathrm{p}=0.00088$, unpaired $t$-test). (D) Line scan analysis of 900 CaTs measuring $\Delta \mathrm{G} / \mathrm{R}$ in $\mathrm{mf}$ boutons when MNI-glutamate is uncaged in control or Grin1-cKO 901 animals. (E) Summary plot demonstrating significant CaTs in boutons of control as compared to 902 Grin $1-\mathrm{cKO}$ (control $0.014 \pm 0.005, \mathrm{n}=6$ boutons, 6 animals; Grin1-cKO $-0.00012 \pm-0.0006, \mathrm{n}=$ 9036 boutons, 6 animals; control vs. Grin1-cKO, $\mathrm{p}=0.015$, unpaired $t$-test). Data are presented as mean \pm s.e.m. ${ }^{*} p<0.05 ;{ }^{* * *} p<0.001$.

905

Figure 6-figure supplement 1. Grin1-cKO exhibit reduced CaTs at varying uncaging laser

907 power intensities. (A) Representative images of CaTs from control (top) and Grin1-cKO animals 908 (bottom) after MNI-glutamate uncaging (2 mM, 3 pulses at $25 \mathrm{~Hz}$ ) on $\mathrm{GC}$ dendritic spines. 909 Dotted line (yellow) indicates line scan, and blue dots indicate 2PU spots. (B) Quantified $\Delta G / R$ 910 signals (top) and uncaging induced NMDAR-EPSCs (bottom) from control and Grin1-cKO 911 animals. Blue dots indicate when 2PU pulses were delivered. (C) Control animals display robust $912 \Delta \mathrm{G} / \mathrm{R}$ signals as compared to Grin1-cKO animals at varying laser power intensities (6 spines, 6 913 animals per group, $U=0.00507$ per power intensity, Mann-Whitney test). Data are presented as 914 mean \pm s.e.m. ${ }^{* *} U<0.01$. 
916 Figure 6-figure supplement 2. Bouton CaTs can be detected after repetitive uncaging of MNI-

917 glutamate. (A) Representative images of CaTs from single-trial: 1 pulse (top) and 5 pulses, 25

$918 \mathrm{~Hz}$ (bottom) of MNI-glutamate uncaging (2 mM). Dotted line (yellow) indicates line scan, and

919 blue dots indicate 2PU spots. (B) Quantified $\Delta \mathrm{G} / \mathrm{R}$ signals from 1 pulse (black) and 5 pulses

920 (dark gray) from all trials. (C) Repetitive pulses result in larger $\Delta \mathrm{G} / \mathrm{R}$ signals as compared to 921 single pulses ( $n=6$ boutons, 6 animals, $p=0.03603$, Wilcoxon-Signed Ranks test). Data are 922 presented as mean \pm s.e.m. * $p<0.05$.

924 Figure 6-figure supplement 3. NMDAR antagonism with D-APV blocks CaTs elicited by 925 glutamate 2PU. (A) Representative image of baseline glutamate uncaging driven CaTs in mf 926 boutons (top). D-APV application (100 $\mu \mathrm{M})$ blocks CaTs (bottom). (B) Quantified $\Delta \mathrm{G} / \mathrm{R}$ signals 927 before and after D-APV application. (C) Summary data of D-APV block on glutamate uncaging 928 elicited CaTs (baseline $0.0103 \pm 0.0016$, D-APV $-0.004 \pm 0.0024, n=4$ boutons, 3 animals; $U=$ 929 0.0304, Mann-Whitney test, baseline vs D-APV). Data are presented as mean \pm s.e.m. ${ }^{*} U<$ $930 \quad 0.05$

Figure 7. preNMDARs contribute significantly to BDNF release following repetitive activity. (A) Representative images showing expression of BDNF-pHluorin in the DG and CA3

934 area (arrows indicate $\mathrm{mf}$ axon, arrowheads indicate mf boutons). Control images (top), Grin1935 cKO images (bottom). (B) Representative images of BDNF-pHluorin signal intensity at baseline 936 and after repetitive stimulation of $\mathrm{mfs}(125$ pulses, $25 \mathrm{~Hz}, \mathrm{x} 2$ ). Control images (left), Grin1-cKO 937 images (right), arrowhead indicates region of interest. (C) Time course of BDNF-pHluorin signal 938 intensity measured as $\Delta \mathrm{F} / \mathrm{F}$ (\%): control (black), Grin1-cKO (red), Naïve (blue). (D) 939 Quantification of BDNF-pHluorin signal in (C) during the last 100 seconds reveals larger BDNF 940 release in control animals as compared to Grin1-cKO (control $-18 \% \pm 3 \%, n=9$ slices, 5 
941 animals; Grin1-cKO $-8 \pm 1 \%, \mathrm{n}=10$ slices, 5 animals; Grin1-cKO vs. control, $\mathrm{p}=0.00648$,

942 unpaired $t$-test). Data are presented as mean \pm s.e.m. ${ }^{* *} p<0.01$.

943

944 Figure 7-figure supplement 1. preNMDARs contribute significantly to BDNF release following

945 a more physiological pattern of burst-stimulation. (A) Representative images of BDNF-pHluorin

946 signal intensity at baseline and after burst stimulation of mfs ( 5 pulses, $100 \mathrm{~Hz}, \mathrm{x} 50$, every 0.5

947 s). Control images (left), Grin1-cKO images (right), arrowhead indicates region of interest. (B)

948 Time course of BDNF-pHluorin signal intensity measured as $\Delta F / F$ (\%): control (black), Grin1-

949 cKO (red), Naïve (blue). (C) Quantification of BDNF-pHluorin signal in (B) during the last 100

950 seconds reveals larger BDNF release in control animals as compared to Grin1-cKO (control -

$9518.9 \% \pm 2 \%, \mathrm{n}=7$ slices, 5 animals; Grin1-cKO $-3.5 \pm 1 \%, \mathrm{n}=11$ slices, 5 animals; Grin1-cKO

952 vs. control, $\mathrm{p}=0.0305$, unpaired $t$-test). Data are presented as mean \pm s.e.m. ${ }^{*} \mathrm{p}<0.05$.

953

954 Figure 8. preNMDARs contribute to synaptic facilitation of mossy fiber inputs onto

mossy cells but not onto CA3 inhibitory interneurons. (A) Representative images showing a

CA3 interneuron and a hilar mossy cell patch-loaded with Alexa 594 (35 $\mu \mathrm{M})$ for morphological

957 identification in acute rat hippocampal slices. (B) AMPAR-EPSCs were recorded from CA3

958 interneurons at $\mathrm{V}_{\mathrm{h}}=-65 \mathrm{mV}$ and burst-stimulation was elicited by 5 pulses at $25 \mathrm{~Hz}$, see traces

959 (top). Representative experiment (bottom, left), and summary plots (right) showing bath-

960 application of MK-801 (50 $\mathrm{MM}$ ) had no significant effect on depression (top, right) or facilitation

961 (bottom, right) measured by P5/P1 ratio (baseline $54 \pm 12 \%$, MK-801 $60 \pm 16 \%, n=6$ cells; MK-

962801 vs baseline, $p=0.675$, Wilcoxon Signed Ranks test; baseline $281 \pm 30 \%$, MK-801 $318 \pm$

$96337 \%, n=7$ cells; MK-801 vs baseline, $p=0.178$, paired $t$-test, 5 animals in each data set). (C)

964 AMPAR-ESPCs were recorded at $V_{h}=-70 \mathrm{mV}$ from hilar mossy cells, LFF was induced by

965 stepping stimulation frequency from 0.1 to $1 \mathrm{~Hz}$, see traces (top). Representative experiment

966 (middle), normalized LFF and summary plot (bottom) indicating bath-application of MK-801 (50 
$967 \mu \mathrm{M}$ ) reduced facilitation (baseline $339 \pm 41 \%$, MK-801 $258 \pm 29 \%, \mathrm{n}=10$ cells, 6 animals;

968 baseline vs MK-801, $\mathrm{p}=0.00152$, paired $t$-test). DCG-IV $(1 \mu \mathrm{M})$ was applied at the end of all

969 experiments. Data are presented as mean \pm s.e.m. ${ }^{* * *} p<0.005$.

970

971 Figure 8-figure supplement 1 . Stability experiments for mf-Interneuron and mf-mossy cell

972 short-term plasticity. (A) Stable CA3 interneuron burst-induced facilitation of mf-CA3

973 transmission (baseline $273 \pm 30 \%$, naïve $294 \pm 33 \%, \mathrm{n}=10$ cells, 6 animals; $\mathrm{p}=0.298$, paired $t$ -

974 test, baseline vs naïve). (B) Stable low-frequency facilitation (LFF) of AMPAR-EPSCs in hilar

975 mossy cells (baseline $288 \pm 51 \%$, naïve $291 \pm 29 \%, n=7$ cells, 6 animals; $p=0.937$, paired $t$ -

976 test, baseline vs naïve). DCG-IV $(1 \mu \mathrm{M})$ was applied at the end of all recordings to confirm mf-

977 CA3 transmission. Data are presented as mean \pm s.e.m.

978

979

980

981

982

983

984

985

986

987

988

989

990

991

992 
bioRxiv preprint doi: https://doi.org/10.1101/2021.01.21.427714; this version posted May 11, 2021. The copyright holder for this preprint (which

was not certified by peer review) is the author/funder, who has granted bioRxiv a license to display the preprint in perpetuity. It is made available under aCC-BY 4.0 International license. 
995

996

997

998

999

1000

1001

1002

1003

1004

1005

1006

1007

1008

1009

1010

1011

1012

1013

1014

1015

1016

1017

1018

1019

1020

1021

1022

1023

1024

1025

1026

1027

1028

1029

1030

1031

1032

1033

1034

1035

1036

1037

1038

1039

1040

1041

1042

1043

1044

1045

\section{REFERENCES}

Abbott, L. F., \& Regehr, W. G. (2004). Synaptic computation. Nature, 431(7010), 796-803. doi:10.1038/nature03010

Abrahamsson, T., Chou, C. Y. C., Li, S. Y., Mancino, A., Costa, R. P., Brock, J. A., . . Sjostrom, P. J. (2017). Differential Regulation of Evoked and Spontaneous Release by Presynaptic NMDA Receptors. Neuron, 96(4), 839-855 e835. doi:10.1016/j.neuron.2017.09.030

Alle, H., \& Geiger, J. R. (2006). Combined analog and action potential coding in hippocampal mossy fibers. Science, 311(5765), 1290-1293. doi:10.1126/science.1119055

Amaral, D. G., \& Dent, J. A. (1981). Development of the mossy fibers of the dentate gyrus: I. A light and electron microscopic study of the mossy fibers and their expansions. $J$ Comp Neurol, 195(1), 51-86. doi:10.1002/cne.901950106

Amaral, D. G., Scharfman, H. E., \& Lavenex, P. (2007). The dentate gyrus: fundamental neuroanatomical organization (dentate gyrus for dummies). Prog Brain Res, 163, 3-22. doi:S0079-6123(07)63001-5 [pii]

10.1016/S0079-6123(07)63001-5

Banerjee, A., Larsen, R. S., Philpot, B. D., \& Paulsen, O. (2016). Roles of Presynaptic NMDA Receptors in Neurotransmission and Plasticity. Trends Neurosci, 39(1), 26-39. doi:10.1016/j.tins.2015.11.001

Berg, L. K., Larsson, M., Morland, C., \& Gundersen, V. (2013). Pre- and postsynaptic localization of NMDA receptor subunits at hippocampal mossy fibre synapses. Neuroscience, 230, 139-150. doi:10.1016/j.neuroscience.2012.10.061

Berretta, N., \& Jones, R. S. (1996). Tonic facilitation of glutamate release by presynaptic Nmethyl-D-aspartate autoreceptors in the entorhinal cortex. Neuroscience, 75(2), 339344. doi:10.1016/0306-4522(96)00301-6

Bischofberger, J., Engel, D., Frotscher, M., \& Jonas, P. (2006). Timing and efficacy of transmitter release at mossy fiber synapses in the hippocampal network. Pflugers Arch, 453(3), 361372. doi:10.1007/s00424-006-0093-2

Bouvier, G., Bidoret, C., Casado, M., \& Paoletti, P. (2015). Presynaptic NMDA receptors: Roles and rules. Neuroscience, 311, 322-340. doi:10.1016/j.neuroscience.2015.10.033

Bouvier, G., Higgins, D., Spolidoro, M., Carrel, D., Mathieu, B., Lena, C., . . Casado, M. (2016). Burst-Dependent Bidirectional Plasticity in the Cerebellum Is Driven by Presynaptic NMDA Receptors. Cell Rep, 15(1), 104-116. doi:10.1016/j.celrep.2016.03.004

Bouvier, G., Larsen, R. S., Rodriguez-Moreno, A., Paulsen, O., \& Sjostrom, P. J. (2018). Towards resolving the presynaptic NMDA receptor debate. Curr Opin Neurobiol, 51, 1-7. doi:10.1016/j.conb.2017.12.020

Buchanan, K. A., Blackman, A. V., Moreau, A. W., Elgar, D., Costa, R. P., Lalanne, T., . . . Sjostrom, P. J. (2012). Target-specific expression of presynaptic NMDA receptors in neocortical microcircuits. Neuron, 75(3), 451-466. doi:10.1016/j.neuron.2012.06.017

Burke, K. J., Jr., \& Bender, K. J. (2019). Modulation of lon Channels in the Axon: Mechanisms and Function. Front Cell Neurosci, 13, 221. doi:10.3389/fncel.2019.00221

Carter, B. C., \& Jahr, C. E. (2016). Postsynaptic, not presynaptic NMDA receptors are required for spike-timing-dependent LTD induction. Nat Neurosci, 19(9), 1218-1224. doi:10.1038/nn.4343

Castillo, P. E. (2012). Presynaptic LTP and LTD of excitatory and inhibitory synapses. Cold Spring Harb Perspect Biol, 4(2). doi:10.1101/cshperspect.a005728

Castillo, P. E., Malenka, R. C., \& Nicoll, R. A. (1997). Kainate receptors mediate a slow postsynaptic current in hippocampal CA3 neurons. Nature, 388(6638), 182-186. doi:10.1038/40645

Chamberland, S., Timofeeva, Y., Evstratova, A., Volynski, K., \& Toth, K. (2018). Action potential counting at giant mossy fiber terminals gates information transfer in the hippocampus. 
1046

1047

1048

1049

1050

1051

1052

1053

1054

1055

1056

1057

1058

1059

1060

1061

1062

1063

1064

1065

1066

1067

1068

1069

1070

1071

1072

1073

1074

1075

1076

1077

1078

1079

1080

1081

1082

1083

1084

1085

1086

1087

1088

1089

1090

1091

1092

1093

1094

1095

1096

Proc Natl Acad Sci U S A, 115(28), 7434-7439. doi:10.1073/pnas.1720659115

Chen, W., Walwyn, W., Ennes, H. S., Kim, H., McRoberts, J. A., \& Marvizon, J. C. (2014). BDNF released during neuropathic pain potentiates NMDA receptors in primary afferent terminals. Eur J Neurosci, 39(9), 1439-1454. doi:10.1111/ejn.12516

Chen, Y., Chen, S. R., Chen, H., Zhang, J., \& Pan, H. L. (2019). Increased alpha2delta-1-NMDA receptor coupling potentiates glutamatergic input to spinal dorsal horn neurons in chemotherapy-induced neuropathic pain. J Neurochem, 148(2), 252-274. doi:10.1111/jnc.14627

Christie, J. M., \& Jahr, C. E. (2008). Dendritic NMDA receptors activate axonal calcium channels. Neuron, 60(2), 298-307. doi:10.1016/j.neuron.2008.08.028

Christie, J. M., \& Jahr, C. E. (2009). Selective expression of ligand-gated ion channels in L5 pyramidal cell axons. J Neurosci, 29(37), 11441-11450. doi:10.1523/JNEUROSCI.238709.2009

Conner, J. M., Lauterborn, J. C., Yan, Q., Gall, C. M., \& Varon, S. (1997). Distribution of brainderived neurotrophic factor (BDNF) protein and mRNA in the normal adult rat CNS: evidence for anterograde axonal transport. J Neurosci, 17(7), 2295-2313. Retrieved from https://www.ncbi.nlm.nih.gov/pubmed/9065491

Corlew, R., Brasier, D. J., Feldman, D. E., \& Philpot, B. D. (2008). Presynaptic NMDA receptors: newly appreciated roles in cortical synaptic function and plasticity. Neuroscientist, 14(6), 609-625. doi:10.1177/1073858408322675

Corlew, R., Wang, Y., Ghermazien, H., Erisir, A., \& Philpot, B. D. (2007). Developmental switch in the contribution of presynaptic and postsynaptic NMDA receptors to long-term depression. J Neurosci, 27(37), 9835-9845. doi:10.1523/JNEUROSCI.5494-06.2007

Cull-Candy, S., Brickley, S., \& Farrant, M. (2001). NMDA receptor subunits: diversity, development and disease. Curr Opin Neurobiol, 11(3), 327-335. Retrieved from https://www.ncbi.nlm.nih.gov/pubmed/11399431

Diamantaki, M., Frey, M., Berens, P., Preston-Ferrer, P., \& Burgalossi, A. (2016). Sparse activity of identified dentate granule cells during spatial exploration. Elife, 5. doi:10.7554/eLife.20252

Dore, K., Aow, J., \& Malinow, R. (2016). The Emergence of NMDA Receptor Metabotropic Function: Insights from Imaging. Front Synaptic Neurosci, 8, 20. doi:10.3389/fnsyn.2016.00020

Duguid, I. C. (2013). Presynaptic NMDA receptors: are they dendritic receptors in disguise? Brain Res Bull, 93, 4-9. doi:10.1016/j.brainresbull.2012.12.004

Duguid, I. C., \& Smart, T. G. (2009). Presynaptic NMDA Receptors. In A. M. Van Dongen (Ed.), Biology of the NMDA Receptor. Boca Raton (FL).

Engelman, H. S., \& MacDermott, A. B. (2004). Presynaptic ionotropic receptors and control of transmitter release. Nat Rev Neurosci, 5(2), 135-145. doi:10.1038/nrn1297

Evstratova, A., \& Toth, K. (2014). Information processing and synaptic plasticity at hippocampal mossy fiber terminals. Front Cell Neurosci, 8, 28. doi:10.3389/fncel.2014.00028

Fujisawa, S., \& Aoki, C. (2003). In vivo blockade of N-methyl-D-aspartate receptors induces rapid trafficking of NR2B subunits away from synapses and out of spines and terminals in adult cortex. Neuroscience, 121(1), 51-63. doi:10.1016/s0306-4522(03)00341-5

Gill, I., Droubi, S., Giovedi, S., Fedder, K. N., Bury, L. A., Bosco, F., . . Sabo, S. L. (2015). Presynaptic NMDA receptors - dynamics and distribution in developing axons in vitro and in vivo. J Cell Sci, 128(4), 768-780. doi:10.1242/jcs.162362

GoodSmith, D., Chen, X., Wang, C., Kim, S. H., Song, H., Burgalossi, A., . . Knierim, J. J. (2017). Spatial Representations of Granule Cells and Mossy Cells of the Dentate Gyrus. Neuron, 93(3), 677-690 e675. doi:10.1016/j.neuron.2016.12.026

Hagena, H., \& Manahan-Vaughan, D. (2010). Frequency facilitation at mossy fiber-CA3 synapses of freely behaving rats contributes to the induction of persistent LTD via an 
adenosine-A1 receptor-regulated mechanism. Cereb Cortex, 20(5), 1121-1130. doi:10.1093/cercor/bhp184

Henze, D. A., Urban, N. N., \& Barrionuevo, G. (2000). The multifarious hippocampal mossy fiber pathway: a review. Neuroscience, 98(3), 407-427. Retrieved from https://www.ncbi.nlm.nih.gov/pubmed/10869836

Henze, D. A., Wittner, L., \& Buzsaki, G. (2002). Single granule cells reliably discharge targets in the hippocampal CA3 network in vivo. Nat Neurosci, 5(8), 790-795. doi:10.1038/nn887

Jackman, S. L., \& Regehr, W. G. (2017). The Mechanisms and Functions of Synaptic Facilitation. Neuron, 94(3), 447-464. doi:10.1016/j.neuron.2017.02.047

Jourdain, P., Bergersen, L. H., Bhaukaurally, K., Bezzi, P., Santello, M., Domercq, M., . . . Volterra, A. (2007). Glutamate exocytosis from astrocytes controls synaptic strength. Nat Neurosci, 10(3), 331-339. doi:10.1038/nn1849

Kamiya, H., Shinozaki, H., \& Yamamoto, C. (1996). Activation of metabotropic glutamate receptor type $2 / 3$ suppresses transmission at rat hippocampal mossy fibre synapses. $J$ Physiol, 493 ( Pt 2), 447-455. doi:10.1113/jphysiol.1996.sp021395

Klug, A., Borst, J. G., Carlson, B. A., Kopp-Scheinpflug, C., Klyachko, V. A., \& Xu-Friedman, M. A. (2012). How do short-term changes at synapses fine-tune information processing? $J$ Neurosci, 32(41), 14058-14063. doi:10.1523/JNEUROSCI.3348-12.2012

Kunz, P. A., Roberts, A. C., \& Philpot, B. D. (2013). Presynaptic NMDA receptor mechanisms for enhancing spontaneous neurotransmitter release. J Neurosci, 33(18), 7762-7769. doi:10.1523/JNEUROSCI.2482-12.2013

Kwon, H. B., \& Castillo, P. E. (2008). Role of glutamate autoreceptors at hippocampal mossy fiber synapses. Neuron, 60(6), 1082-1094. doi:10.1016/j.neuron.2008.10.045

Larsen, R. S., Corlew, R. J., Henson, M. A., Roberts, A. C., Mishina, M., Watanabe, M., ... . Philpot, B. D. (2011). NR3A-containing NMDARs promote neurotransmitter release and spike timing-dependent plasticity. Nat Neurosci, 14(3), 338-344. doi:10.1038/nn.2750

Larsen, R. S., \& Sjostrom, P. J. (2015). Synapse-type-specific plasticity in local circuits. Curr Opin Neurobiol, 35, 127-135. doi:10.1016/j.conb.2015.08.001

Larsen, R. S., Smith, I. T., Miriyala, J., Han, J. E., Corlew, R. J., Smith, S. L., \& Philpot, B. D. (2014). Synapse-specific control of experience-dependent plasticity by presynaptic NMDA receptors. Neuron, 83(4), 879-893. doi:10.1016/j.neuron.2014.07.039

Lau, C. G., \& Zukin, R. S. (2007). NMDA receptor trafficking in synaptic plasticity and neuropsychiatric disorders. Nat Rev Neurosci, 8(6), 413-426. doi:10.1038/nrn2153

Lawrence, J. J., \& McBain, C. J. (2003). Interneuron diversity series: containing the detonation-feedforward inhibition in the CA3 hippocampus. Trends Neurosci, 26(11), 631-640. doi:10.1016/j.tins.2003.09.007

Liang, Y., Yuan, L. L., Johnston, D., \& Gray, R. (2002). Calcium signaling at single mossy fiber presynaptic terminals in the rat hippocampus. J Neurophysiol, 87(2), 1132-1137. doi:10.1152/jn.00661.2001

Lujan, R., Nusser, Z., Roberts, J. D., Shigemoto, R., \& Somogyi, P. (1996). Perisynaptic location of metabotropic glutamate receptors mGluR1 and mGluR5 on dendrites and dendritic spines in the rat hippocampus. Eur $J$ Neurosci, 8(7), 1488-1500. Retrieved from https://www.ncbi.nlm.nih.gov/pubmed/8758956

Lysetskiy, M., Foldy, C., \& Soltesz, I. (2005). Long- and short-term plasticity at mossy fiber synapses on mossy cells in the rat dentate gyrus. Hippocampus, 15(6), 691-696. doi:10.1002/hipo.20096

Madara, J. C., \& Levine, E. S. (2008). Presynaptic and postsynaptic NMDA receptors mediate distinct effects of brain-derived neurotrophic factor on synaptic transmission. $J$ Neurophysiol, 100(6), 3175-3184. doi:10.1152/jn.90880.2008

Mameli, M., Carta, M., Partridge, L. D., \& Valenzuela, C. F. (2005). Neurosteroid-induced plasticity of immature synapses via retrograde modulation of presynaptic NMDA 
receptors. J Neurosci, 25(9), 2285-2294. doi:10.1523/JNEUROSCI.3877-04.2005

Martin, D., Bustos, G. A., Bowe, M. A., Bray, S. D., \& Nadler, J. V. (1991). Autoreceptor regulation of glutamate and aspartate release from slices of the hippocampal CA1 area. $J$ Neurochem, 56(5), 1647-1655. doi:10.1111/j.1471-4159.1991.tb02063.x

McGuinness, L., Taylor, C., Taylor, R. D., Yau, C., Langenhan, T., Hart, M. L., . . Emptage, N. J. (2010). Presynaptic NMDARs in the hippocampus facilitate transmitter release at theta frequency. Neuron, 68(6), 1109-1127. doi:10.1016/j.neuron.2010.11.023

McHugh, T. J., Jones, M. W., Quinn, J. J., Balthasar, N., Coppari, R., Elmquist, J. K., . . . Tonegawa, S. (2007). Dentate gyrus NMDA receptors mediate rapid pattern separation in the hippocampal network. Science, 317(5834), 94-99. doi:10.1126/science.1140263

McNamara, J. O., \& Scharfman, H. E. (2012). Temporal Lobe Epilepsy and the BDNF Receptor, TrkB. In th, J. L. Noebels, M. Avoli, M. A. Rogawski, R. W. Olsen, \& A. V. DelgadoEscueta (Eds.), Jasper's Basic Mechanisms of the Epilepsies. Bethesda (MD).

Miller, R. J. (1998). Presynaptic receptors. Annu Rev Pharmacol Toxicol, 38, 201-227. doi:10.1146/annurev.pharmtox.38.1.201

Nicoll, R. A., \& Schmitz, D. (2005). Synaptic plasticity at hippocampal mossy fibre synapses. Nat Rev Neurosci, 6(11), 863-876. doi:10.1038/nrn1786

Nusser, Z., Lujan, R., Laube, G., Roberts, J. D., Molnar, E., \& Somogyi, P. (1998). Cell type and pathway dependence of synaptic AMPA receptor number and variability in the hippocampus. Neuron, 21(3), 545-559. Retrieved from https://www.ncbi.nlm.nih.gov/pubmed/9768841

Paoletti, P., Bellone, C., \& Zhou, Q. (2013). NMDA receptor subunit diversity: impact on receptor properties, synaptic plasticity and disease. Nat Rev Neurosci, 14(6), 383-400. doi:10.1038/nrn3504

Park, H., Popescu, A., \& Poo, M. M. (2014). Essential role of presynaptic NMDA receptors in activity-dependent BDNF secretion and corticostriatal LTP. Neuron, 84(5), 1009-1022. doi:10.1016/j.neuron.2014.10.045

Pernia-Andrade, A. J., \& Jonas, P. (2014). Theta-gamma-modulated synaptic currents in hippocampal granule cells in vivo define a mechanism for network oscillations. Neuron, 81(1), 140-152. doi:10.1016/j.neuron.2013.09.046

Petralia, R. S., Yokotani, N., \& Wenthold, R. J. (1994). Light and electron microscope distribution of the NMDA receptor subunit NMDAR1 in the rat nervous system using a selective anti-peptide antibody. J Neurosci, 14(2), 667-696. Retrieved from https://www.ncbi.nlm.nih.gov/pubmed/8301357

Pickel, V. M., Colago, E. E., Mania, I., Molosh, A. I., \& Rainnie, D. G. (2006). Dopamine D1 receptors co-distribute with $\mathrm{N}$-methyl-D-aspartic acid type-1 subunits and modulate synaptically-evoked $\mathrm{N}$-methyl-D-aspartic acid currents in rat basolateral amygdala. Neuroscience, 142(3), 671-690. doi:10.1016/j.neuroscience.2006.06.059

Pinheiro, P. S., \& Mulle, C. (2008). Presynaptic glutamate receptors: physiological functions and mechanisms of action. Nat Rev Neurosci, 9(6), 423-436. doi:10.1038/nrn2379

Rebola, N., Carta, M., \& Mulle, C. (2017). Operation and plasticity of hippocampal CA3 circuits: implications for memory encoding. Nat Rev Neurosci, 18(4), 208-220. doi:10.1038/nrn.2017.10

Rogers, M., \& Dani, J. A. (1995). Comparison of quantitative calcium flux through NMDA, ATP, and ACh receptor channels. Biophys J, 68(2), 501-506. doi:10.1016/S00063495(95)80211-0

Rossi, B., Ogden, D., Llano, I., Tan, Y. P., Marty, A., \& Collin, T. (2012). Current and calcium responses to local activation of axonal NMDA receptors in developing cerebellar molecular layer interneurons. PLoS One, 7(6), e39983. doi:10.1371/journal.pone.0039983

Salin, P. A., Scanziani, M., Malenka, R. C., \& Nicoll, R. A. (1996). Distinct short-term plasticity at 
1238

1239

1240

1241

1242

1243

1244

1245

1246

1247

1248

1249

two excitatory synapses in the hippocampus. Proc Natl Acad Sci U S A, 93(23), 1330413309. Retrieved from https://www.ncbi.nlm.nih.gov/pubmed/8917586

Sanz-Clemente, A., Nicoll, R. A., \& Roche, K. W. (2013). Diversity in NMDA receptor composition: many regulators, many consequences. Neuroscientist, 19(1), 62-75. doi:10.1177/1073858411435129

Savtchouk, I., Di Castro, M. A., Ali, R., Stubbe, H., Lujan, R., \& Volterra, A. (2019). Circuitspecific control of the medial entorhinal inputs to the dentate gyrus by atypical presynaptic NMDARs activated by astrocytes. Proc Natl Acad Sci U S A, 116(27), 13602-13610. doi:10.1073/pnas.1816013116

Schicker, K. W., Dorostkar, M. M., \& Boehm, S. (2008). Modulation of transmitter release via presynaptic ligand-gated ion channels. Curr Mol Pharmacol, 1(2), 106-129. doi:10.2174/1874467210801020106

Schildt, S., Endres, T., Lessmann, V., \& Edelmann, E. (2013). Acute and chronic interference with BDNF/TrkB-signaling impair LTP selectively at mossy fiber synapses in the CA3 region of mouse hippocampus. Neuropharmacology, 71, 247-254. doi:10.1016/j.neuropharm.2013.03.041

Senzai, Y., \& Buzsaki, G. (2017). Physiological Properties and Behavioral Correlates of Hippocampal Granule Cells and Mossy Cells. Neuron, 93(3), 691-704 e695. doi:10.1016/j.neuron.2016.12.011

Siegel, S. J., Brose, N., Janssen, W. G., Gasic, G. P., Jahn, R., Heinemann, S. F., \& Morrison, J. $\mathrm{H}$. (1994). Regional, cellular, and ultrastructural distribution of N-methyl-D-aspartate receptor subunit 1 in monkey hippocampus. Proc Natl Acad Sci U S A, 91(2), 564-568. Retrieved from https://www.ncbi.nlm.nih.gov/pubmed/8290563

Takumi, Y., Ramirez-Leon, V., Laake, P., Rinvik, E., \& Ottersen, O. P. (1999). Different modes of expression of AMPA and NMDA receptors in hippocampal synapses. Nat Neurosci, 2(7), 618-624. doi:10.1038/10172

Toni, N., \& Schinder, A. F. (2015). Maturation and Functional Integration of New Granule Cells into the Adult Hippocampus. Cold Spring Harb Perspect Biol, 8(1), a018903. doi:10.1101/cshperspect.a018903

Toth, K., Suares, G., Lawrence, J. J., Philips-Tansey, E., \& McBain, C. J. (2000). Differential mechanisms of transmission at three types of mossy fiber synapse. J Neurosci, 20(22), 8279-8289. Retrieved from https://www.ncbi.nlm.nih.gov/pubmed/11069934

Traynelis, S. F., Wollmuth, L. P., McBain, C. J., Menniti, F. S., Vance, K. M., Ogden, K. K., . . . Dingledine, R. (2010). Glutamate receptor ion channels: structure, regulation, and function. Pharmacol Rev, 62(3), 405-496. doi:10.1124/pr.109.002451

Vandael, D., Borges-Merjane, C., Zhang, X., \& Jonas, P. (2020). Short-Term Plasticity at Hippocampal Mossy Fiber Synapses Is Induced by Natural Activity Patterns and Associated with Vesicle Pool Engram Formation. Neuron, 107(3), 509-521 e507. doi:10.1016/j.neuron.2020.05.013

Vyleta, N. P., Borges-Merjane, C., \& Jonas, P. (2016). Plasticity-dependent, full detonation at hippocampal mossy fiber-CA3 pyramidal neuron synapses. Elife, 5. doi:10.7554/eLife.17977

Wang, P. Y., Petralia, R. S., Wang, Y. X., Wenthold, R. J., \& Brenowitz, S. D. (2011). Functional NMDA receptors at axonal growth cones of young hippocampal neurons. J Neurosci, 31(25), 9289-9297. doi:10.1523/JNEUROSCI.5639-10.2011

Watanabe, M., Fukaya, M., Sakimura, K., Manabe, T., Mishina, M., \& Inoue, Y. (1998). Selective scarcity of NMDA receptor channel subunits in the stratum lucidum (mossy fibrerecipient layer) of the mouse hippocampal CA3 subfield. Eur J Neurosci, 10(2), 478-487. Retrieved from https://www.ncbi.nlm.nih.gov/pubmed/9749710

Wong, H. H., Rannio, S., Jones, V., Thomazeau, A., \& Sjostrom, P. J. (2020). NMDA receptors in axons: there's no coincidence. J Physiol. doi:10.1113/JP280059 
1250

1251

1252

1253

1254

1255

1256

1257

1258

1259

1260

1261

1262

1263

1264

1265

1266

1267

1268

1269
Woodhall, G., Evans, D. I., Cunningham, M. O., \& Jones, R. S. (2001). NR2B-containing NMDA autoreceptors at synapses on entorhinal cortical neurons. J Neurophysiol, 86(4), 16441651. doi:10.1152/jn.2001.86.4.1644

Yan, Q., Rosenfeld, R. D., Matheson, C. R., Hawkins, N., Lopez, O. T., Bennett, L., \& Welcher, A. A. (1997). Expression of brain-derived neurotrophic factor protein in the adult rat central nervous system. Neuroscience, 78(2), 431-448. Retrieved from https://www.ncbi.nlm.nih.gov/pubmed/9145800

Yang, J., Woodhall, G. L., \& Jones, R. S. (2006). Tonic facilitation of glutamate release by presynaptic NR2B-containing NMDA receptors is increased in the entorhinal cortex of chronically epileptic rats. J Neurosci, 26(2), 406-410. doi:10.1523/JNEUROSCI.441305.2006

Zeng, J., Thomson, L. M., Aicher, S. A., \& Terman, G. W. (2006). Primary afferent NMDA receptors increase dorsal horn excitation and mediate opiate tolerance in neonatal rats. J Neurosci, 26(46), 12033-12042. doi:10.1523/JNEUROSCI.2530-06.2006

Zucca, S., Griguoli, M., Malezieux, M., Grosjean, N., Carta, M., \& Mulle, C. (2017). Control of Spike Transfer at Hippocampal Mossy Fiber Synapses In Vivo by GABAA and GABAB Receptor-Mediated Inhibition. J Neurosci, 37(3), 587-598. doi:10.1523/JNEUROSCI.2057-16.2016 


\begin{tabular}{|c|c|c|c|c|}
\hline \multicolumn{5}{|c|}{ Key Resources Table } \\
\hline $\begin{array}{l}\text { Reagent } \\
\text { type } \\
\text { (species) } \\
\text { or } \\
\text { resource }\end{array}$ & Designation & $\begin{array}{l}\text { Source or } \\
\text { reference }\end{array}$ & Identifiers & $\begin{array}{l}\text { Additional } \\
\text { information }\end{array}$ \\
\hline $\begin{array}{l}\text { strain, } \\
\text { strain } \\
\text { background } \\
\text { (rattus } \\
\text { norvegicus } \\
\text { male and } \\
\text { female) }\end{array}$ & $\begin{array}{l}\text { Rat: Sprague- } \\
\text { Dawley }\end{array}$ & Charles River & Strain code: 400 & \\
\hline $\begin{array}{l}\text { strain, } \\
\text { strain } \\
\text { background } \\
\text { (Mus } \\
\text { musculus, } \\
\text { male and } \\
\text { female) }\end{array}$ & 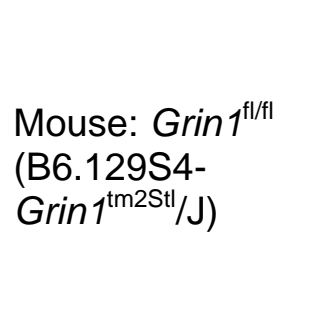 & $\begin{array}{l}\text { Dr. Michael } \\
\text { Higley /The } \\
\text { Jackson } \\
\text { Laboratory }\end{array}$ & $\begin{array}{l}\text { RRID: IMSR_JAX: } \\
005246\end{array}$ & \\
\hline $\begin{array}{l}\text { strain, } \\
\text { strain } \\
\text { background } \\
\text { (Mus } \\
\text { musculus } \\
\text { male and } \\
\text { female) }\end{array}$ & Mouse: C57BI6/J & Charles River & Strain code: 027 & \\
\hline antibody & $\begin{array}{l}\text { (Include host } \\
\text { species and } \\
\text { clonality) } \\
\text { Mouse, } \\
\text { Monoclonal, anti- } \\
\text { NMDAR1 }\end{array}$ & Millipore & Cat\# MAB363 & $10 \mu \mathrm{g} / \mathrm{mL}$ \\
\hline antibody & $\begin{array}{l}\text { Rabbit, } \\
\text { Polyclonal, anti- } \\
\text { GluA1-4, (pan- } \\
\text { AMPA) }\end{array}$ & $\begin{array}{l}\text { Dr. Elek } \\
\text { Molnar } \\
\text { /Bristol } \\
\text { University }\end{array}$ & $\begin{array}{l}\text { Generated by Dr. } \\
\text { Elek Molnar }\end{array}$ & $10 \mu \mathrm{g} / \mathrm{mL}$ \\
\hline antibody & $\begin{array}{l}\text { Goat anti-rabbit } \\
\text { lgG conjugated } \\
\text { gold particles }\end{array}$ & $\begin{array}{l}\text { Nanoprobes } \\
\text { Inc }\end{array}$ & \#2003-0.5ML & $(1: 100)$ \\
\hline
\end{tabular}




\begin{tabular}{|c|c|c|c|c|}
\hline $\begin{array}{l}\text { recombinan } \\
\text { t DNA } \\
\text { reagent }\end{array}$ & $\begin{array}{l}\text { AAV5-CamKII- } \\
\text { GFP-Cre }\end{array}$ & $\begin{array}{l}\text { Penn Vector } \\
\text { Core }\end{array}$ & AV-5-PV2521 & $\begin{array}{l}\text { Available on } \\
\text { Addgene }\end{array}$ \\
\hline $\begin{array}{l}\text { recombinan } \\
\text { t DNA } \\
\text { reagent }\end{array}$ & $\begin{array}{l}\text { AAV5-CamKII- } \\
\text { eGFP }\end{array}$ & $\begin{array}{l}\text { Penn Vector } \\
\text { Core }\end{array}$ & AV-5-PV1917 & $\begin{array}{l}\text { Available on } \\
\text { Addgene }\end{array}$ \\
\hline $\begin{array}{l}\text { recombinan } \\
\text { t DNA } \\
\text { reagent }\end{array}$ & $\begin{array}{l}\text { AAV5-CamKII- } \\
\text { mcherry-Cre }\end{array}$ & $\begin{array}{l}\text { UNC Vector } \\
\text { Core }\end{array}$ & See website & $\begin{array}{l}\text { https://www } \\
\text { med. } \\
\text { unc.edu } \\
\text { /genetherapy/ } \\
\text { vectorcore/in- } \\
\text { stock-aav- } \\
\text { vectors/ }\end{array}$ \\
\hline $\begin{array}{l}\text { recombinan } \\
\text { t DNA } \\
\text { reagent }\end{array}$ & $\begin{array}{l}\text { AAV5-CamKII- } \\
\text { mcherry }\end{array}$ & $\begin{array}{l}\text { UNC Vector } \\
\text { Core-Dr. Karl } \\
\text { Deisseroth } \\
\text { Control } \\
\text { Fluorophores }\end{array}$ & See website & $\begin{array}{l}\text { https://www } \\
\text { med. } \\
\text { unc.edu } \\
\text { /genetherapy/ } \\
\text { vectorcore/in- } \\
\text { stock-aav- } \\
\text { vectors/ }\end{array}$ \\
\hline $\begin{array}{l}\text { recombinan } \\
\text { t DNA } \\
\text { reagent }\end{array}$ & $\begin{array}{l}\text { AAV-DJ-flex- } \\
\text { OChIEF- } \\
\text { tdTomato }\end{array}$ & $\begin{array}{l}\text { Dr. Pascal } \\
\text { Kaeser } \\
\text { PMID: } \\
\text { 29398114 }\end{array}$ & $\begin{array}{l}\text { Generated at UNC } \\
\text { Vector Core }\end{array}$ & Custom Order \\
\hline $\begin{array}{l}\text { recombinan } \\
\text { t DNA } \\
\text { reagent }\end{array}$ & $\begin{array}{l}\text { AAV-DJ-DIO- } \\
\text { BDNF-phluorin }\end{array}$ & $\begin{array}{l}\text { Dr. Hyungju } \\
\text { Park } \\
\text { PMID: } \\
\text { 25467984 }\end{array}$ & $\begin{array}{l}\text { Generated at UNC } \\
\text { Vector Core }\end{array}$ & Custom Order \\
\hline $\begin{array}{l}\text { chemical } \\
\text { compound, } \\
\text { drug }\end{array}$ & Ketamine & Merial & $\begin{array}{l}\text { Cat\#0366110300190 } \\
4\end{array}$ & \\
\hline $\begin{array}{l}\text { chemical } \\
\text { compound, } \\
\text { drug }\end{array}$ & Xylazine & Calier & Cat\#20100-003 & \\
\hline $\begin{array}{l}\text { chemical } \\
\text { compound, } \\
\text { drug }\end{array}$ & $\begin{array}{l}\text { Paraformaldehyd } \\
\text { e }\end{array}$ & Scharlau & PA0095 & \\
\hline
\end{tabular}




\begin{tabular}{|c|c|c|c|c|}
\hline $\begin{array}{l}\text { chemical } \\
\text { compound, } \\
\text { drug }\end{array}$ & Glutaraldehyde & $\begin{array}{l}\text { Electron } \\
\text { Microscopy } \\
\text { Sciences }\end{array}$ & Cat\#16210 & \\
\hline $\begin{array}{l}\text { chemical } \\
\text { compound, } \\
\text { drug }\end{array}$ & Picric Acid & Panreac & Cat\#141048.1609 & \\
\hline $\begin{array}{l}\text { chemical } \\
\text { compound, } \\
\text { drug }\end{array}$ & Phosphate Buffer & Scharlau & SO03321000 & \\
\hline $\begin{array}{l}\text { chemical } \\
\text { compound, } \\
\text { drug }\end{array}$ & $\begin{array}{l}\text { Human serum } \\
\text { albumin }\end{array}$ & $\begin{array}{l}\text { SigmaMillipor } \\
\mathrm{e}\end{array}$ & A-1653 & \\
\hline \multirow{2}{*}{$\begin{array}{l}\text { chemical } \\
\text { compound, } \\
\text { drug }\end{array}$} & \multirow{2}{*}{ TBS } & \multirow{2}{*}{$\begin{array}{l}\text { SigmaMillipor } \\
\mathrm{e}\end{array}$} & \multirow[t]{2}{*}{ T1503 } & \\
\hline & & & & \\
\hline $\begin{array}{l}\text { chemical } \\
\text { compound, } \\
\text { drug }\end{array}$ & Triton X-100 & $\begin{array}{l}\text { SigmaMillipor } \\
\mathrm{e}\end{array}$ & T8787 & \\
\hline $\begin{array}{l}\text { chemical } \\
\text { compound, } \\
\text { drug }\end{array}$ & $\begin{array}{l}\text { Polyethylene } \\
\text { glycol }\end{array}$ & $\begin{array}{l}\text { SigmaMillipor } \\
\mathrm{e}\end{array}$ & $25322-68-3$ & \\
\hline $\begin{array}{l}\text { chemical } \\
\text { compound, } \\
\text { drug }\end{array}$ & Uranyl acetate & $\begin{array}{l}\text { Electron } \\
\text { Microscopy } \\
\text { Sciences }\end{array}$ & Cat\#22400 & \\
\hline $\begin{array}{l}\text { chemical } \\
\text { compound, } \\
\text { drug }\end{array}$ & $\begin{array}{l}\text { Reynold's lead } \\
\text { citrate }\end{array}$ & $\begin{array}{l}\text { Electron } \\
\text { Microscopy } \\
\text { Sciences }\end{array}$ & $\# 17800$ & \\
\hline $\begin{array}{l}\text { chemical } \\
\text { compound, } \\
\text { drug }\end{array}$ & Picrotoxin & $\begin{array}{l}\text { SigmaMillipor } \\
\mathrm{e}\end{array}$ & Cat\# P1675 & \\
\hline $\begin{array}{l}\text { chemical } \\
\text { compound, } \\
\text { drug }\end{array}$ & LY303070 & $\begin{array}{l}\text { ABX } \\
\text { Chemical Co. }\end{array}$ & $\mathrm{N} / \mathrm{A}$ & Custom Order \\
\hline $\begin{array}{l}\text { chemical } \\
\text { compound, } \\
\text { drug }\end{array}$ & MK-801 & $\begin{array}{l}\text { Tocris } \\
\text { Bioscience }\end{array}$ & Cat\# 0924 & \\
\hline
\end{tabular}




\begin{tabular}{|c|c|c|c|}
\hline $\begin{array}{l}\text { chemical } \\
\text { compound, } \\
\text { drug }\end{array}$ & DCG-IV & $\begin{array}{l}\text { Tocris } \\
\text { Bioscience }\end{array}$ & Cat\# 0975 \\
\hline $\begin{array}{l}\text { chemical } \\
\text { compound, } \\
\text { drug }\end{array}$ & D-APV & $\begin{array}{l}\text { Tocris } \\
\text { Bioscience }\end{array}$ & Cat\# 0106 \\
\hline $\begin{array}{l}\text { chemical } \\
\text { compound, } \\
\text { drug }\end{array}$ & D-APV & $\begin{array}{l}\text { NIMH } \\
\text { Chemical } \\
\text { Synthesis } \\
\text { Program }\end{array}$ & $\mathrm{N} / \mathrm{A}$ \\
\hline $\begin{array}{l}\text { chemical } \\
\text { compound, } \\
\text { drug }\end{array}$ & R-CPP & $\begin{array}{l}\text { Tocris } \\
\text { Bioscience }\end{array}$ & Cat\# 0247 \\
\hline $\begin{array}{l}\text { chemical } \\
\text { compound, } \\
\text { drug }\end{array}$ & NBQX & $\begin{array}{l}\text { Cayman } \\
\text { Chemical Co. }\end{array}$ & Cat\# 14914 \\
\hline $\begin{array}{l}\text { chemical } \\
\text { compound, } \\
\text { drug }\end{array}$ & $\begin{array}{l}\text { Fluo5-F } \\
\text { pentapotassium } \\
\text { salt cell } \\
\text { impermeant }\end{array}$ & $\begin{array}{l}\text { Invitrogen } \\
\text { Molecular } \\
\text { Probes }\end{array}$ & Cat\# F14221 \\
\hline $\begin{array}{l}\text { chemical } \\
\text { compound, } \\
\text { drug }\end{array}$ & $\begin{array}{l}\text { Alexa Fluor } 594 \\
\text { Hydrazide }\end{array}$ & $\begin{array}{l}\text { Invitrogen } \\
\text { Molecular } \\
\text { Probes }\end{array}$ & Cat\# A10438 \\
\hline $\begin{array}{l}\text { chemical } \\
\text { compound, } \\
\text { drug }\end{array}$ & $\begin{array}{l}\text { Alexa Fluor } 488 \\
\text { Hydrazide }\end{array}$ & $\begin{array}{l}\text { Invitrogen } \\
\text { Molecular } \\
\text { Probes }\end{array}$ & Cat\# A10436 \\
\hline $\begin{array}{l}\text { chemical } \\
\text { compound, } \\
\text { drug }\end{array}$ & D-Serine & $\begin{array}{l}\text { Tocris } \\
\text { Bioscience }\end{array}$ & Cat\# 0226 \\
\hline $\begin{array}{l}\text { chemical } \\
\text { compound, } \\
\text { drug }\end{array}$ & $\begin{array}{l}\text { MNI-caged-L- } \\
\text { glutamate }\end{array}$ & $\begin{array}{l}\text { Tocris } \\
\text { Bioscience }\end{array}$ & Cat\# 1490 \\
\hline $\begin{array}{l}\text { chemical } \\
\text { compound, } \\
\text { drug }\end{array}$ & Sucrose & $\begin{array}{l}\text { SigmaMillipor } \\
\text { e }\end{array}$ & Cat\# S9378 \\
\hline $\begin{array}{l}\text { chemical } \\
\text { compound, } \\
\text { drug }\end{array}$ & $\mathrm{KCl}$ & $\begin{array}{l}\text { SigmaMillipor } \\
\text { e }\end{array}$ & Cat\# P3911 \\
\hline
\end{tabular}




\begin{tabular}{|c|c|c|c|}
\hline $\begin{array}{l}\text { chemical } \\
\text { compound, } \\
\text { drug }\end{array}$ & $\mathrm{NaH}_{2} \mathrm{PO}_{4}$ & $\begin{array}{l}\text { SigmaMillipor } \\
\mathrm{e}\end{array}$ & Cat\# S9638 \\
\hline $\begin{array}{l}\text { chemical } \\
\text { compound, } \\
\text { drug }\end{array}$ & $\mathrm{CaCl}_{2}$ & $\begin{array}{l}\text { SigmaMillipor } \\
\mathrm{e}\end{array}$ & Cat\# C8106 \\
\hline $\begin{array}{l}\text { chemical } \\
\text { compound, } \\
\text { drug }\end{array}$ & $\mathrm{MgCl}_{2}$ & $\begin{array}{l}\text { SigmaMillipor } \\
\text { e }\end{array}$ & Cat\# M2670 \\
\hline $\begin{array}{l}\text { chemical } \\
\text { compound, } \\
\text { drug }\end{array}$ & $\mathrm{MgSO}_{4}$ & $\begin{array}{l}\text { SigmaMillipor } \\
\mathrm{e}\end{array}$ & Cat\# M1880 \\
\hline $\begin{array}{l}\text { chemical } \\
\text { compound, } \\
\text { drug }\end{array}$ & Glucose & $\begin{array}{l}\text { SigmaMillipor } \\
\mathrm{e}\end{array}$ & Cat\# G8270 \\
\hline $\begin{array}{l}\text { chemical } \\
\text { compound, } \\
\text { drug }\end{array}$ & $\mathrm{NaCl}$ & $\begin{array}{l}\text { SigmaMillipor } \\
\mathrm{e}\end{array}$ & Cat\# S7653 \\
\hline $\begin{array}{l}\text { chemical } \\
\text { compound, } \\
\text { drug }\end{array}$ & $\mathrm{NaHCO}_{3}$ & $\begin{array}{l}\text { SigmaMillipor } \\
\mathrm{e}\end{array}$ & Cat\# S6014 \\
\hline $\begin{array}{l}\text { chemical } \\
\text { compound, } \\
\text { drug }\end{array}$ & $\begin{array}{l}\text { Cesium } \\
\text { hydroxide }\end{array}$ & $\begin{array}{l}\text { SigmaMillipor } \\
\mathrm{e}\end{array}$ & Cat\# 23204 \\
\hline $\begin{array}{l}\text { chemical } \\
\text { compound, } \\
\text { drug }\end{array}$ & D-gluconic acid & $\begin{array}{l}\text { SigmaMillipor } \\
\mathrm{e}\end{array}$ & Cat\# G1951 \\
\hline $\begin{array}{l}\text { chemical } \\
\text { compound, } \\
\text { drug }\end{array}$ & EGTA & $\begin{array}{l}\text { SigmaMillipor } \\
\mathrm{e}\end{array}$ & Cat\# E4378 \\
\hline $\begin{array}{l}\text { chemical } \\
\text { compound, } \\
\text { drug }\end{array}$ & HEPES & SigmaMillipore & Cat\# H3375 \\
\hline $\begin{array}{l}\text { chemical } \\
\text { compound, } \\
\text { drug }\end{array}$ & $\begin{array}{l}\text { Potassium } \\
\text { gluconate }\end{array}$ & $\begin{array}{l}\text { SigmaMillipor } \\
\text { e }\end{array}$ & Cat\# G4500 \\
\hline
\end{tabular}




\begin{tabular}{|c|c|c|c|}
\hline $\begin{array}{l}\text { chemical } \\
\text { compound, } \\
\text { drug }\end{array}$ & MgATP & $\begin{array}{l}\text { SigmaMillipor } \\
\text { e }\end{array}$ & Cat\# A9187 \\
\hline $\begin{array}{l}\text { chemical } \\
\text { compound, } \\
\text { drug }\end{array}$ & $\mathrm{Na}_{3} \mathrm{GTP}$ & $\begin{array}{l}\text { SigmaMillipor } \\
\text { e }\end{array}$ & Cat\# G0635 \\
\hline $\begin{array}{l}\text { chemical } \\
\text { compound, } \\
\text { drug }\end{array}$ & NMDG & $\begin{array}{l}\text { SigmaMillipor } \\
\text { e }\end{array}$ & Cat\# M2004 \\
\hline $\begin{array}{l}\text { chemical } \\
\text { compound, } \\
\text { drug }\end{array}$ & $\begin{array}{l}\text { Sodium } \\
\text { ascorbate }\end{array}$ & $\begin{array}{l}\text { SigmaMillipor } \\
\mathrm{e}\end{array}$ & Cat\# A4034 \\
\hline $\begin{array}{l}\text { chemical } \\
\text { compound, } \\
\text { drug }\end{array}$ & Thiourea & $\begin{array}{l}\text { SigmaMillipor } \\
\text { e }\end{array}$ & Cat\# T8656 \\
\hline $\begin{array}{l}\text { chemical } \\
\text { compound, } \\
\text { drug }\end{array}$ & Sodium pyruvate & $\begin{array}{l}\text { SigmaMillipor } \\
\text { e }\end{array}$ & Cat\# P2256 \\
\hline $\begin{array}{l}\text { chemical } \\
\text { compound, } \\
\text { drug }\end{array}$ & $\mathrm{KMeSO}_{4}$ & $\begin{array}{l}\text { SigmaMillipor } \\
\text { e }\end{array}$ & Cat\# 83000 \\
\hline $\begin{array}{l}\text { chemical } \\
\text { compound, } \\
\text { drug }\end{array}$ & $\mathrm{Na}_{2} \mathrm{ATP}$ & $\begin{array}{l}\text { SigmaMillipor } \\
\mathrm{e}\end{array}$ & Cat\# A2383 \\
\hline $\begin{array}{l}\text { chemical } \\
\text { compound, } \\
\text { drug }\end{array}$ & NaGTP & $\begin{array}{l}\text { SigmaMillipor } \\
\text { e }\end{array}$ & Cat\# 51120 \\
\hline $\begin{array}{l}\text { chemical } \\
\text { compound, } \\
\text { drug }\end{array}$ & $\begin{array}{l}\text { Sodium } \\
\text { Phosphocreatine }\end{array}$ & $\begin{array}{l}\text { SigmaMillipor } \\
\text { e }\end{array}$ & Cat\# P7936 \\
\hline $\begin{array}{l}\text { chemical } \\
\text { compound, } \\
\text { drug }\end{array}$ & $\mathrm{NH}_{4} \mathrm{Cl}$ & $\begin{array}{l}\text { SigmaMillipor } \\
\text { e }\end{array}$ & Cat\# A9434 \\
\hline $\begin{array}{l}\text { chemical } \\
\text { compound, } \\
\text { drug }\end{array}$ & $\mathrm{KOH}$ & EMD Millipore & Cat\# 109108 \\
\hline
\end{tabular}




\begin{tabular}{|c|c|c|c|c|}
\hline $\begin{array}{l}\text { chemical } \\
\text { compound, } \\
\text { drug }\end{array}$ & $\mathrm{HCl}$ & $\begin{array}{l}\text { Fisher } \\
\text { Chemical }\end{array}$ & Cat\# SA49 & \\
\hline $\begin{array}{l}\text { software, } \\
\text { algorithm }\end{array}$ & IgorPro7 & Wavemetrics & & $\begin{array}{l}\text { https://www. } \\
\text { wavemetrics. } \\
\text { com/ }\end{array}$ \\
\hline $\begin{array}{l}\text { software, } \\
\text { algorithm }\end{array}$ & Origin Pro 9 & Origin Lab & & $\frac{\text { https://www. }}{\text { originlab.com }}$ \\
\hline $\begin{array}{l}\text { software, } \\
\text { algorithm }\end{array}$ & ImageJ & ImageJ & & $\begin{array}{l}\text { http://imagej. } \\
\text { net/ } \\
\text { Welcome }\end{array}$ \\
\hline $\begin{array}{l}\text { software, } \\
\text { algorithm }\end{array}$ & Multiclamp 700B & $\begin{array}{l}\text { Molecular } \\
\text { Devices }\end{array}$ & & $\begin{array}{l}\text { https://www. } \\
\text { molecular } \\
\text { devices.com/ }\end{array}$ \\
\hline $\begin{array}{l}\text { software, } \\
\text { algorithm }\end{array}$ & Prairie View 5.4 & Bruker Corp. & & $\begin{array}{l}\text { https://www.pv } \\
\text { update } \\
\text {.blogspot.com/ }\end{array}$ \\
\hline
\end{tabular}



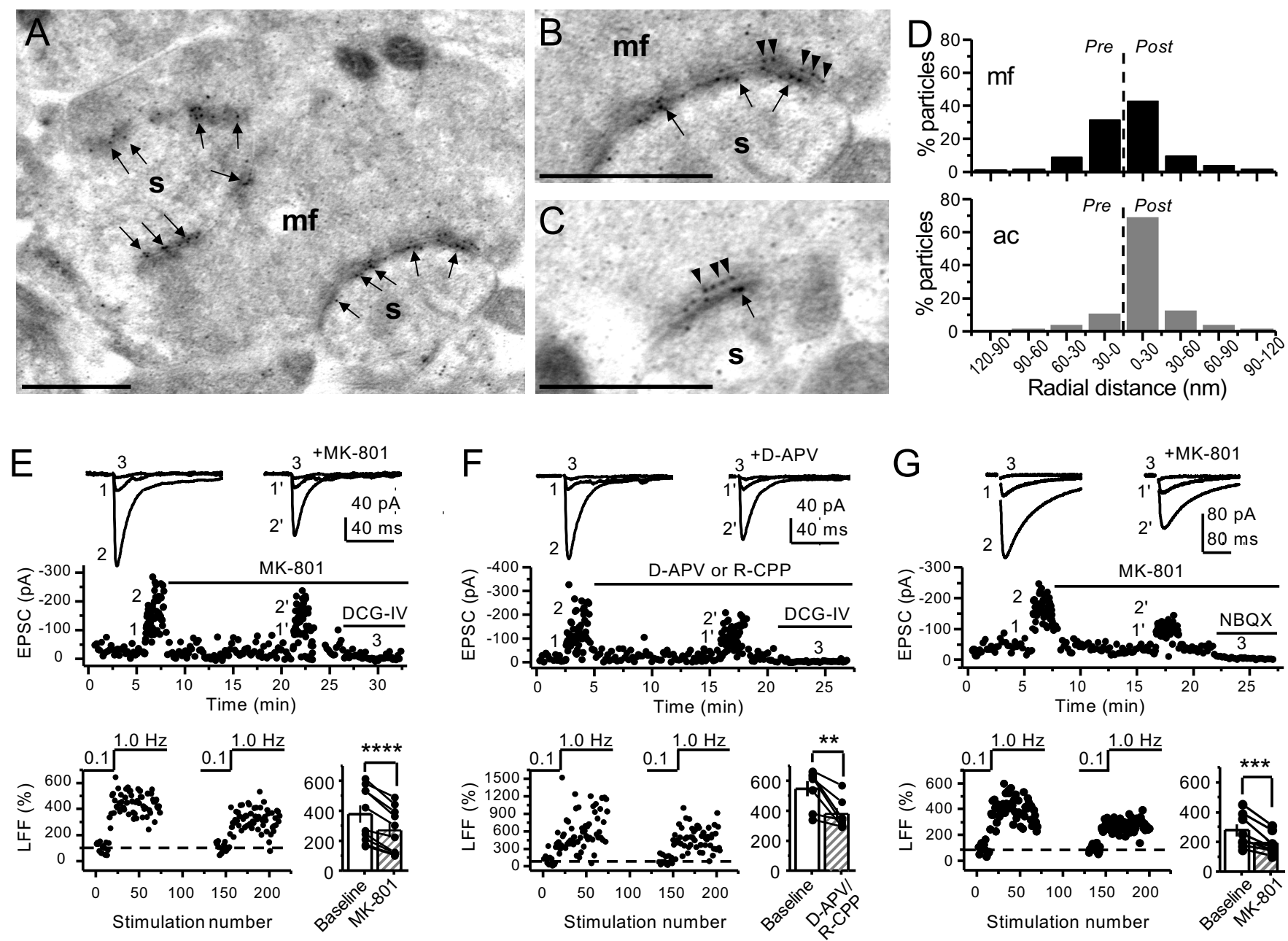

Figure 1. Anatomical and functional evidence for preNMDARs at mossy fiber synapses. 
bioRxiv preprint doi: https://doi.org/10.1101/2021.01.21.427714; this version posted May 11, 2021. The copyright holder for this preprint (which

was not certified by peer review) is the author/funder, who has granted bioRxiv a license to display the preprint in perpetuity. It is made available under aCC-BY 4.0 International license.
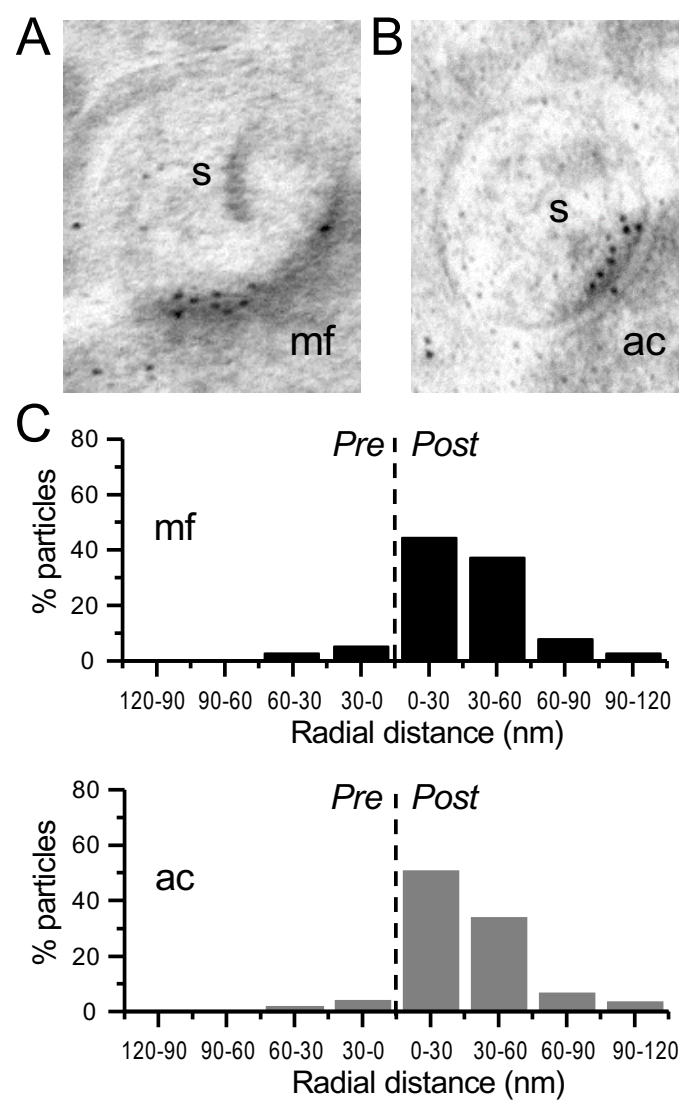

Figure 1-figure supplement 1 
bioRxiv preprint doi: https://doi.org/10.1101/2021.01.21.427714; this version posted May 11, 2021. The copyright holder for this preprint (which

was not certified by peer review) is the author/funder, who has granted bioRxiv a license to display the preprint in perpetuity. It is made available under aCC-BY 4.0 International license.

A
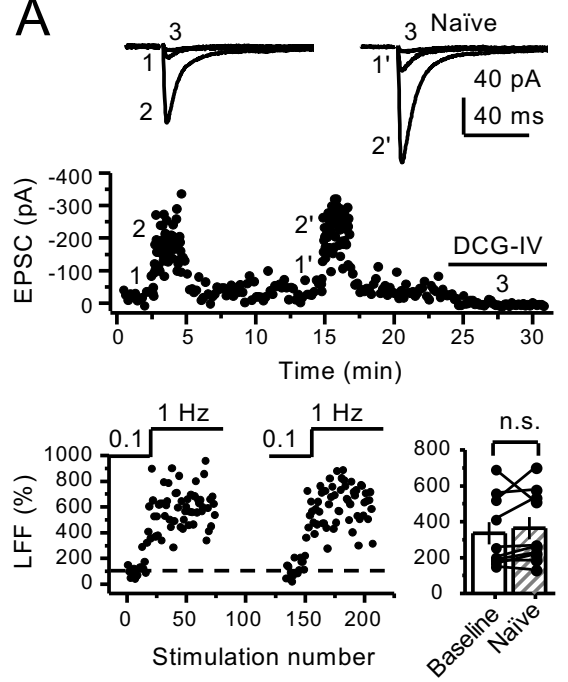

B
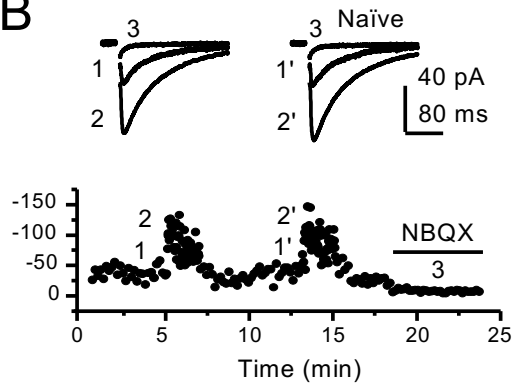

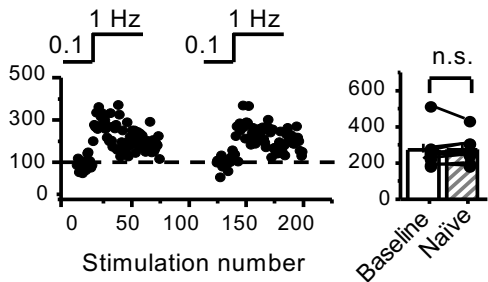

Figure 1-figure supplement 2 
bioRxiv preprint doi: https://doi.org/10.1101/2021.01.21.427714; this version posted May 11, 2021. The copyright holder for this preprint (which

was not certified by peer review) is the author/funder, who has granted bioRxiv a license to display the preprint in perpetuity. It is made available under aCC-BY 4.0 International license.
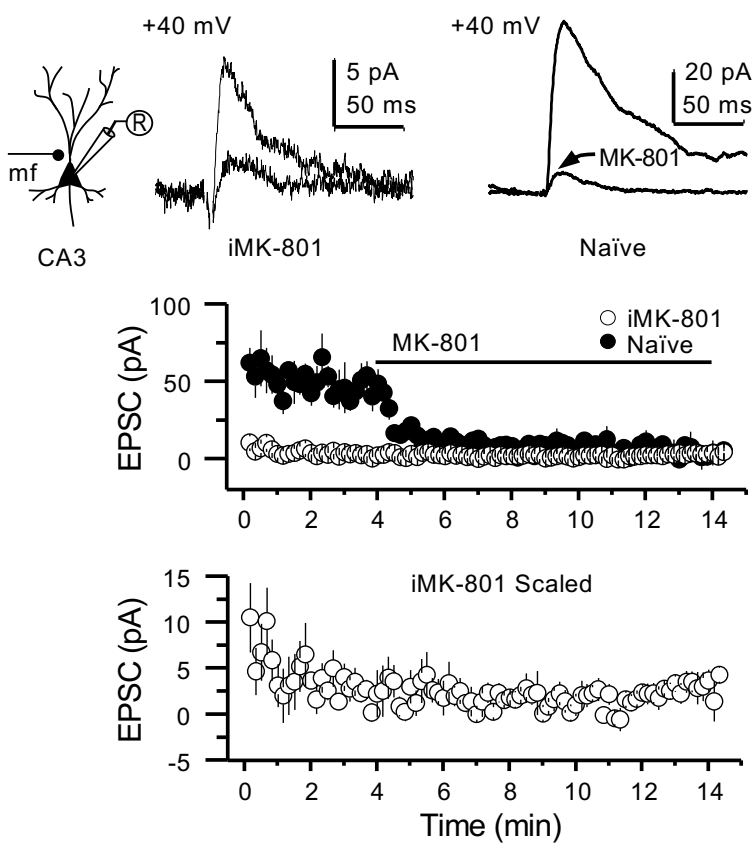

Figure 1-figure supplement 3 

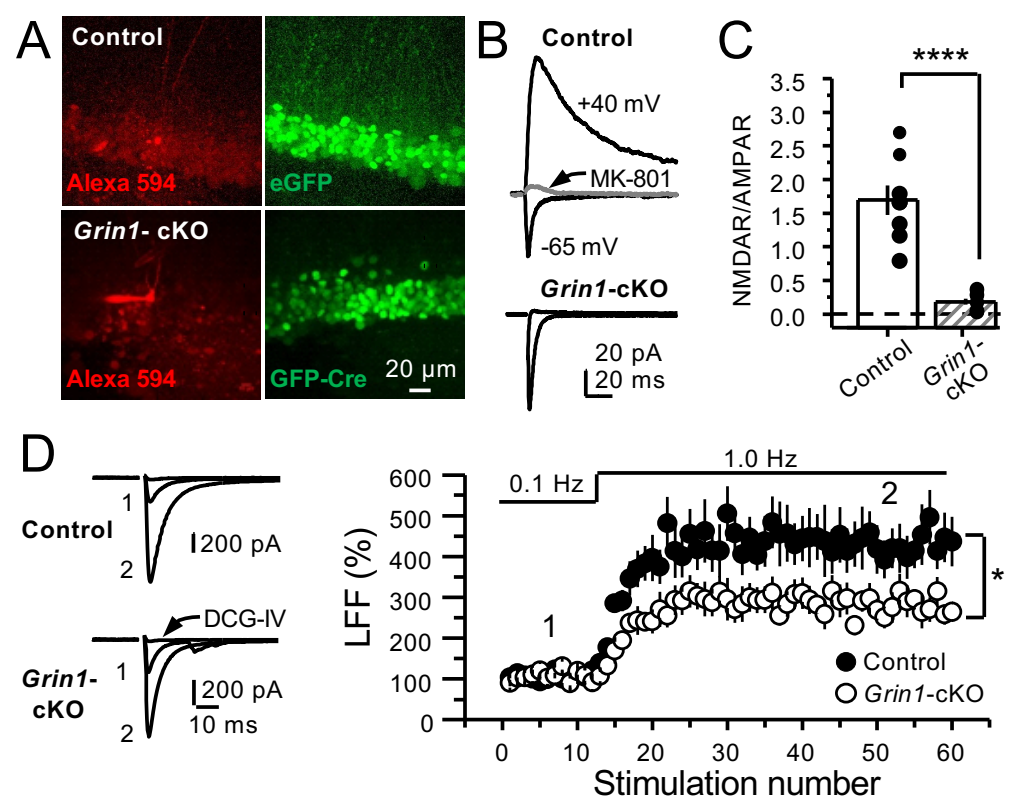

Figure 2. GluN1 deletion from granule cells reduces mf-CA3 facilitation. 

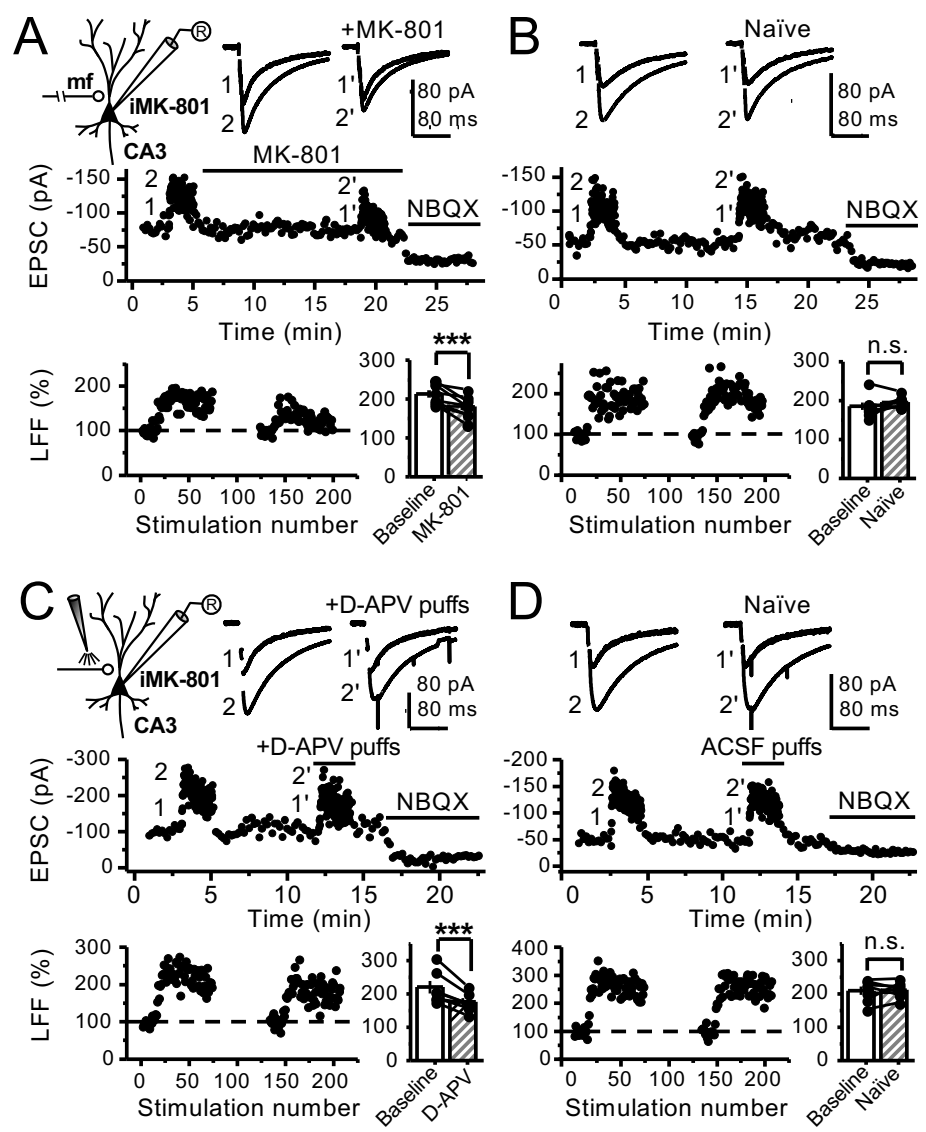

Figure 3. Reduced facilitation by NMDAR antagonism is independent of the GC somatodendritic compartment. 
bioRxiv preprint doi: https://doi.org/10.1101/2021.01.21.427714; this version posted May 11, 2021. The copyright holder for this preprint (which

was not certified by peer review) is the author/funder, who has granted bioRxiv a license to display the preprint in perpetuity. It is made available under aCC-BY 4.0 International license.

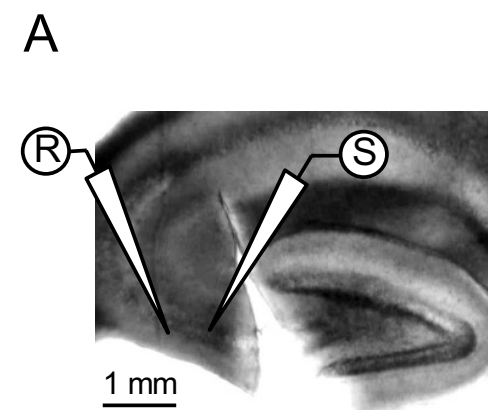

B

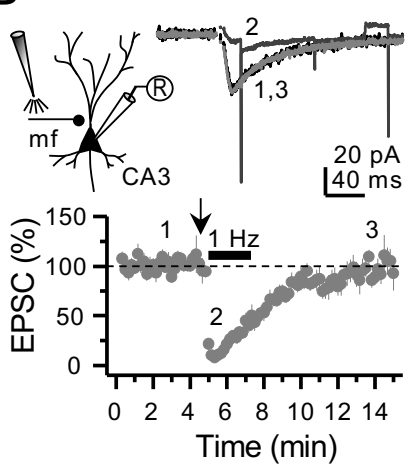

C

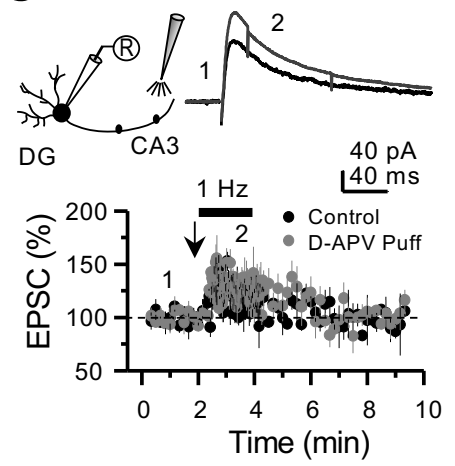

Figure 3-figure supplement 1 


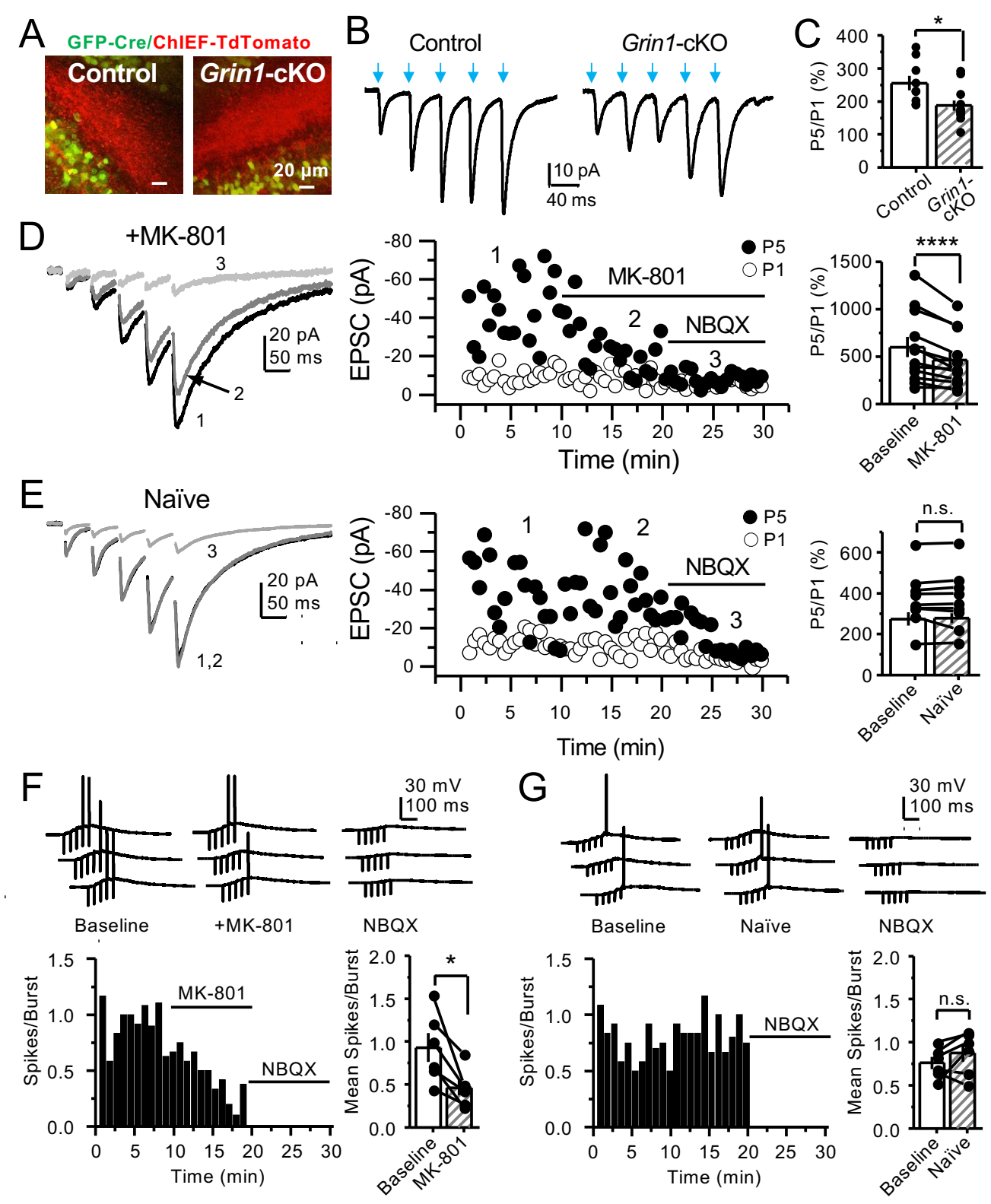

Figure 4. PreNMDARs contribute significantly to burst-induced facilitation and spike transfer. 


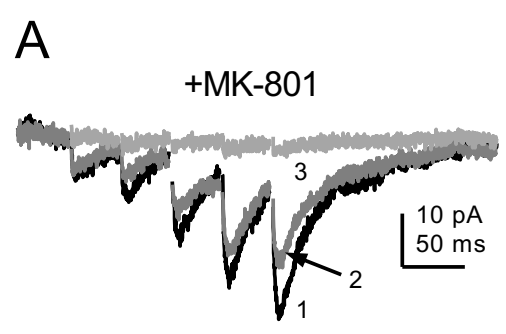

B

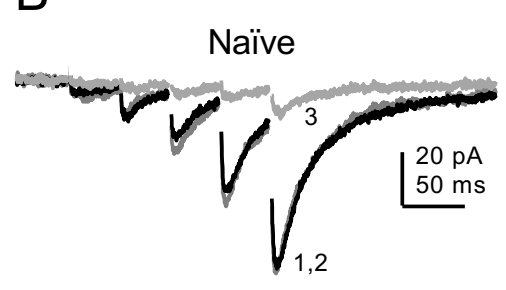

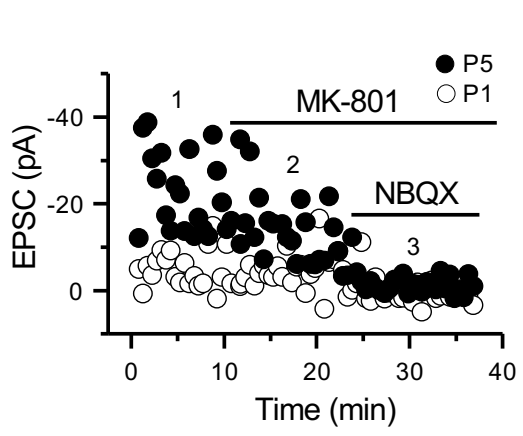
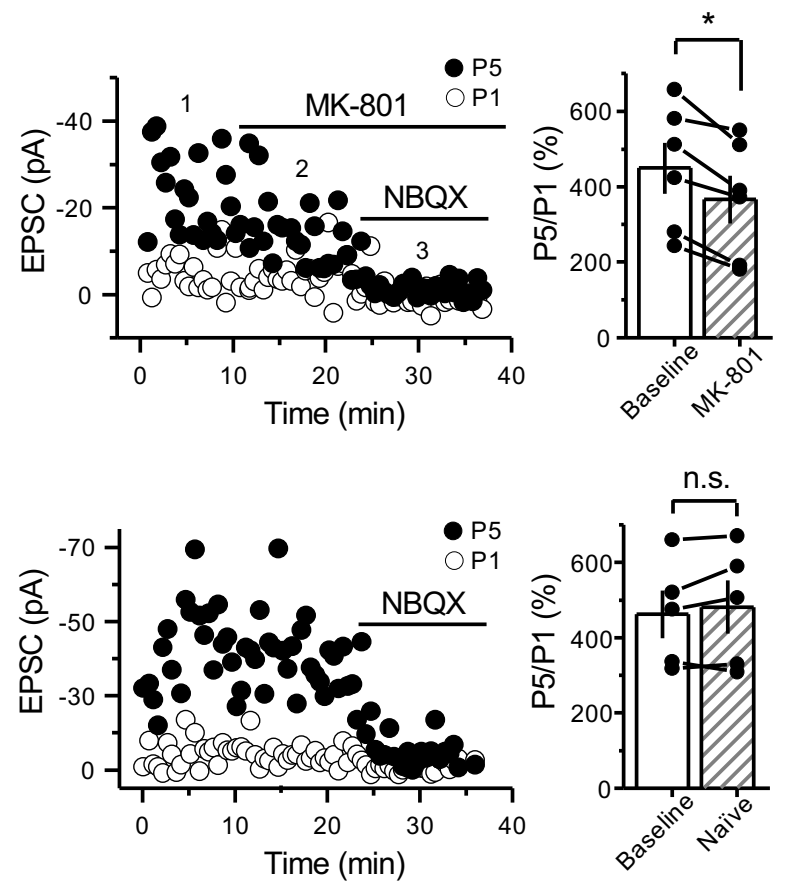

Figure 4-figure supplement 1 

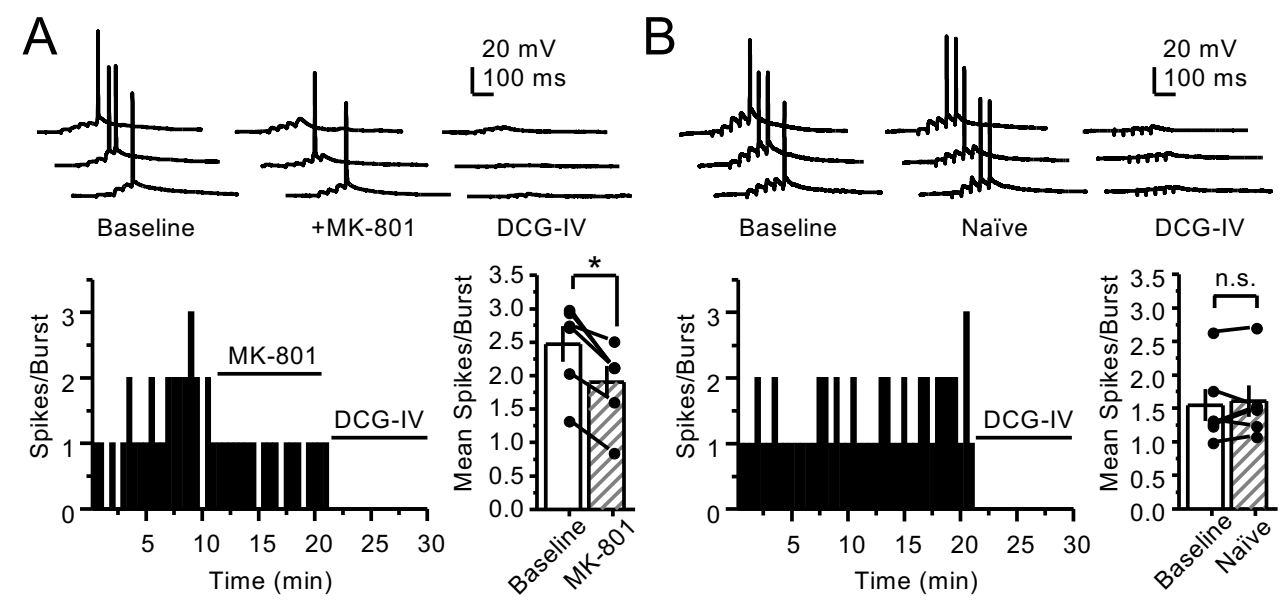

Figure 4-figure supplement 2 


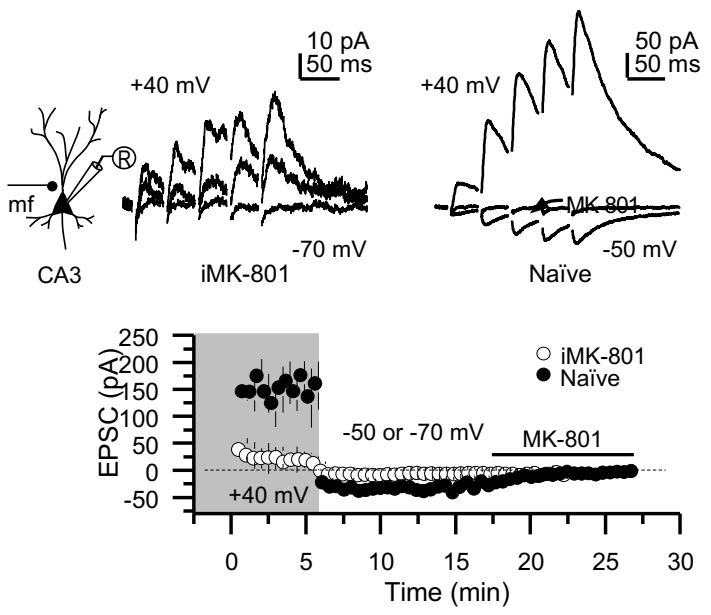

Figure 4-figure supplement 3 
A

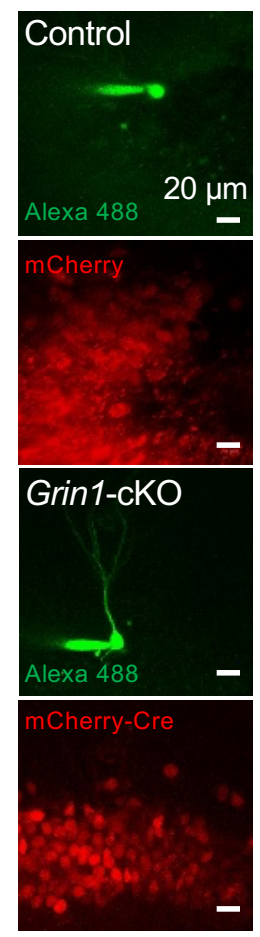

B

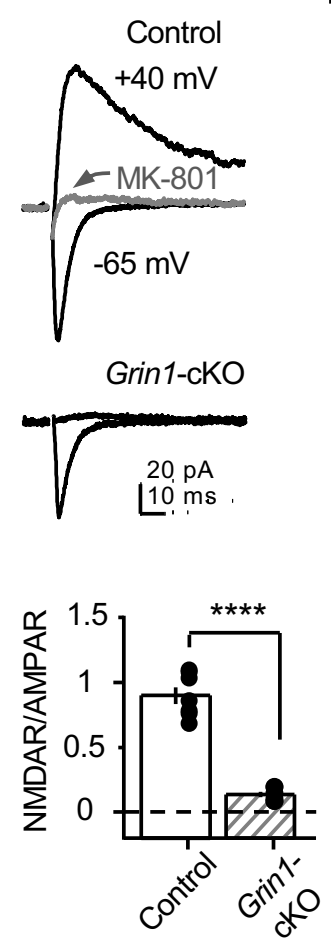

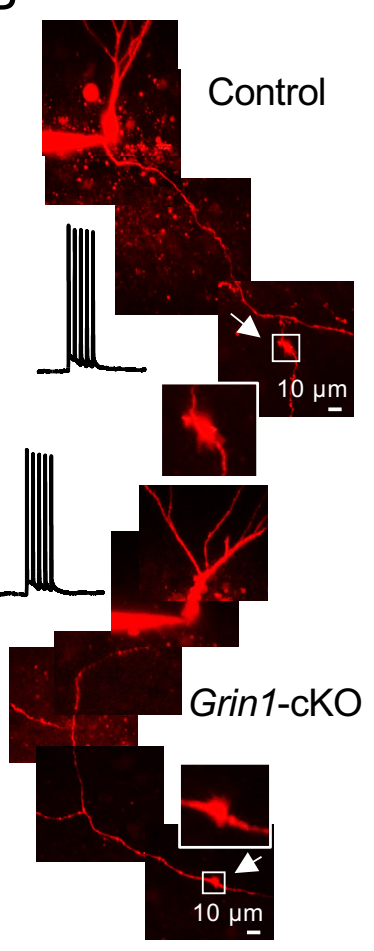

C
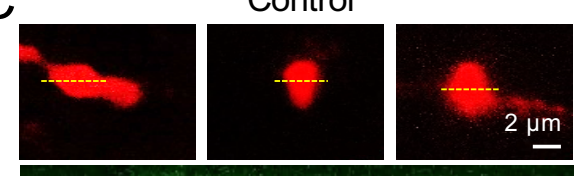

Fluo-5F
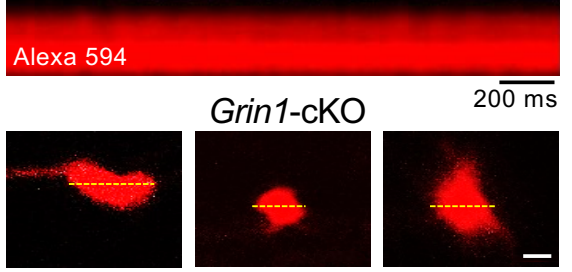

Fluo-5F

Alexa 594
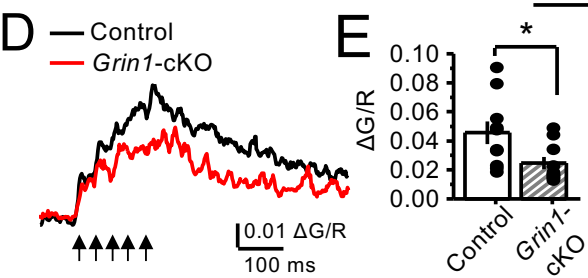

Figure 5. preNMDARs contribute to presynaptic $\mathrm{Ca}^{2+}$ rise. 
A

B
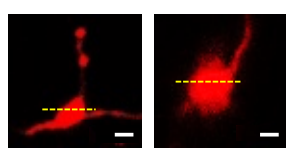

Baseline

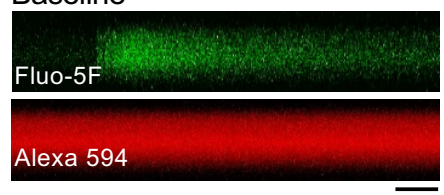

$+\mathrm{D}-\mathrm{APV}$

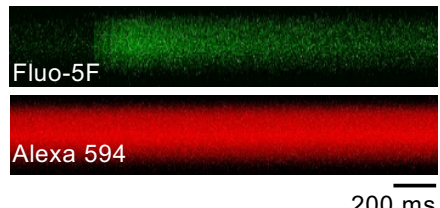

C

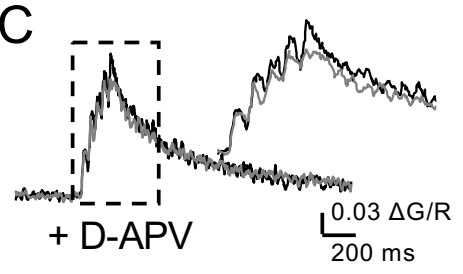

$\mathrm{D}$

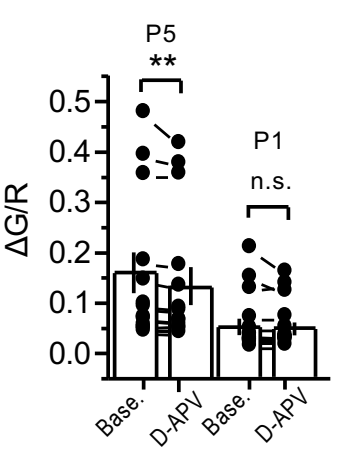

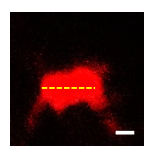
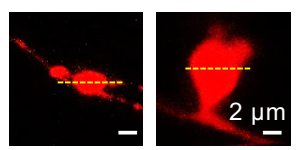

Baseline

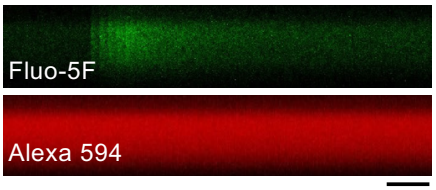

Naïve
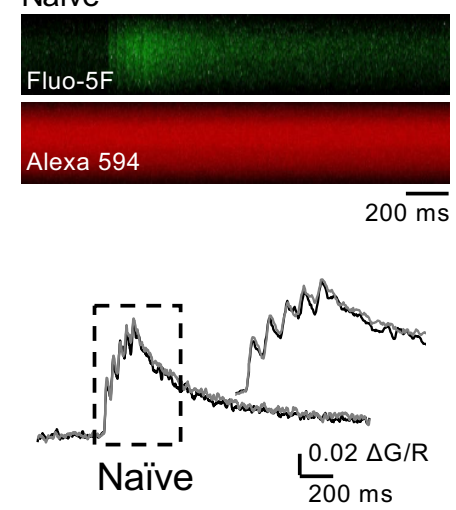

E

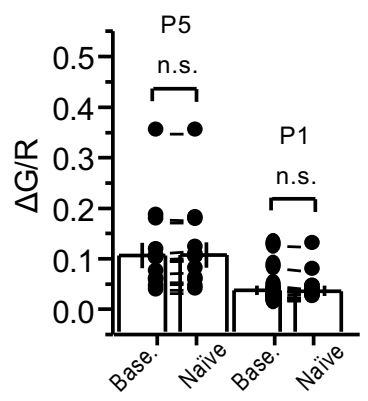

Figure 5-figure supplement 1 
A
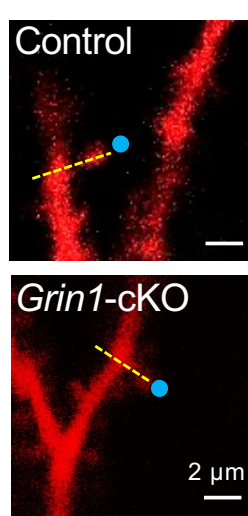

B

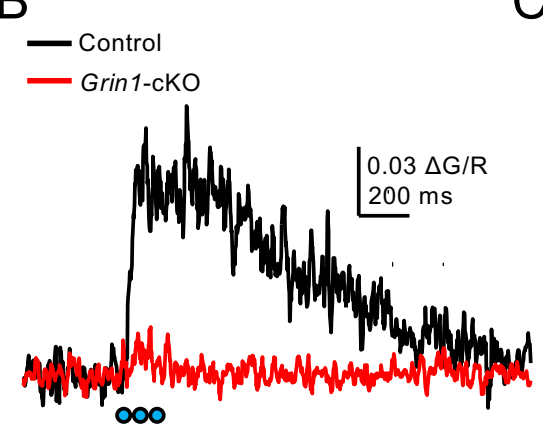

GC dendritic spine

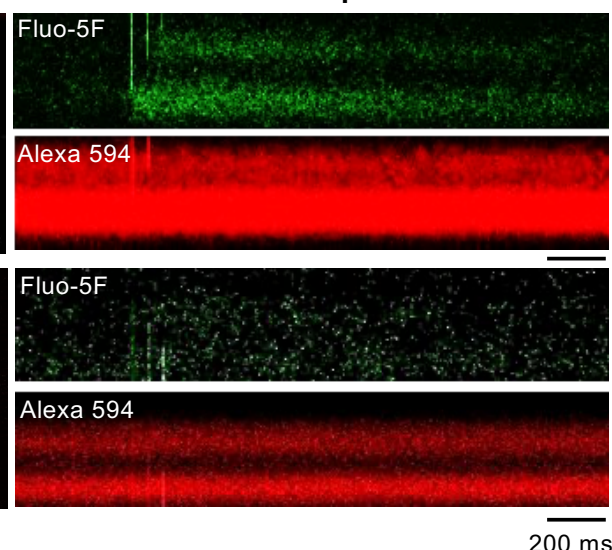

C

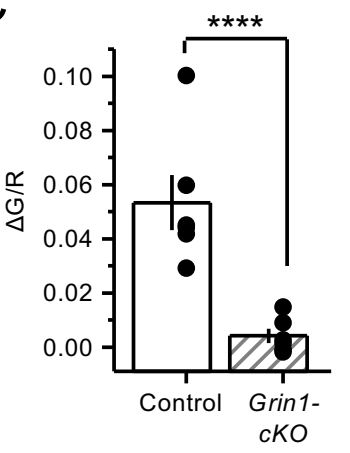

Mossy fiber bouton
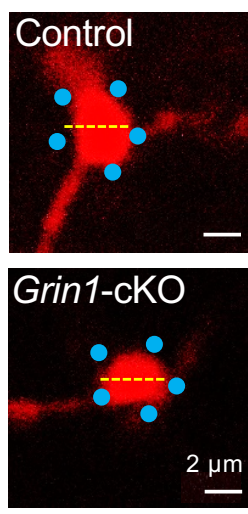

$\mathrm{D}$

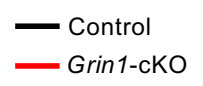

Grin1-ckO

$0.01 \Delta \mathrm{G} / \mathrm{R}$ $200 \mathrm{~ms}$

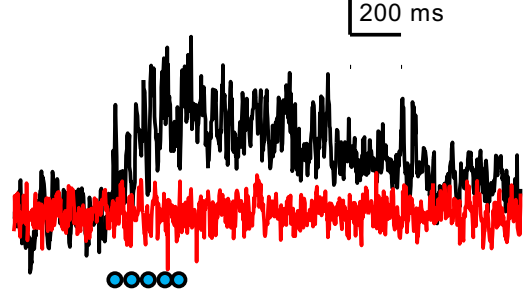

E

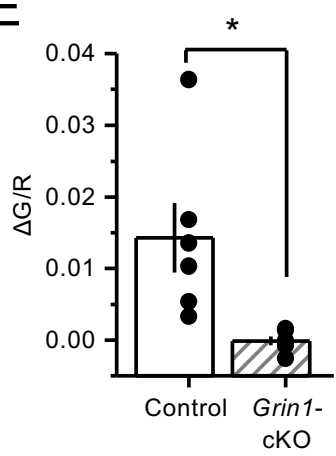

Figure 6. Uncaging glutamate induces $\mathrm{Ca}^{2+}$ rise mossy fiber boutons. 
bioRxiv preprint doi: https://doi.org/10.1101/2021.01.21.427714; this version posted May 11, 2021. The copyright holder for this preprint (which was not certified by peer review) is the author/funder, who has granted bioRxiv a license to display the preprint in perpetuity. It is made available under aCC-BY 4.0 International license.

A
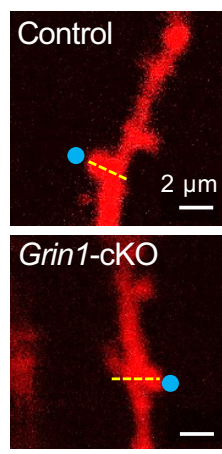

B
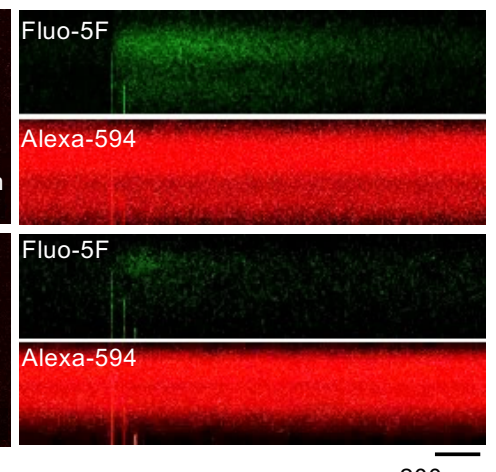

$200 \overline{\mathrm{ms}}$

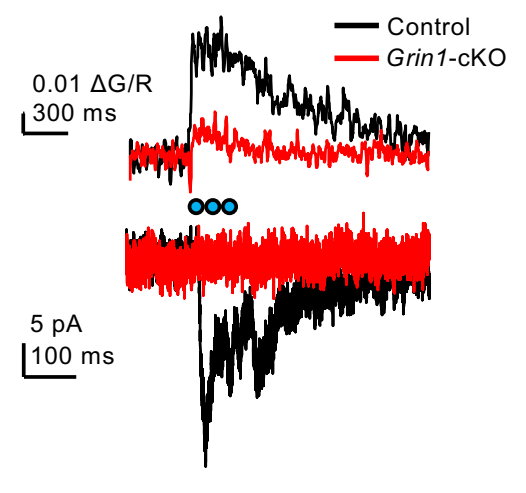

C

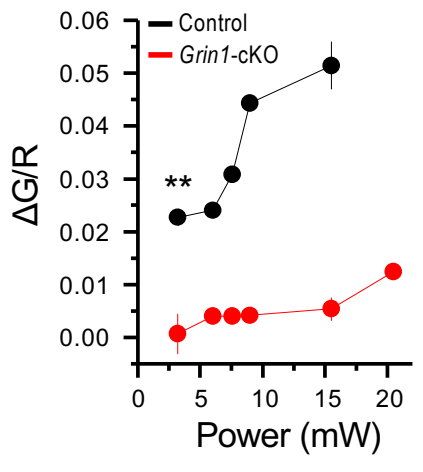

Figure 6-figure supplement 1 
bioRxiv preprint doi: https://doi.org/10.1101/2021.01.21.427714; this version posted May 11, 2021. The copyright holder for this preprint (which

was not certified by peer review) is the author/funder, who has granted bioRxiv a license to display the preprint in perpetuity. It is made available under aCC-BY 4.0 International license.

A

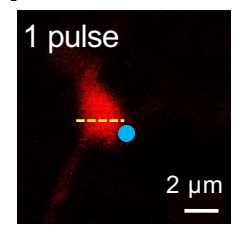

5 pulses

0

0
B

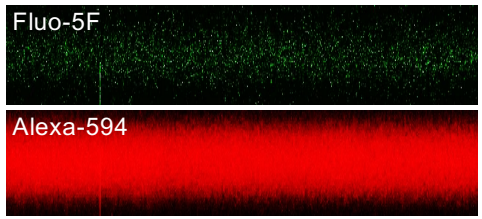

Fluo-5F

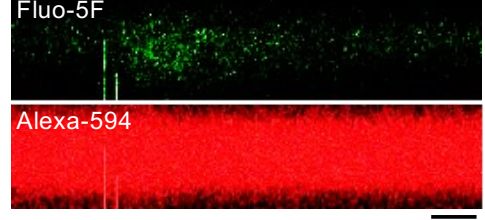

$200 \overline{\mathrm{ms}}$

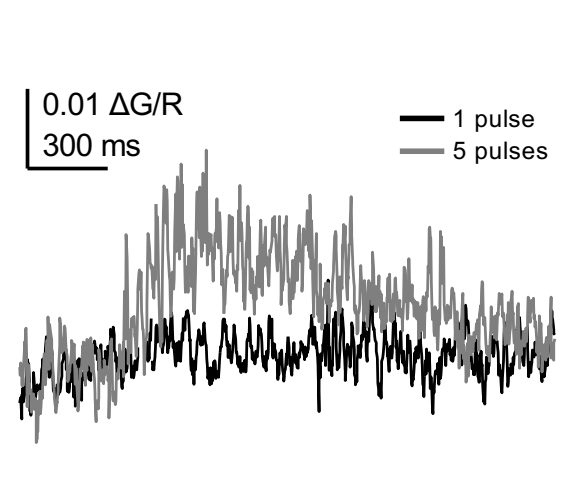

C

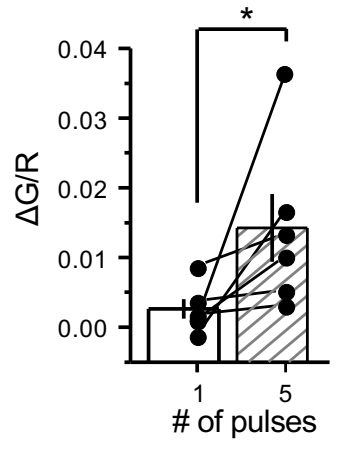

Figure 6-figure supplement 2 


\section{A Mossy fiber bouton \\ Baseline}
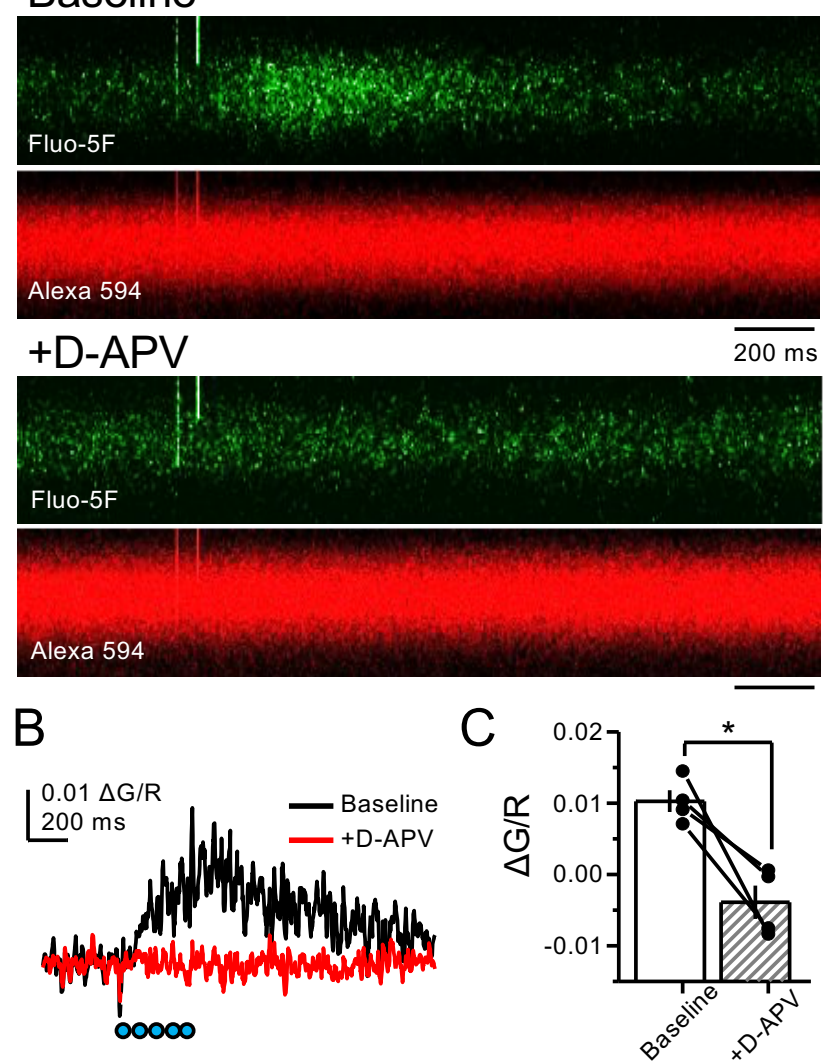

Figure 6-figure supplement 3 

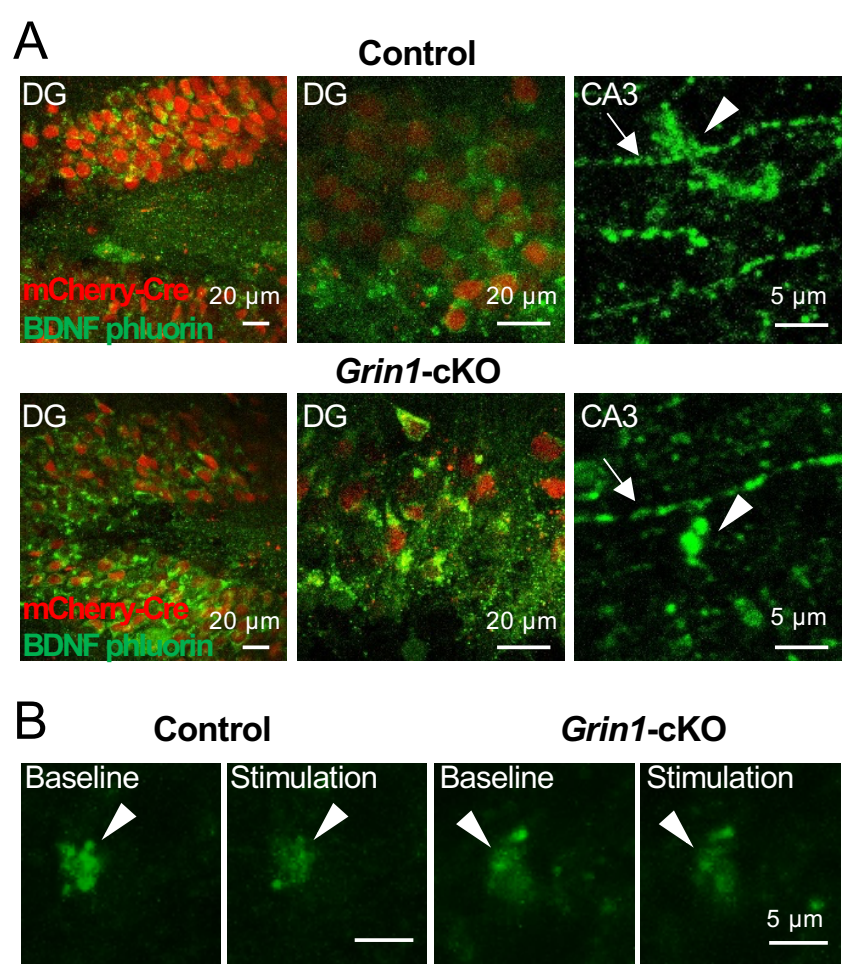

Control

\section{Grin1-cKO}
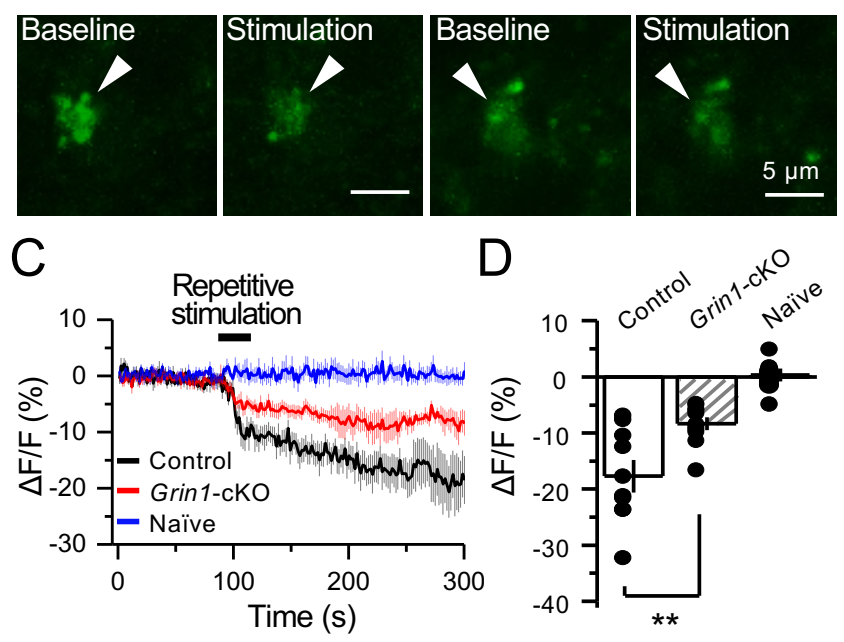

Figure 7. preNMDARs contribute significantly to BDNF release following repetitive activity. 
bioRxiv preprint doi: https://doi.org/10.1101/2021.01.21.427714; this version posted May 11, 2021. The copyright holder for this preprint (which was not certified by peer review) is the author/funder, who has granted bioRxiv a license to display the preprint in perpetuity. It is made available under aCC-BY 4.0 International license.

\section{A Control}
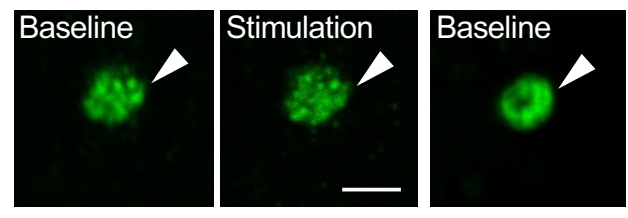

Grin1-cKO

B

5 pulses @ $100 \mathrm{~Hz}$

$\mathrm{HH} \times 50 @ 2 \mathrm{~Hz}$
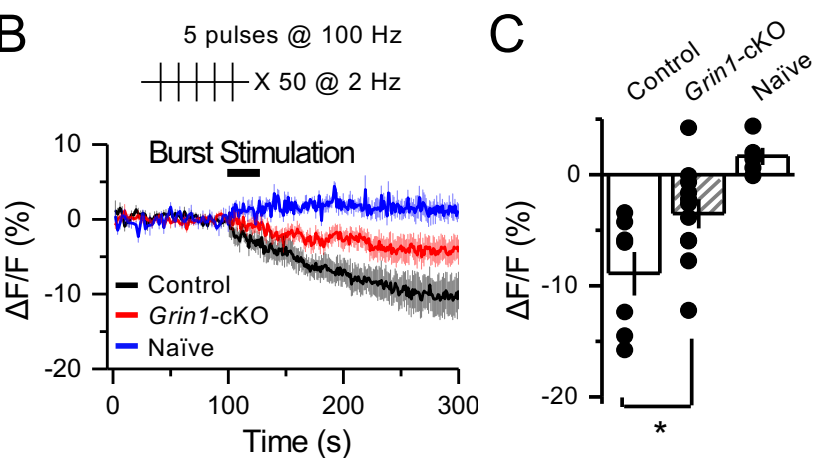

Figure 7-figure supplement 1 


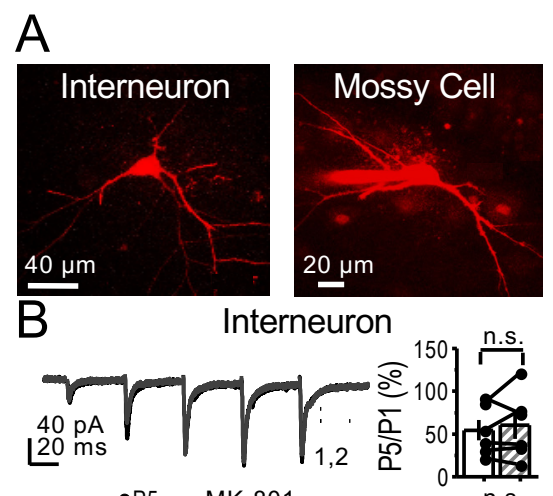

C Mossy Cell
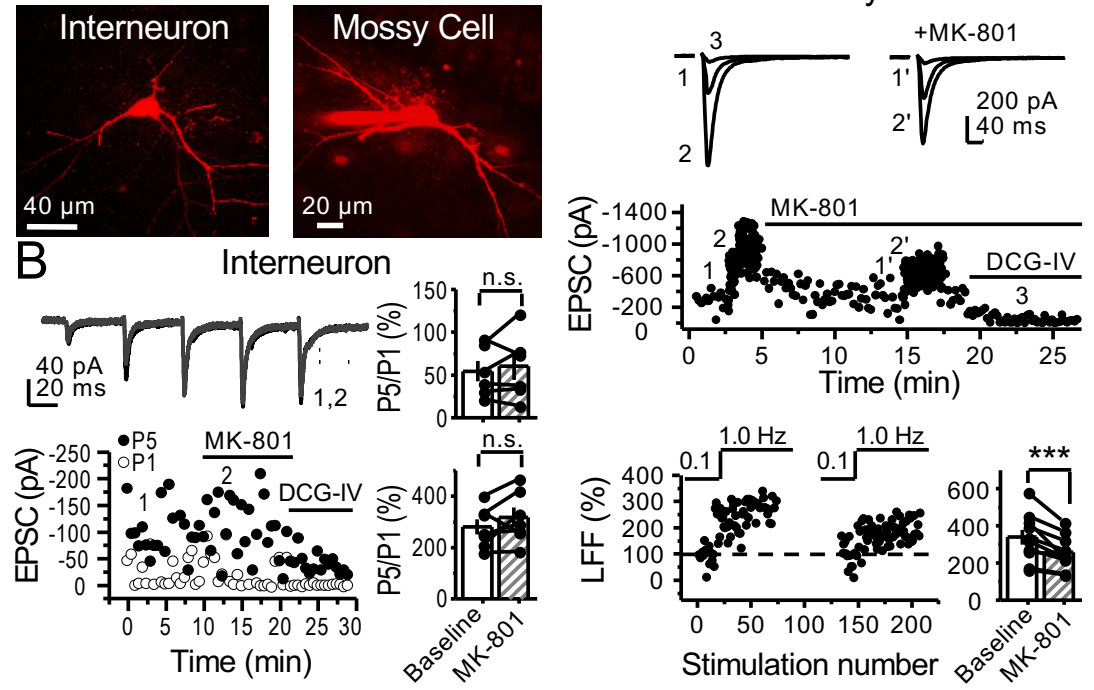

Figure 8. preNMDARs contribute to synaptic facilitation of mossy fiber inputs onto mossy cells but not onto CA3 inhibitory interneurons. 

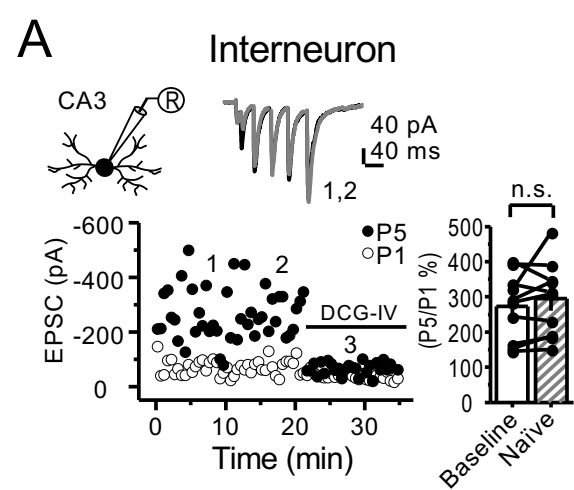

B
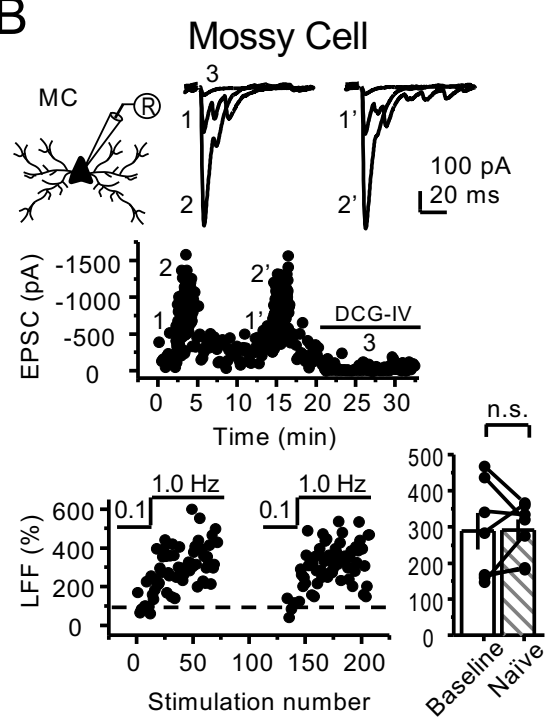

Figure 8-figure supplement 1 